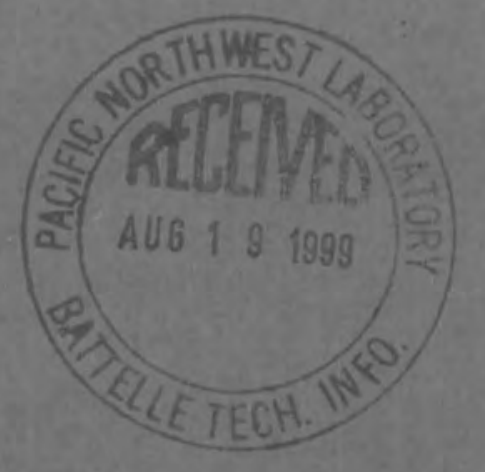

$\frac{\text { PNL-3198 }}{\text { UC-70 }}$

\title{
Durability of Metals From Archaeological Objects, Metal Meteorites, and Native Metals
}
A. B. Johnson, Jr.
B. Francis

January 1980

Prepared for the U.S. Department of Energy under Contract EY-76-C-06-1830

Pacific Northwest Laboratory Operated for the U.S. Department of Energy by Battelle Memorial Institute 


\title{
NOTICE
}

This report was prepared as an account of work sponsored by the United States Government. Neither the United States nor the Department of Energy, nor any of their employees, nor any of their contractors, subcontractors, or their employees, makes any warranty, express or implied, or assumes any legal liability or responsibility for the accuracy, completeness or usefulness of any information, apparatus, product or process disclosed, or represents that its use would not infringe privately owned rights.

The views, opinions and conclusions contained in this report are those of the contractor and do not necessarily represent those of the United States Government or the United States Department of Energy.

\author{
PACIFIC NORTHWEST LABORATORY \\ operated by \\ BATTELLE \\ for the . \\ UNITED STATES DEPARTMENT OF ENERGY \\ Under Contract EY-76-C-06-1830
}
Printed in the United States of America
Available from
National Technical Information Service
United States Department of Commerce
5285 Port Royal Road
Springfield, Virginia 22151

Price: Printed Copy s

$\therefore$ Microfiche $\$ 3,00$

NTIS
-Pages Selling Price

$001-025 \quad \$ 4.00$

$026-050 \quad \$ 4.50$

$051-075 \quad \$ 5.25$

076-100 $\quad \$ 6.00$

101-125 $\quad \$ 6.50$

$126-150 \quad 57.25$

$151-175 \quad \$ 8.00$

$176-200 \quad \$ 9.00$

201-225 $\$ 9.25$

$226-250 \quad \$ 9.50$

$251-275 \quad 510.75$

$276-300 \quad \$ 11.00$ 


\section{0}

DURABILITY OF METALS FROM

ARCHAEOLOGICAL OBJECTS, METAL

METEORITES, AND NATIVE METALS

A. B. Johnson, Jr.

B. Francis

January 1980

Prepared for

the U.S. Department of Energy

under Contract EY-76-C-06-1830

Pacific Northwest Laboratory

Richland, Washington 99352 


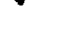

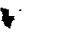




\section{SUMMARY AND CONCLUSIONS}

Metal durability is an important consideration in the multi-barrier nuclear waste storage concept. Several metals have shown impressive durability over centuries and millenia in several environments. This study summarizes the ancient metals, the environments, and factors which appear to have contributed to metal longevity. The ancient metals include archaeological objects, metal meteorites, and native metals.

The seven metals of antiquity are gold, silver, copper, lead, iron, tin, and mercury. Archaeological and radiochemical dating suggest that human use of metals began in the period 6000 to $7000 \mathrm{BC}$. Thousands of metallic artifacts exist, some still in good repair after several millenia. They have been found in caves, tombs, graves, shipwrecks, and various other environments above and below ground. Gold is clearly the most durable, but many objects fashioned from silver, copper, bronze, iron, lead, and tin have survived for several thousand years. Dry environments, such as tombs, appear to be optimum for metal preservation, but some metals have survived in shipwrecks for over a thousand years.

The metal meteorites are iron-base alloys with 5 to $60 \mathrm{wt} \%$ nickel and minor amounts of cobalt, phosphorous, and sulfur. Approximately 530 metal meteorites have been identified. Over half show minimal weathering. Some meteoritic masses with ages estimated to be 5,000 to 20,000 years have weathered very little. Other masses from the same meteorites are in advanced stages of weathering. Those which survived best fell in dry locales, were not buried in the ground, were largely free of aggressive species such as chlorides, and may have been protected by oxides formed by high-temperature reactions with the earth's atmosphere. First hand examination of corrosion on several meteorites is discussed.

Native metals are natural metallic ores. Gold, silver, copper, and mercury occur as native metals in commercial quantities. Other metals occur but in relatively small amounts. On a tonnage basis, copper has been the most significant native metal. Approximately five million tonnes were mined from native copper deposits in Michigan. 
Copper masses from the Michigan deposits were transported by the Pleistocene glaciers. We have examined two masses of this so-called "float" copper. Areas on the copper surfaces which appear to represent glacial abrasion show minimal corrosion. The last glaciers receded about 8,000 years ago, so the abrasion is at least that old.

The foregoing examples of impressive multi-century metal durability provide a useful baseline for extrapolations and offer valuable insights to optimum storage environments. However, they differ from nuclear waste canister environments: the temperatures are lower and radiation has been absent.

In Iiquidous environments, effects of these two factors are difficult to assess and extrapolate. In an engineered dry environment, the temperature/ radiation effects appear much more amenable to assessment and appear less likely to be problematic.

Dry cooling tower technology has demonstrated that in pollution-free moist environments, metals fare better at temperatures above than below the dewpoint. Thus, in moderate temperature regimes, elevated temperatures may be useful rather than detrimental for exposures of metal to air.

In liquid environments, relatively complex radiolysis reactions can occur, particularly where multiple species are present. A dry environment largely obviates radiolysis effects.

The major conclusions of this study are:

- that several metals have shown impressive multi-century and multi-millenia durability in natural environments

- that dry or mildly moist environments have been optimum for metal preservation

- that dry or mildly moist environments appear most amenable to data extrapolation and to preservation of nuclear waste containers. 


\section{ACKNOWLEDGMENTS}

The authors are grateful to the following for significant contributions to the report. For discussions of archaeological metal objects: Dr. M. S. Tite and Dr. W. A. Oddy of the British Museum, London; Madame M. Hours and Mr. Lahanier of the Louvre research staff, Paris; Dr. T. Chase and Dr. R. M. Organ, Smithsonian Institution, Washington, DC; and Dr. M. F. Kaplan, The Analytical Sciences Corp., Reading, MA.

For discussions of metal meteorites: Dr. V. F. Buchwald, Technical University-Denmark, Lyngby, Denmark; Dr. E. 01sen, Field Museum, Chicago (also provided meteorite specimens); Prof. C. B. Moore, Arizona State University, Tucson, AZ, Dr. R. Clark and B. Mason, Smithsonian Institution.

For discussion of native metals: Prof. R. E. Brown, Pasco, WA; Dr. 0. J. du Temple, Hinsdale, IL; Ms. J. P. Kemp and Prof. B. M. Hami1, Michigan Technological University, Houghton, MI; Dr. Emi 1 Veakis, Brookhaven National Laboratory, Upton, NY. Mr. Richard Whiteman of Hancock, MI, supplied float copper specimens.

Drs. R. E. Westerman, R. L. Dillon, and M. J. Zamorski commented on the draft. R. H. Beauchamp ${ }^{(a)}$ provided metallography of meteorite and native copper specimens; H. E. Kjarmo ${ }^{(a)}$ provided scanning electron microscopy and microprobe analyses of meteorite specimens; H. E. Kissinger $(a)$ provided X-ray diffraction analyses of deposits on meteorite and native copper.

Mr. M. J. Bussert and Ms. L. Pedersen assisted with preparation of the draft.

(a) Materials Department, Pacific Northwest Laboratory. 
i. v 


\section{CONTENTS}

SUMMARY AND CONCLUSIONS

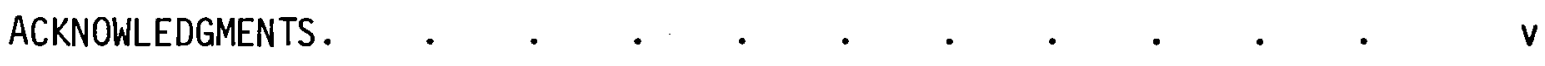

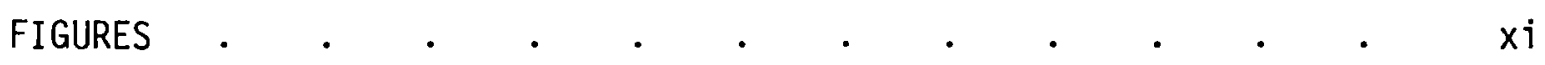

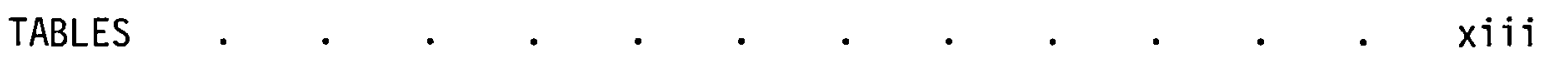

T.0 INTRODUCTION

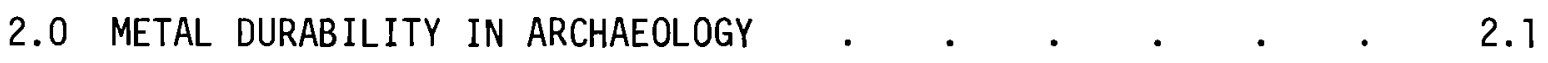

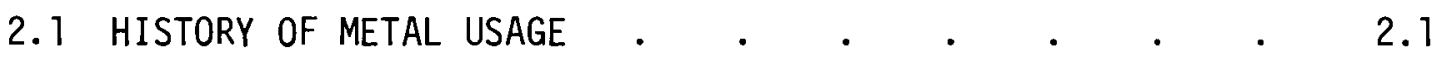

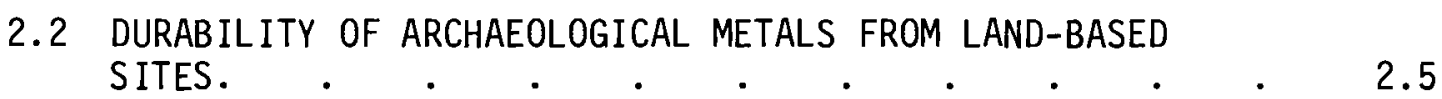

2.2 .1 Gold $\quad . \quad$. $\quad . \quad$. $\quad . \quad . \quad . \quad . \quad . \quad 2.8$

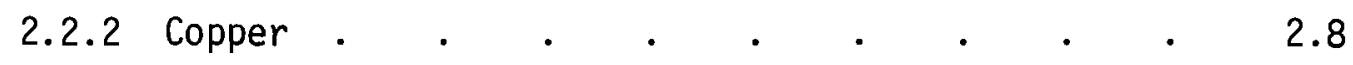

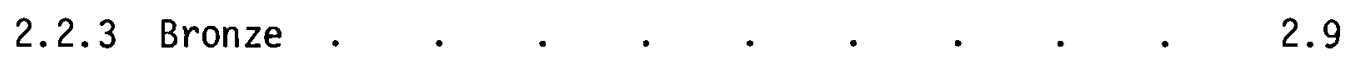

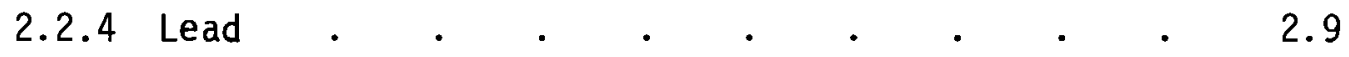

2.2 .5 Iron $\quad . \quad . \quad . \quad . \quad . \quad . \quad . \quad . \quad 2.10$

$2.2 .6 \operatorname{Tin} \quad . \quad . \quad . \quad . \quad . \quad . \quad . \quad . \quad 2.10$

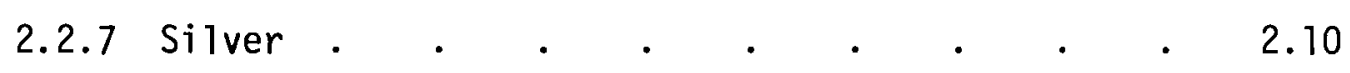

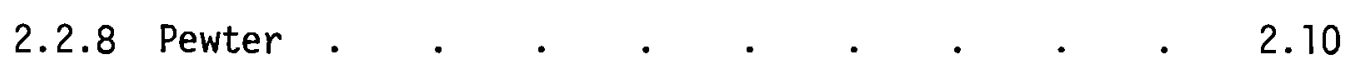

2.3 DURABILITY OF METALS IN SEA WATER $\quad . \quad$. $\quad$ • 2.7

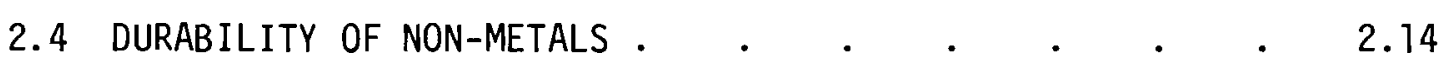

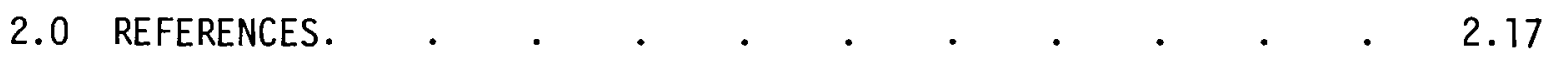

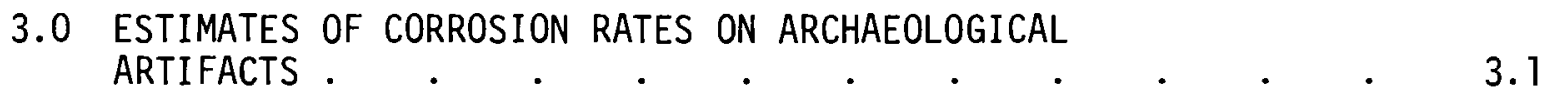

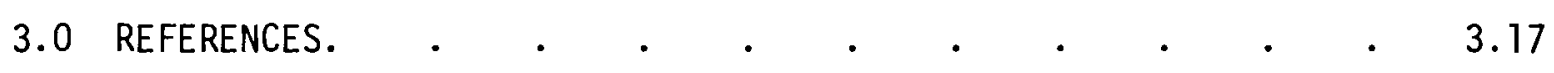

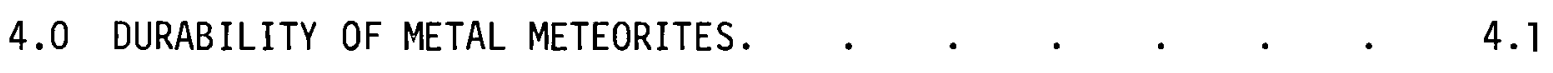




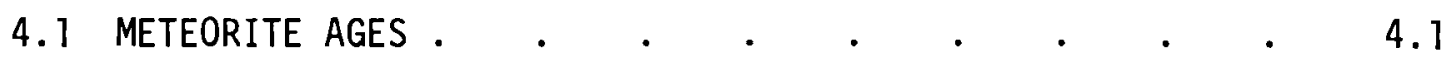

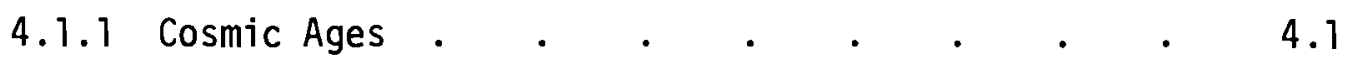

4.1 .2 Terrestrial Ages . . . . . . . . . . 4.3

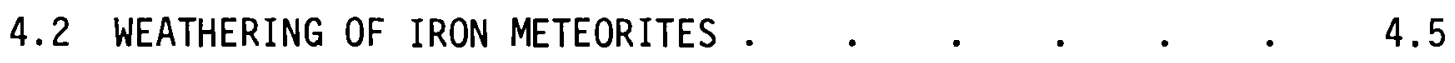

4.2.1 Features Which Index Degree of Weathering . $\quad 4.5$

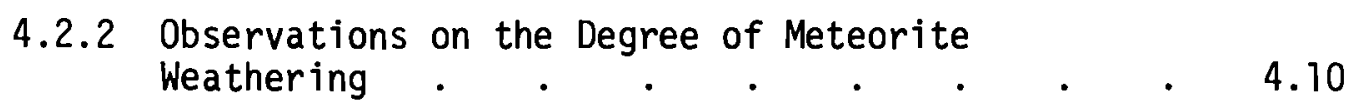

4.2.3 Stages of Meteorite Weathering . . . . 4.10

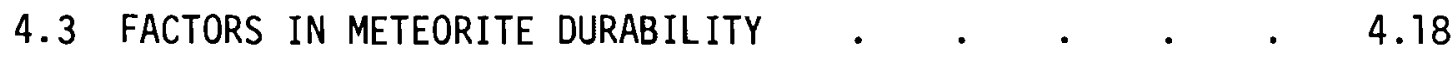

4.3.1 Effect of Fusion Crusts. . . . . . . 4.18

4.3.2 Effect of Burial or Partial Burial in Soil . . 4.20

4.3.3 Effect of Contaminants . . . . . . 4.22

4.3.4 Effect of Metallurgical Factors . . . . 4.22

4.3.5 Environmental Factors . . . . . . . 4.23

4.3.6 Effect of Nickel Content . . . . . . 4.24

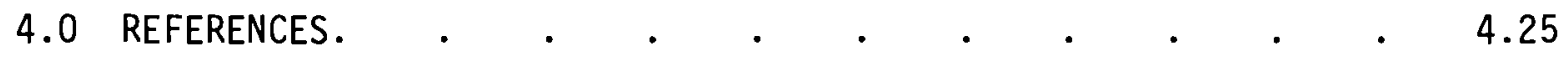

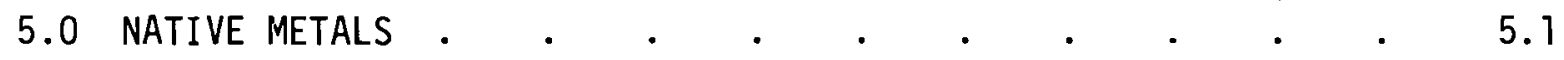

5.1 NATIVE GOLD, SILVER, PLATINUM, AND PALLAdIUM . . . 5.1

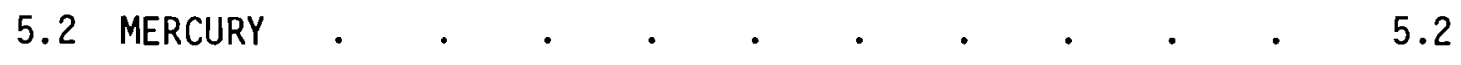

5.3 NATIVE IRON AND IRON-NICKEL ALLOYS • • • • • $\quad 5.2$

5.4 ARSENIC, ANTIMONY, AND BISMUTH..$\quad$. $\quad . \quad . \quad$. 5.3

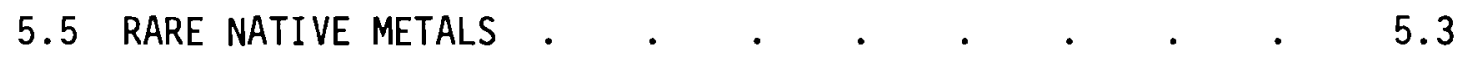

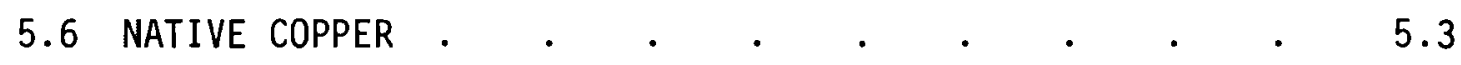

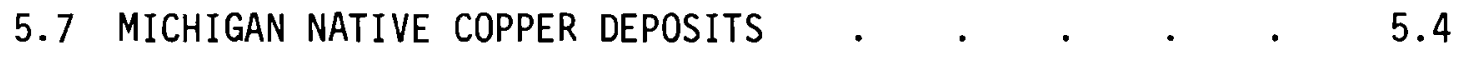

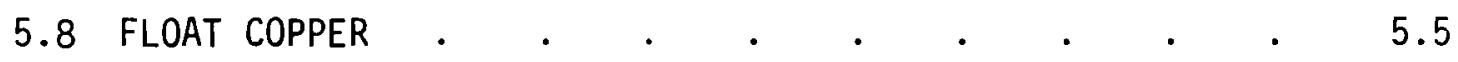


5.9 EXAMINATION OF WEATHERING ON FLOAT COPPER FROM THE

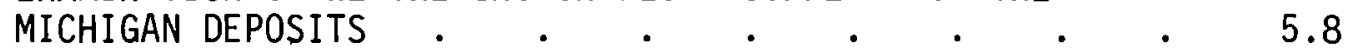

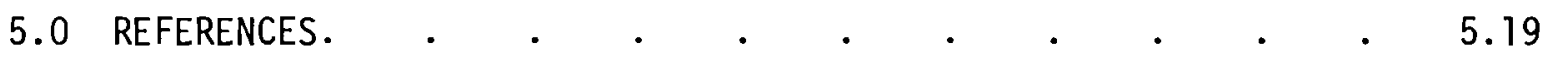

6.0 LONG-TERM METAL DURABILITY - DISCUSSION . . . . . . . 6.1

6.1 ANCIENT METAL UTILIZATION.

6.2 SUMMARY OF METAL DURABILITY $. \quad . \quad . \quad . \quad . \quad . \quad 6.1$

6.3 FACTORS IN METAL DURABILITY . . . . . . . 6.2

6.3.1 Metallurgical Processes. . . . . . . 6.2

6.3.2 Environments. . . . . . . . . . 6.2

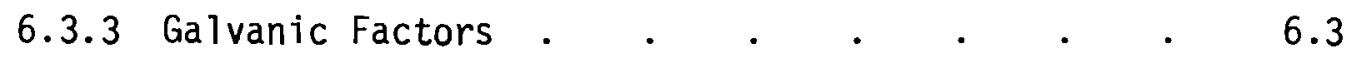

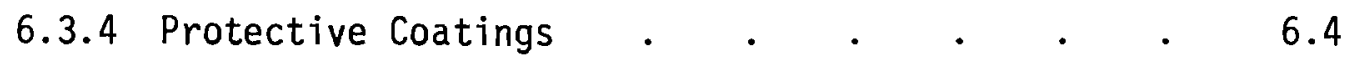

6.4 SOME PERSPECTIVES FROM THE STUDY . . . . . . . . 6.5

6.0 REFERENCES. . . . . . . . . . . . . . 6.9

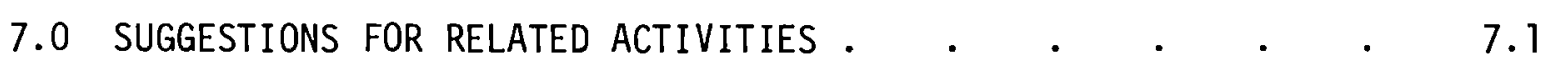

7.0 REFERENCES. . . . . . . . . . . . . . . . 7.3 


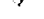

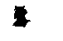


FIGURES

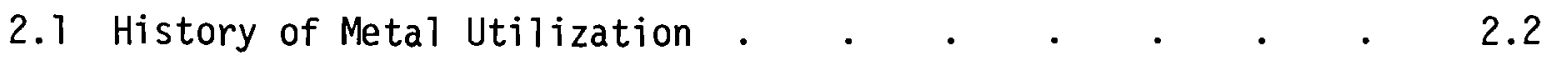

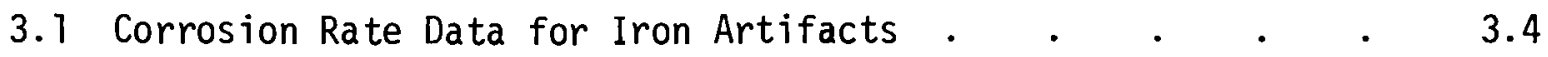

3.2 Corrosion Rate Data for Copper Alloy Artifacts $\quad$ • $\quad$ • $\quad 3.5$

4.1 Metal Meteorites With Known or Estimated Terrestrial

4.2 Metallographic Sections of N'Kandhla Meteorite . $\quad . \quad$. 4.7

4.3 Metallographic Sections of Rembang Meteorite ..$\quad$. $\quad 4.8$

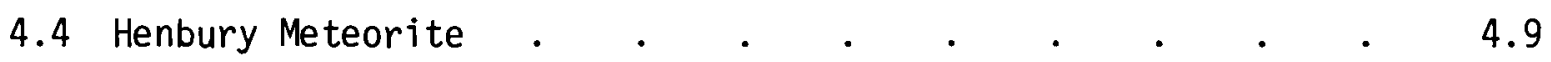

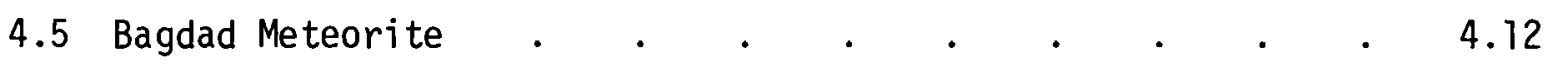

4.6 Metallographic Sections of Canyon Diablo Meteorite. $\quad$. $\quad 4.14$

4.7 Metallographic Sections of Henbury Meteorite . . . . 4.15

4.8 Metallographic Sections of Carbo Meteorite . . . . . 4.16

4.9 Ider Meteorite . $\quad . \quad$. $\quad . \quad$. $\quad . \quad$. $\quad$. 4.17

4.10 Slab of Mundrabilla (Octahedrite) on Display at the
Smithsonian Institution, Washington, DC . $. \quad . \quad . \quad 4.21$

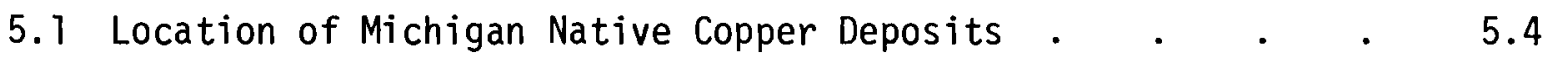

5.2a Artifacts Fashioned From Michigan Native Copper by Native

\begin{tabular}{l} 
5.2b Copper Breast-Plates From Hopewellian Period, 200 BC to \\
400 AD \\
\hline
\end{tabular}

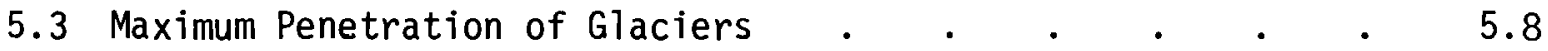

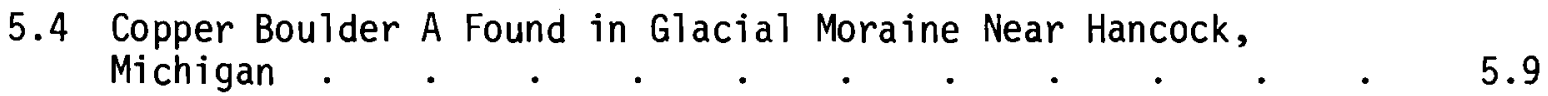

5.5 Section Cut From Copper Boulder, Figure 5.4 • $\quad$ • $\quad$ • $\quad 5.11$

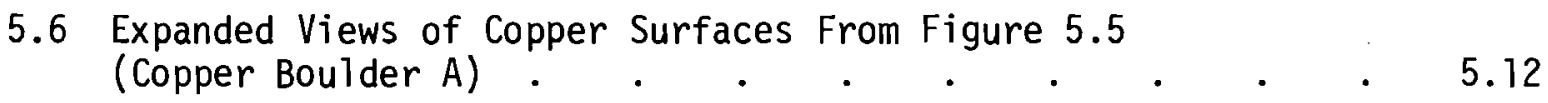


5.7 Cross-Section From Copper Boulder A, Figure 5.1, Area 2

5.8 Native Copper Boulder B Found Near Hancock, Michigan . . 5.15

5.9 Polished (a) and Etched (b) Section (A-B) of Copper

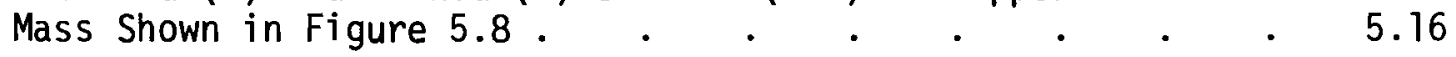

5.10 Duplex Oxide on Copper Boulder A . $\quad . \quad$. $\quad . \quad$. 5.17 


\section{$\underline{\text { TABLES }}$}

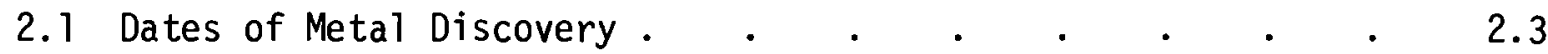

2.2 Properties and Probable Sources of Ancient Metals . . . 2.4

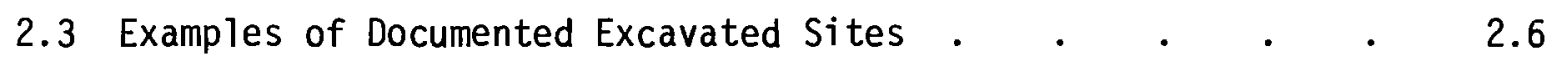

2.4 Examples of Archaeological Artifacts . . . . . . . 2.7

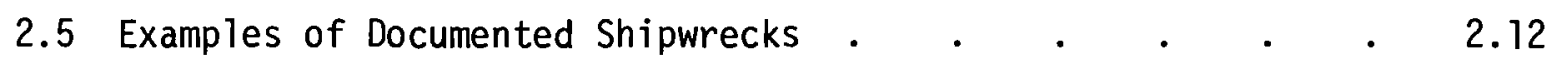

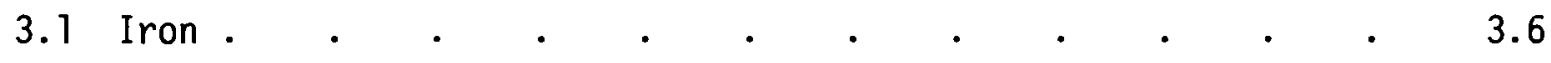

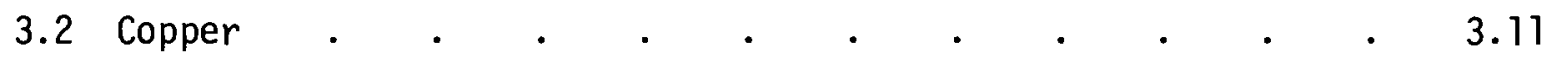

3.3 Lead . . . . . . . . . . . . . . . . . 3.15

3.4 Atmospheric Corrosion Rates From Modern Experience. . $\quad 3.16$

4.1 Metal Meteorites - Summary of Data . . . . . . . 4.2 


\subsection{INTRODUCTION}




\subsection{INTRODUCTION}

It is widely recognized that the safety of the high-level nuclear waste management system could be enhanced by containing the waste within a system of engineered barriers, such as canisters, overpacks and/or hole sleeves, that would last for a time period, in the range of 500 to 1,000 years. This engineered "package" would provide a barrier to radionuclide escape completely independent of the geologic medium containing the packaged waste during the period of highest waste toxicity and highest repository temperature. Estimation of the durability of materials in a repository environment over time periods of the order of $1,000 \mathrm{yr}$ is a difficult task. The present study was undertaken to assess the archaeological evidence for metal stability in a variety of environments, recognizing that the extrapolation of such data to anticipated waste repository conditions must be made with caution.

Several metals have survived for centuries and millenia in natural environments. The metals include archaeological artifacts, metal meteorites, and native metals. This report examines the range of metal durability for these materials and assesses factors which appear to have contributed to extended durability.

The present work was performed as part of the Engineered Barrier Development Task of the High Level Waste Immobilization Program. 
:

$+$ 


\subsection{METAL DURABILITY IN ARCHAEOLOGY}




\subsection{METAL DURABILITY IN ARCHAEOLOGY}

The so-called "seven metals of antiquity" are gold, silver, copper, lead, tin, iron, and mercury. (a) These metals and their alloys account for nearly all metal usage until the onset of modern metallurgy in the 1800s. We shall first briefly examine the history of metal usage, and define the state of knowledge regarding the durability of archaeological materials. Finally, corrosion rates will be estimated for archaeological materials (Section 3.0). The estimates will be compared to extrapolations of corrosion rates on similar modern metals.

\subsection{HISTORY OF METAL USAGE}

The history of metal use provides a useful background to an assessment of metal durability. Earliest dates of metal use are not well-established. In many cases, the environments over the life of a metal object can only be surmised. Even so, much can be learned regarding metal longevity from an assessment of ancient materials.

Figure 2.1 outlines a general overview of key developments in the Metal Age. The earliest evidence for human use of metals dates to $26000 \mathrm{BC}$ by archaeological dating. $(2,3)$ More recent carbon dating suggests somewhat earlier dates (6500-7000). (1) The early metal artwork and implements appear to have been derived from native metals, probably gold first, then copper. ${ }^{(1-4)}$

Table 2.1 indicates the earliest dates for human discovery of selected elements, based on a summary by Aitchison. (4) Discovery dates for some modern metals also are shown. However, dates for first separation of relatively pure metals were generally much later, for example, 1910 for titanium and 1914 for zirconium (hafnium-free, 1923).

Table 2.2 summarizes some properties and early sources of the principal ancient metals and their alloys.

(a) Tylecote ${ }^{(1)}$ points out that platinum also appeared in early metallurgy. Small amounts of metallic antimony also have been found. 


$\begin{array}{ccccc} & \text { NATIVE COPPER USE } & & \\ & & & \\ & & & \\ \text { IRON AGE } \\ \text { Ur } & \text { ASIA } & & & \\ \text { MILE VALLEY } & \text { MINOR } & \text { SUMER } & \text { CHINESE } & \text { GREEK \& ROMAN } \\ \text { MOHENJO-DARA } & \text { BRONZE } & \text { BRONZE } & \text { COINAGE }\end{array}$

$\stackrel{n}{n}$ MOHENJO-DARA

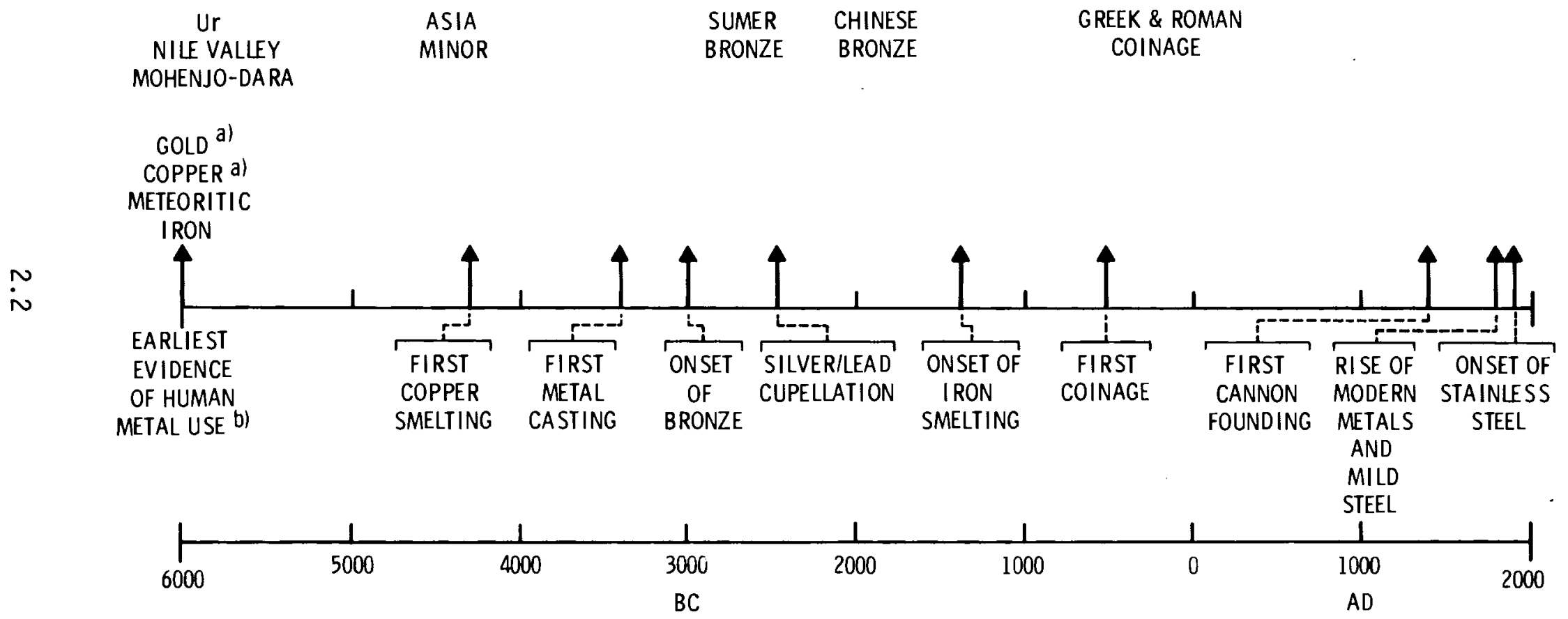

a) EARLY COPPER AND GOLD USE PROBABLY INVOLVED NATIVE METALS

b) TYLECOTE CITES ARTIFACTS DATED TO 6500-7000 BC, BASED ON CARBON DATING (1)

FIGURE 2.1. History of Metal Utilization, Neg. No. 7909499-10 
TABLE 2.1. Dates of Metal Discovery ${ }^{(4)}$

\begin{tabular}{|c|c|c|}
\hline Metal & Date ${ }^{(a)}$ & Remarks \\
\hline & $\underline{\mathrm{BC}}$ & \\
\hline Gold & Before 5000 & Probably native metal \\
\hline Copper (smelted) & $\sim 4200$ & Native copper used $26000-7000 \mathrm{BC}$ \\
\hline Silver & $\sim 4000$ & \\
\hline Lead & $\sim 3500$ & \\
\hline Tin & $\sim 2250$ & \\
\hline Iron (smelted) & $\sim 1500$ & Meteoritic Fe used earlier \\
\hline & $\underline{A D}$ & \\
\hline Mercury & $\sim 750$ & Some earlier use in antiquity \\
\hline Platinum & $\sim 1525$ & Some earlier use is indicated $(1)$ \\
\hline Zinc & $\sim 1721$ & Appeared in brasses before $600 \mathrm{BC}$ \\
\hline Nickel & $\sim 1751$ & Several ounces produced in 1804 \\
\hline Manganese & 21774 & \\
\hline Zirconium & 21789 & $\begin{array}{l}\text { First production of pure (except Hf) } \\
\text { metal was } 1912\end{array}$ \\
\hline Titanium & 21789 & First production of pure metal was 1910 \\
\hline Chromium & 21797 & \\
\hline Aluminum & ح1825 & First commercial production 1887 \\
\hline
\end{tabular}

(a) The dates suggest the maximum time span over which weathering behavior may be evaluated for a specific metal. For the modern metals, production dates are more relevant than discovery dates. 
TABLE 2.2. Properties and Probable Sources of Ancient Metals

\begin{tabular}{|c|c|c|c|}
\hline Metal & $\begin{array}{c}\text { Typical } \\
\text { Compositions } \\
\text { wt\% } \\
\end{array}$ & $\begin{array}{l}\text { Melting } \\
\text { Point } \\
{ }^{\circ} \mathrm{C} \\
\end{array}$ & $\begin{array}{c}\text { Probable Early } \\
\text { Sources }\end{array}$ \\
\hline Gold & $98-99 \mathrm{Au}$ & 1,064 & Native metal \\
\hline Silver & & 960 & $\begin{array}{l}\text { Native metal, silver chlo- } \\
\text { ride ores, argentiferous } \\
\text { lead ores }\end{array}$ \\
\hline Electrum & $\begin{array}{r}70-85 \mathrm{Au} \\
10-20 \mathrm{Ag} \\
0-15 \mathrm{Cu}\end{array}$ & -- & Natural gold/silver ores \\
\hline Copper & Often $>99 \% \mathrm{Cu}$ & 1,083 & $\begin{array}{l}\text { Native metal, malachite, } \\
\text { azurite }\end{array}$ \\
\hline Bronze & $\begin{array}{rl}75-98 & \mathrm{Cu} \\
2-15 \mathrm{Sn} \\
0-10 \mathrm{~Pb}\end{array}$ & $\begin{array}{l}1,000 \\
(95 \mathrm{Cu}, 5 \mathrm{Sn})\end{array}$ & $\begin{array}{l}\text { Smel ting natural or blended } \\
\text { copper and tin ores or } \\
\text { metals }\end{array}$ \\
\hline Brass & $\begin{array}{l}70 \mathrm{Cu} \\
30 \mathrm{Zn}\end{array}$ & $\stackrel{930}{(65 \mathrm{Cu}, 35 \mathrm{Zn})}$ & $\begin{array}{l}\text { Smelting blended or natural } \\
\text { copper and zinc ores }\end{array}$ \\
\hline Lead & sometimes $>99 \% \mathrm{~Pb}$ & 327 & Galena (lead sulfide) \\
\hline Tin & & 232 & Cassiterite (tin oxide) \\
\hline Pewter & $\begin{array}{l}75-80 \mathrm{Sn} \\
20-25 \mathrm{Cu}, \mathrm{Pb}, \mathrm{Sb}\end{array}$ & -- & \\
\hline Iron & & 1,536 & $\begin{array}{l}\text { Metal meteorites; later } \\
\text { smelting of iron ores }\end{array}$ \\
\hline Zinc & & 419 & Calamine (zinc carbonate) \\
\hline Mercury & & -38.9 & $\begin{array}{l}\text { Cinnabar (mercury sulfide); } \\
\text { possibly some native metal }\end{array}$ \\
\hline
\end{tabular}


The individual metal objects found by archaeologists probably number in the hundreds of thousands. The objects have come from a wide variety of geographic locations.

The metals have been exposed to a range of environments:

- soils of various compositons

- caves and tombs, often dry, but with a variety of moisture levels

- ancient buildings, e.g., temples and castles

- submerged shipwrecks

There are thousands of statues and other historical metal objects that have been exposed for centuries at indoor and outdoor locations throughout the world.

Table 2.3 indicates examples of archaeological sites that have been excavated and references where photographs of archaeological artifacts are available. Table 2.4 indicates examples of specific artifacts, including some of the oldest documented objects for several ancient metals.

\subsection{DURABILITY OF ARCHAEOLOGICAL METALS FROM LAND-BASED SITES}

Only a small fraction of the multitude of archaeological metal objects have been examined specifically for corrosion. Results of specific corrosion analyses will be summarized in Section 3.1. In some cases, the archaeologist has commented on the metallurgical state of a given object, providing a basis for evaluating the degree of corrosion. For example, Reference 8 provides photographs of metal artifacts in-situ in the tomb thought to belong to Philip of Macedon. Gold and silver appeared to be in excellent condition; bronze had a blue-green patina, with metal readily evident beneath on one object. Iron appeared to be substantially rusted, though the forms of iron artifacts were readily apparent. Often, photographs are published, providing a basis to judge the degree of preservation. That judgment must be employed with some caution because the appearance may be misleading; also, selected metal objects have been subject to restorative procedures which reduce or remove corrosion products. If specific artifacts appear to provide key information, inquiries to the curator are in order to characterize the condition, the probable environments and the degree of restoration. 
TABLE 2.3. Examples of Documented Excavated Sites

\begin{tabular}{|c|c|c|c|c|c|}
\hline Ref. & $\begin{array}{c}\text { Archaeological } \\
\text { Name }\end{array}$ & $\begin{array}{c}\text { Geographical } \\
\text { Location }\end{array}$ & $\begin{array}{l}\text { Approximate } \\
\text { Date of Use }\end{array}$ & $\begin{array}{c}\text { Excavation } \\
\text { Date } \\
\end{array}$ & Artifacts \\
\hline (5) & $\begin{array}{l}\text { Minoan tombs and } \\
\text { cities }\end{array}$ & Greece & $1400-2600 B C$ & $1876-1962$ & $\begin{array}{l}\text { Gold jewelry, masks, vessels; } \\
\text { copper mirror, ingots; bronze } \\
\text { statue, axes, armor }\end{array}$ \\
\hline (6) & $\begin{array}{l}\text { King Tutankhamen } \\
\text { tomb }\end{array}$ & $\begin{array}{l}\text { Egypt (Thebes) } \\
\text { Valley of the } \\
\text { Kings }\end{array}$ & $1300 \mathrm{BC}$ & 1922 & $\begin{array}{l}\text { Gold mask, dagger, armaments, } \\
\text { shrine, etc.; electrum boom- } \\
\text { erangs; silver trumpets, } \\
\text { inlays, etc.; bronze hinges, } \\
\text { nails, ornaments; iron dag- } \\
\text { gers, small tools }\end{array}$ \\
\hline (7) & Midianite temple & Timna, Israel & $1200-1300 \mathrm{BC}$ & 1969 & Copper serpent \\
\hline (8) & $\begin{array}{l}\text { Philip II of } \\
\text { Macedon tomb }\end{array}$ & $\begin{array}{l}\text { Aegae, Northern } \\
\text { Greece }\end{array}$ & $\sim 330 \mathrm{BC}$ & & $\begin{array}{l}\text { Gold casket, jewelry, quiver; } \\
\text { silver diadem, vessels; } \\
\text { bronze vessels and armor } \\
\text { (metallic); iron helmet, } \\
\text { stand (rusted) }\end{array}$ \\
\hline (9) & $\begin{array}{l}\text { Emperor } \mathrm{Ch}^{\prime} \text { in } \\
\text { Shih Huang } \mathrm{Ti} \\
\text { tomb }\end{array}$ & Mainland China & $\sim 210 \mathrm{BC}$ & 1974 & $\begin{array}{l}6,000 \text { terra-cotta soldiers; } \\
\text { bronze swords and spearheads; } \\
\text { iron farm tools; gold objects; } \\
\text { brass harness fittings }\end{array}$ \\
\hline
\end{tabular}




\section{TABLE 2.4. Examples of Archaeological Artifacts}

\begin{tabular}{|c|c|c|c|c|}
\hline Ref. & Artifact $^{(a)}$ & Location & Date & Remarks \\
\hline & & & $\underline{\mathrm{BC}}$ & \\
\hline (1) & Copper beads & $\begin{array}{l}\text { Catal Huyuk } \\
\text { (Turkey) }\end{array}$ & $7000-6500$ & \\
\hline (1) & Copper beads & $\begin{array}{l}\text { Al i Kosh } \\
\text { (Turkey) }\end{array}$ & $7000-5800$ & Native-oxidized \\
\hline (1) & Copper pin & Sialk (Iran) & 4500 & $\begin{array}{l}\text { Worked; relatively } \\
\text { good condition }\end{array}$ \\
\hline (1) & $\begin{array}{l}\text { Copper awls, needles, } \\
\text { knives }\end{array}$ & $\begin{array}{l}\text { Anau I } \\
\text { (Iran) }\end{array}$ & $4500-5500$ & \\
\hline (2) & Copper tools & Danube Basin & 24500 & \\
\hline (1) & Copper awls, pins & $\begin{array}{l}\text { Badrian } \\
\text { (Egypt) }\end{array}$ & $4000-5000$ & \\
\hline (1) & Sumer bronze objects & Brak (Syria) & 3000 & \\
\hline (2) & oldest gold jewelry & $\begin{array}{l}\text { Varna } \\
\text { (Bulgaria) }\end{array}$ & 3500 & \\
\hline (3) & Smel ted copper & $\begin{array}{l}\text { Near Ur } \\
\text { (Iraq) }\end{array}$ & 3400 & \\
\hline (3) & Copper tools & Egypt & 2900 & $\begin{array}{l}\text { First copper } \\
\text { found in tombs }\end{array}$ \\
\hline (2) & Gold helmet & $\begin{array}{l}\text { Mes-Kalam- } \\
\text { Dug tomb } \\
\text { (Iraq) }\end{array}$ & pre 3000 & \\
\hline (2) & Lead figure & $\begin{array}{l}\text { Osiris } \\
\text { (Egypt) }\end{array}$ & $\sim 3000$ & \\
\hline (2) & Copper ewers & Egypt & $\sim 2800$ & $\begin{array}{l}\text { Appear well- } \\
\text { preserved }\end{array}$ \\
\hline \multirow[t]{2}{*}{ (3) } & $\begin{array}{l}\text { Silver vase on } \mathrm{Cu} \\
\text { stand }\end{array}$ & Laqash, Iraq & $\sim 2800$ & \\
\hline & Tin bracelet & $\begin{array}{l}\text { Thermi } \\
\text { (Lesbos) }\end{array}$ & $\imath 2700-2550$ & $\begin{array}{l}\text { 0ldest tin } \\
\text { artifact }\end{array}$ \\
\hline (2) & $\begin{array}{l}\text { Iron dagger, brace- } \\
\text { let, head rest, } \\
\text { miniature tools }\end{array}$ & $\begin{array}{l}\text { King } \\
\text { Tutankhamen }\end{array}$ & $\sim 1350$ & $\begin{array}{l}\text { May be oldest man- } \\
\text { made iron articles }\end{array}$ \\
\hline
\end{tabular}

$\underline{A D}$

(4) Iron Pillar of Delhi India $400 \quad$ Still in good

(4) Cast iron water pipes Versailles, 1665 Still in use v1960 France

(a) Gold and silver are not treated here in detail; the oldest known gold artifact dates from the end of the 5 th millennium BC; however, gold perhaps was not buried in early tombs and graves. 
Some generalizations regarding the durability of specific ancient metals are given below.

\subsubsection{Gold}

Gold is undoubtedly the most durable of the ancient materials. However, no gold artifacts dating prior to $\mathbf{4 5 0 0 - 5 0 0 0 ~ B C}$ have been found, suggesting that early burial practice did not include gold. Gold has survived in a variety of soils, moist and dry tombs, and shipwrecks, generally with no more than a mild tarnish or some encrustations. Gold alloys with silver, platinum, copper, etc., also have been durable, although parting (metal separation) has occurred. Earliest coinage appears to date to $\sim 700 \mathrm{BC}$ in Lydia (Agean), involving the gold-silver alloy electrum.

\subsubsection{Copper}

Copper was among the first metals used for weapons and implements, beginning with high purity native coppers. Smelting (Figure 2.1) also produced relatively pure copper. Some slags may date prior to $5000 \mathrm{BC}$; by $4000 \mathrm{BC}$, smelting was practiced at several Asian sites. Citing from specific comments regarding early copper artifacts: (1)

- A small copper bead from Ali Kosh, Iran, dated to the 7 th millenium BC was fully oxidized. It was made of rolled up copper sheet about $0.4 \mathrm{~mm}$ thick. There is little doubt that it was native copper.

- A copper pin from Sialk was in much better condition, dating from the 5 th millenium $B C$. It was a heavily-worked native copper.

- At one archaeological site, brass objects appeared to survive better than their bronze contemporaries. (10) Arsenical copper (a) from Troy I ( 23000 $B C$ ) was found to be badly corroded. Copper coins in a wrecked Dutch ship were corroded but still had recognizable dates after 360 years in sea water. (11)

Numerous photographs and descriptions suggest that copper has survived quite well in numerous environments. $(1-7)$

(a) Arsenical coppers contain arsenic in the range of 1.9 to $12.0 \mathrm{wt} \%$. 


\subsubsection{Bronze}

Early bronzes probably resulted from simultaneous smelting of copper and tin ores. Some bronzes have shown excellent durability. For example, the bronze objects in the tomb of King Tutankhamen appeared to be in excellent condition after $\sim 3,300$ years. ${ }^{(6)}$ A recent remarkable archaeological find in China ${ }^{(9)}$ involved 6,000 full-sized terra-cotta figures of soldiers with actual weapons, spears, swords, etc., many of them in bronze (copper-tin alloy, with small amounts of nickel, magnesium, cobalt, and traces of ten other elements). A brief description indicates that the bronze was "treated with a preservative that prevented corrosion for 22 centuries." The nature of the "preservative" remains to be defined.

Our own analysis of a bronze fibula (pin) from the Gordian tomb (Turkey, 700-800 BC) revealed intergranular corrosion and numerous, oriented stringers, though the piece was still largely metallic. Substantial chloride contamination was present on the fibula. A type of attack called "bronze disease" has been identified, ${ }^{(12)}$ caused by a combination of a metal/chloride reaction product and moisture, resulting in rapid deterioration of bronze metal, particularly when moved from a dry to a moist environment.

We have inspected Egyptian bronze axe heads in the British Museum, dated from $\sim 2000 \mathrm{BC}$ which appeared to be sound, with no more than a heavy tarnish.

Arsenical copper (1-12\% As) is sometimes confused with bronze (1-15\% Sn) because the appearances often are similar. (1) Thus, bronze may have been blamed for some poor corrosion resistance occurring on arsenical copper. On the other hand, some arsenic is beneficial to prevent destannification (tin loss) from bronzes.

\subsubsection{Lead}

Meta1lic lead dated to $3000-3500 \mathrm{BC}$ has been found, undoubtedly smelted because lead does not occur in the native form.

The corrosion resistance of lead in aqueous environments was recognized, particularly by the Romans, who built lead-lined water systems. Lead also was used as a sheathing material for ships (Section 2.3), but the mechanical properties were not attractive for most weapons and implements. 
Lead oxides and carbonates appear to be protective. However, museum curators have discovered that lead objects are degraded by organic acids (e.g., acetic acid). Volatile products from oak show cases and cardboard have been corrosive to lead.

\section{2 .5 Iron}

The earliest iron artifacts appear to come from metal meteorites. (1) Nickel contents for the meteorites commonly fall in the range of 5 to $11 \mathrm{wt} \%$ (see Section 4.1). Nickel in iron ores never seems to exceed 1 wt\%. Tylecote ${ }^{(1)}$ remarks that meteoritic iron has been more durable than smelted iron, which he attributes to the higher nickel content.

The iron articles in the tomb of King Tutankhamen appear to be among the oldest examples of iron archaeological artifacts.

\subsubsection{Tin}

The oldest tin artifact is a bracelet from Lesbos, dated to 2550-2700 $B C$. (3) However, few other metallic tin objects have been found predating the Roman period $(500 \mathrm{BC})$. A photograph of the bracelet suggests good conformity, but the metallurgical condition is not indicated.

The generally good corrosion resistance of tin was recognized by the ancient metallurgists and "tinning" or coating with tin from a molten bath appears to have been used for corrosion prevention.

\subsubsection{Silver}

Silver, while less corrosion-resistant than gold, has an impressive history of durability. Silver objects in the King Tutankhamen tomb (1300 BC) were well-preserved. Some early, badly-degraded silver objects found near Ur (from $\sim 3000 \mathrm{BC}$ ) were apparently attacked by chlorides.

\subsubsection{Pewter}

Pewter is a tin-base alloy (Table 2.2). Some Roman pewter (1500-2000 years old) is in relatively good condition. 


\subsection{DURABILITY OF METALS IN SEA WATER}

We frequently observe that metals in contact with water degrade, particularly when the water is saline. Therefore, it is somewhat surprising to find that some metals have survived for very long times in salt water. Approximately twenty shipwrecks dating from 2500 to $80 \mathrm{BC}$ have been located and partially excavated. (13) Another dozen investigated wrecks date to the period 40 to 300 AD. The Medieval Period (500 to 1400 AD) accounts for more than 2 dozen characterized wrecks. Several dozen wrecks have been investigated, covering the period 1500 to $1700 \mathrm{AD}$. Table 2.5 gives examples of documented shipwreck excavations, where pictures of metal objects are published, including some remarkable examples of durability. Gold has the best history of durability in sea water, but other metals also have survived over several centuries.

Tylecote ${ }^{(23)}$ has summarized metal durability in shipwrecks. He documents cases of sunken ships dating from 1588 AD to $21200 \mathrm{BC}$.

In brief, he provides the following insights to metal corrosion in seawater:

- Copper ingots from a 1200 BC shipwreck off Southern Turkey were in poor condition; the ingots had a relatively high iron content; similar landbased ingots have survived in good condition, but have had lower iron contents.

- Bronze artifacts from another $1200 \mathrm{BC}$ wreck off Dover, England were in "extremely good condition." The relatively pure (nonleaded) bronze was suggested to be a factor in the durability.

- A wreck from the Punic period ( $400 \mathrm{BC}$ ) off the Sicilian coast (Marsala) included wood, lead sheet, bronze, copper, and iron nails, with possible interactions among the materials. Nails remaining in the wood showed no intergranular attack and very little general attack. They may have been protected by tannins. Iron objects formed a porous limy concretion; the iron eventually corroded out, leaving an empty cavity.

- A copper nail from a Punic wreck (Kyrenia) was examined. A lime concretion had formed on the exterior of the nail. There was no evidence of intergranular attack. Thinning of the copper by corrosion appeared to be $\sim 25 \%$. Sulfate-reducing bacteria were probably responsible for converting the corrosion products to sulfides of lead and copper. 
TABLE 2.5. Examples of Documented Shipwrecks

\begin{tabular}{|c|c|c|c|c|c|}
\hline Ref. & Ship Name/Source & Wreck Location & $\begin{array}{c}\text { Approximate } \\
\text { Date of Wreck }\end{array}$ & $\begin{array}{c}\text { Date } \\
\text { Excavated }\end{array}$ & Artifacts \\
\hline (14) & $\begin{array}{l}\text { 0ldest known } \\
\text { Bronze-Age ship }\end{array}$ & $\begin{array}{l}\text { Cape Gelidonya, } \\
\text { Turkey }\end{array}$ & $\sim 1200 \mathrm{BC}$ & 1960 & $\begin{array}{l}\text { Copper ingots; bronze weap- } \\
\text { ons, tools, ingots; (tin } \\
\text { fully oxidized, but natural } \\
\text { casserite not ruled out) }\end{array}$ \\
\hline
\end{tabular}

Notes on condition: Some copper in excellent condition next to highly-corroded bronze; at some locations, copper and bronze were corroded; tin was white powdery oxide.

(15) Byzantine ship Yassi Island,
Turkey

$\begin{array}{lll}\text { (17) } \begin{array}{ll}\text { Argosy (Greek } \\ \text { Wineship) }\end{array} & \begin{array}{l}\text { Near Marseille, } \\ \text { France }\end{array} & \text { w230 BC }\end{array}$
Near Marseille France

Bronze weight (lead-filled), scale; ceramic vessels; gold coins; iron anchors (corroded); copper cauldron; silver, inlay on weights; glass pendant

Lead sheath and rings; copper tacks and nails; ceramic wine jars; iron chisel; five bronze coins $(a)$

Note: Burial in ocean bottom mud appeared to be a factor in preservation of materials. Lead anchor was exposed. Sealed wine jars had not absorbed salt water.

$$
\begin{aligned}
& \text { Off Serce Limini } 21025 \text { AD } \\
& \text { (Turkey) }
\end{aligned}
$$

1977

Bronze weights; lead sinkers; iron anchors; bronze buckets; copper coins; glassware and cullet 
TABLE 2.5. (contd)

\begin{tabular}{|c|c|c|c|c|c|}
\hline Ref. & Ship Name/Source & Wreck Location & $\begin{array}{l}\text { Approximate } \\
\text { Date of Wreck }\end{array}$ & $\begin{array}{c}\text { Date } \\
\text { Excavated }\end{array}$ & Artifacts \\
\hline (19) & Chinese Vessel & $\begin{array}{l}\text { Off Southwest } \\
\text { Coast of Korea }\end{array}$ & 21300 AD & 1976 & $\begin{array}{l}\text { Bronze utensils, weights, } \\
\text { disk; silver ingots; iron } \\
\text { ingots; metal coins; ceramic } \\
\text { ware }\end{array}$ \\
\hline$(20)$ & $\begin{array}{l}\text { Girona (Spanish } \\
\text { Armada ship) }\end{array}$ & $\begin{array}{l}\text { Northern } \\
\text { Ireland }\end{array}$ & $\begin{array}{l}1588 \text { AD } \\
\text { (Oct.) }\end{array}$ & $\begin{array}{l}1967 \\
\text { (June) }\end{array}$ & $\begin{array}{l}\text { Gold, silver coins, artifacts } \\
\text { copper coins and artifacts; } \\
\text { bronze cannon; cast iron can- } \\
\text { non; brass cannon and arti- } \\
\text { facts; lead ingots and sheet }\end{array}$ \\
\hline$(11)$ & $\begin{array}{l}\text { Witte Leeuw } \\
\text { Dutch }\end{array}$ & $\begin{array}{l}\text { Off St. Helena } \\
\text { (South Atlantic) }\end{array}$ & $1613 \mathrm{AD}$ & 1975 & $\begin{array}{l}\text { Silver whistle and chain; } \\
\text { brass lamp; cast iron and } \\
\text { bronze cannon with iron } \\
\text { inscription; lead ballast; } \\
\text { ceramic dishes; iron shot }\end{array}$ \\
\hline (21) & Vasa, Swedish & $\begin{array}{l}\text { Stockholm } \\
\text { Harbor }\end{array}$ & 1628 AD & 1954 & $\begin{array}{l}\text { Iron cannon; wrought and } \\
\text { cast objects }\end{array}$ \\
\hline
\end{tabular}

Note: Wrought iron objects in advanced stages of corrosion; cast iron objects were much more corrosion resistant

$\begin{array}{lll}\text { (22) Slot ter Hooge } & \text { Porto Santa, } \\ \text { Dutch trading } & \text { Madeira Islands } & \text { (Nov.) } \\ \text { ship } & \text { (Nov.) }\end{array}$

1975
Silver bars, coins; ${ }^{(b)}$ brass cannon; lead ingots; iron ingots and cannon; copper sheets, wire; cast iron anchor (rusted); gold artifacts

(a) Corroded but readable.

(b) Coins embedded in concretions were usually in good condition; coins lying loose on the sand generally were corroded; those lodged vertically in crevices were honed to sharp edges on the rocks. 
- Galvanic factors are particularly important in seawater. Iron nails were a failure for attaching copper sheets to ships due to anodic corrosion. Where multiple metals are found in a wreck, the prospect of galvanic corrosion must be considered in assessing metal durability.

- Brasses were found in later wrecks (1600-1700 AD). Increasing copper content appears to increase their corrosion resistance and As, Sb, or $P$ suppress dezincification.

- Lead and bronze seem to have similar durabilities in seawater, though the experience with bronze in seawater goes back further. Dating to the Roman period, lead ingots, anchors, sail rings, etc. appear to have had excellent resistance to seawater.

- Some pure ( $299.9 \%)$ tin ingots from the Roman period have survived quite well, but generally the resistance of tin to seawater has not been impressive. Pewter has not appeared in the Roman period wrecks. Pewter from post-medieval wrecks (1588-1711) were found in relatively good condition, including residual knife marks on pewter plates. Tylecote suggests that the more impure pewters may have higher resistance to seawater.

Tylecote dismisses iron for extended use in seawater. Iron cannon, cannon bal1s, and other iron artifacts have survived in some wrecks. $(21,23)$ However, those which survived best were buried in mud or silt, promoting anaerobic conditions. In fact, cases are documented where iron cannon survived relatively well for centuries in a shipwreck, but underwent accelerated corrosion when removed to the atmosphere. (21)

Other documentation regarding shipwrecks (e.g., Refs. in Table 2.5) tend to substantiate Tylecote's conclusions regarding multi-century durability of lead $(16-18,20-22)$ and bronze $(15-22)$ in seawater. However, the rather cursory description of metal condition in most of the references is less definitive than Tylecote's study, which includes some first-hand investigation of corrosion on metals from shipwrecks.

\subsection{DURABILITY OF NON-METALS}

While non-metals are not within the scope of this study, much information regarding the durability of glasses and ceramic materials is documented. For 
example, Ref. 18 describes glassware and ceramics which were exposed to seawater for almost 1,000 years. Some glassware had degraded while other types appeared essentially intact. Comparison of the glass analyses may provide insights to formulations which have maximum stability to seawater.

Ceramic dinnerware, vases, jars, etc., also have survived essentially intact for many centuries in shipwrecks. (15-19)

Similar information is documented for non-metals found in land-based archaeological sites. (24)

A recent study summarizes the durability of ancient glasses and ceramics. 
$-$ 


\subsection{REFERENCES $(a)$}

1. R. F. Tylecote. A History of Metallurgy. The Metal Society, London, 1976.

2. J. G. Parr. Man, Metals and Modern Magic. American Society for Metals and Iowa State College Press, Armes, IA, 1958.

3. L. Aitchison. A History of Metals. Vol. I, Interscience Publishers, New York, NY, 1960.

4. Ibid., Vol. II.

5a. J. Judge. "Greece's Brilliant Bronze Age." Nat. Geog. 153:142-185, February 1978.

5b. R. Higgins. Minoan and Mycenean Art. London, 1967.

6. H. Carter. The Tomb of Tutankhamen. Excalibur Books, 1954.

7a. H. Arden. "In Search of Moses." Nat. Geog. 149:30, January 1976.

7b. B. Rothenberg. Timna: Valley of the Biblical Copper Mines. London, 1972.

8a. M. Andronicos. "Regal Treasures from a Macedonia Tomb." 154:55-77, July 1978.

8b. M. Andronikos. "The Royal Tomb of Philip II: An Unlooted Macedonian Grave at Vergina." Archaeology. 31, 1978, 33-41.

9a. A. Topping. "China's Incredible Find." Nat. Geog. 153:440-462, April 1978.

9b. R. E. Ruldolph. "The First Emperor's Underground Army." Archaeology. $28,1975,267-69$.

10. J. A. Smythe. "Roman Objects of Copper and Iron From the North of England." Proc. Univ. of Durham Phil. Soc. 9:n.6, pp. 382-405, 1938.

11. R. Stéinuit. "The Sunken Treasure of St. Helena." Nat. Geog. 154:562-76, October 1978.

12. Bronze Disease and Its Treatment. Published by Banghok National Museum, Department of Fine Arts, 1975.

13. K. Hudson and A. Nichols. Tragedy on the High Seas - A History of Shipwrecks. A\&W Publishers, New York, NY, 1979.

(a) References listed as (a) are in the more popular literature, and often include colored photographs. Parallel references listed as (b) tend to be more technical. 
14. P. Throckmorton. "01dest known Shipwreck Yields Bronze Age Cargo." Nat. Geog. 121:697, 1962.

15a. G. F. Bass. "Underwater Archaeology: Key to History's Warehouse." Nat. Geog. 124:138, 1963.

15b. G. F. Bass. "Underwater Excavation at Yassi Ada." Archaeologischen Anzeiger. 1962, 537-64.

16a. S. W. and M. L. Katzev. "Last Harbor for the 01dest Ship." Nat. Geog. $146: 618,1974$; also $137: 841,1970$.

16b. M. Katzev. "The Kyrenia Shipwreck." Expedition. 11, 1969, 55-59.

17. J. Cousteau. "Fish Men Discover a 2,000 Year 01d Greek Ship." Nat. Geog. CV:1-36, January 1954.

18. G. F. Bass. "The Shipwreck at Serce Liman, Turkey." Archaeology. 32, $1979,36-41$.

19. H. E. Kim and D. H. Keith. "The Yellow Sea Yields a Shipwreck Treasure Trove." Nat. Geog. 156, 1979, 231-243.

20. R. Stéinuit. "Priceless Relics of the Spanish Armada." Nat. Geog. $135: 747-777,1969$.

21. Corrosion and Metal Artifacts. NBS Special Publication 479, U.S. Department of Commerce, National Bureau of Standards, Washington, DC, July 1977, pp. 155-166.

22. R. Stéinuit. "The Treasure of Porto Santo." Nat. Geog. 148:261-275, 1975.

23. R. F. Tylecote. Durable Materials for Seawater: The Archaeological Evidence. British Nuclear Fuels Limited (BNFL) Report 314 (R), 1977.

24. A. Lucas. Ancient Egyptian Materials and Industries. London, 1962.

25. M. F. Kaplan. Ancient Materials Data as a Basis for Waste Form Integrity Projections. SP-1749-1, Analytical Sciences Corporation, Reading, MA, August 1979. 


\subsection{ESTIMATES OF CORROSION RATES ON ARCHAEOLOGICAL ARTIFACTS}




\subsection{ESTIMATES OF CORROSION RATES ON ARCHAEOLOGICAL ARTIFACTS}

The foregoing discussion of durability of archaeological artifacts was based largely on inferred rather than direct evidence of corrosion performance. In many cases, the corrosion has appeared to be minimal, but the archaeologist has not permitted direct corrosion measurements which would disturb the conformity and completeness of the artifact. This section deals with artifacts where corrosion was either quantified by metallurgical examination or by other quantitative or semi-quantitative techniques.

Corrosion failure can occur by general or localized mechanisms. The engineering/scientific community has a working knowledge of these corrosion modes for normal design lifetimes of twenty years or so, but very little knowledge of what to expect over the centuries required for long-term waste storage. One approach is to extrapolate short-term corrosion data to estimate long-term behavior. Another approach is to assess the corrosion of metal objects which have survived for centuries or millenia. In our view, it is highly desirable to check the extrapolation of short-term corrosion data against actual longterm data. In a preliminary assessment, we have estimated the corrosion rates for a number of archaeological artifacts and having compared the rates to extrapolated corrosion rates for corresponding modern materials.

There are problems inherent in determining corrosion rates on archaeological metals. Foremost is the inadequacy of most artifact descriptions in the archaeological literature. Frequently, the only basis for a corrosion assessment is a photograph or a brief description such as "lightly" or "severely" corroded. Only occasionally does one have an adequate description of the corrosion, including radiographs of the artifact, analyses of the corrosion products, or photomicrographs of metallurgical cross-sections showing the corrosion layer thickness. Even then there is uncertainty regarding the location of the original corroded surface. Furthermore, the artifact may have been cleaned and/or restored, and its age may be uncertain. Finally, some artifacts have both general surface corrosion and grain boundary corrosion (particularly tin bronzes), which makes it difficult to evaluate a composite corrosion rate. 
These factors compromise precise corrosion rate measurements. However, it is still possible and useful to estimate some corrosion rates, using methods described later.

Another factor influencing the usefulness of the estimates is that with few exceptions, the corrosion environment for the artifact was known to us onily in very general terms, such as "wet" or "dry". Therefore, it is difficult to directly compare long-term corrosion rates of artifacts of the same basic material (e.g., iron) in different environments. However, it may be possible to detect trends.

The corrosion rate estimates are shown in Figure 3.1 for iron base artifacts and in Figure 3.2 for copper base artifacts. These figures show estimated corrosion rates in inches and centimeters per one thousand years. The numbers associated with each estimate refer to Tables 3.1 and 3.2. The Tables provide information for the corrosion rates plotted in the figures, namely the reference to archaeological literature, minimum and maximum estimated corrosion rates, corrosion environment, information and appropriate remarks relating to the estimate, such as composition.

The corrosion estimates are from written descriptions, photographs, photomicrographs, drawings, radiographs, or various combinations of these. The minimum and maximum corrosion rates for each artifact represent best estimates, based on the available descriptions. All estimates assume uniform corrosion.

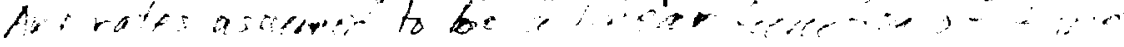

Corrosion rates of a few lead artifacts have also been estimated (Table 3.3). There are not enough estimates to justify definitive statements, but it does appear that the median corrosion rate for lead artifacts is similar to rate for iron- and copper-base artifacts.

It is only fair to acknowledge that many artifacts have corroded completely. However, in the nuclear waste context, we have particular interest in rates at the low end of the corrosion rate scale. What rates can be achieved under carefully engineered conditions?

It is informative to compare the estimated corrosion rates on artifacts with corrosion rates for corresponding modern metals. The atmospheric corrosion 
of copper, lead, and iron as quoted by Uhlig(31) are shown in Table 3.4. These values represent average corrosion rates over 8 to 20 years. Maximum and minimum values are listed from the composite data of urban-industrial, marine, and rural atmospheres. The minimum values generally correspond to the rural atmosphere data.

The modern atmospheric corrosion rates are near the midpoint of the corrosion rate estimates for all three materials. However the modern rates are several orders of magnitude higher than the estimated rates for the most durable artifacts we have surveyed. The most durable artifacts have been subject to exceptionally low corrosion rates.

This attempt to quantify archaeological corrosion rates is of very limited scope. We would welcome comments from archaeological specialists regarding the validity of the comparisons and regarding any other relevant data not included here.

Also, we would welcome comments from specialists on the corrosion of modern metals regarding the most appropriate basis for corrosion rate extrapolations which are relevant to the ancient metals. 


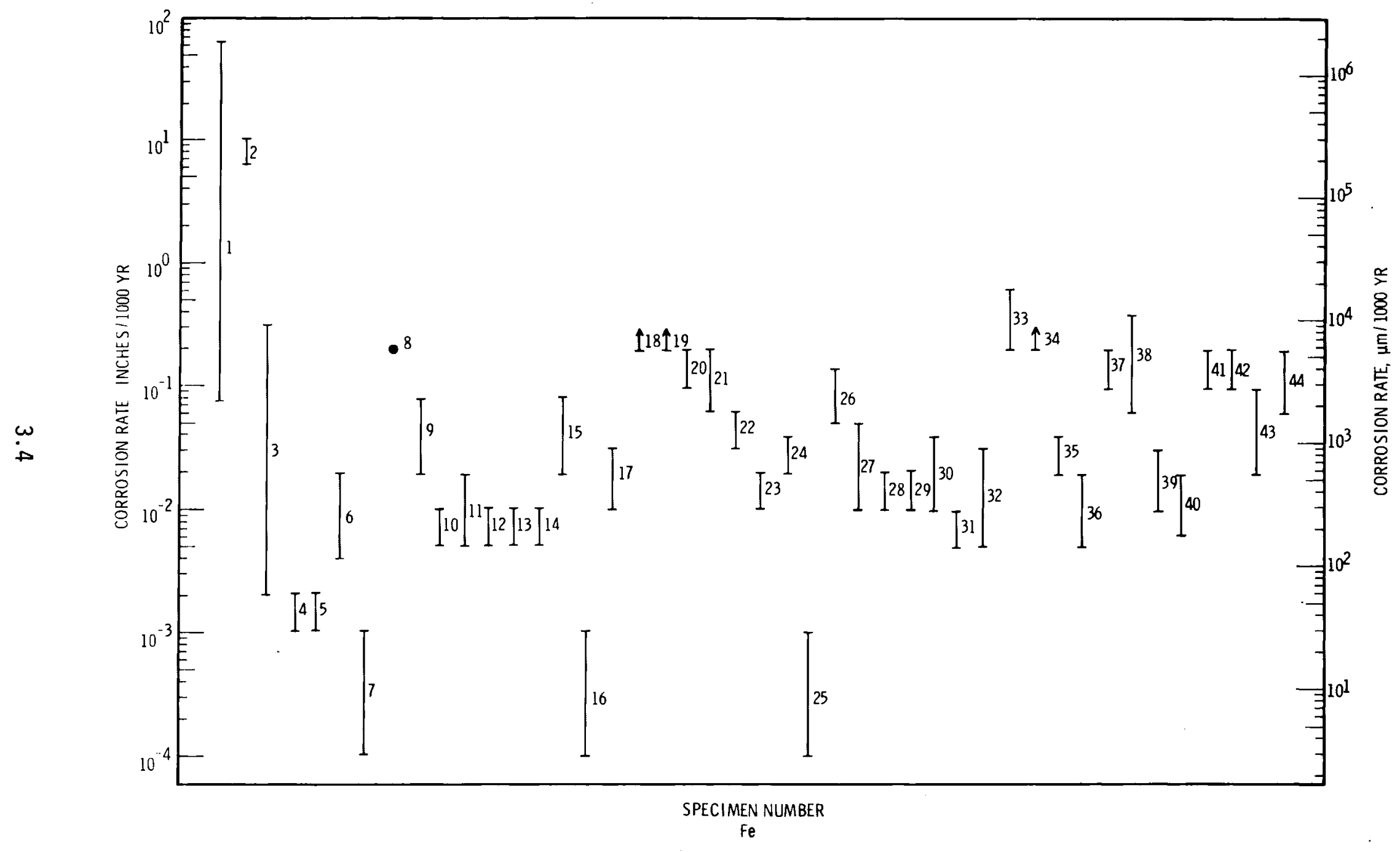

FIGURE 3.1. Corrosion Rate Data for Iron Artifacts 


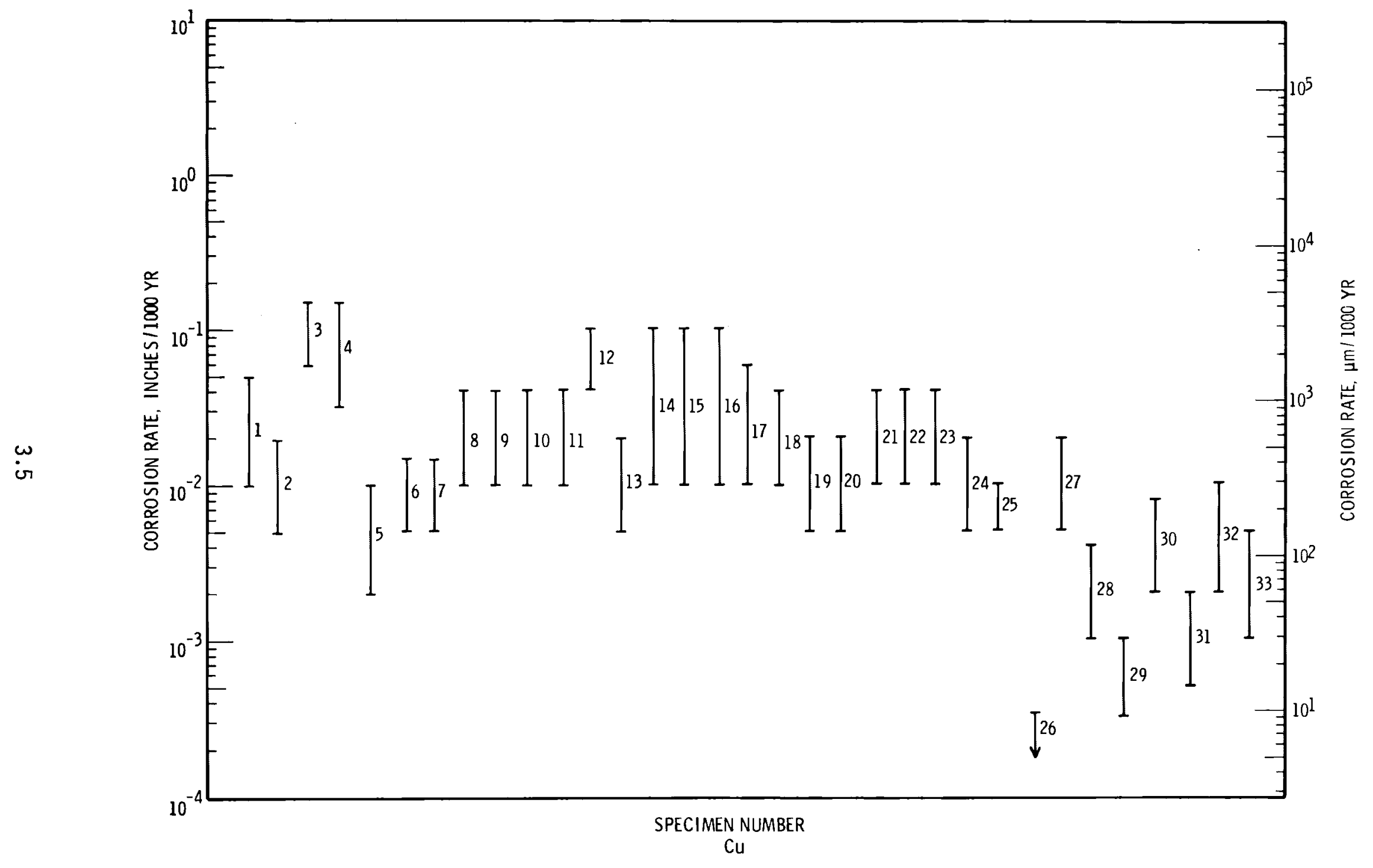

FIGURE 3.2. Corrosion Rate Data for Copper Alloy Artifacts 
TABLE 3.1. Iron

\begin{tabular}{|c|c|c|c|c|c|}
\hline & Artifact Reference \# & \multicolumn{2}{|c|}{$\begin{array}{l}\text { Corrosion Rate } \\
\text { Inches } / 1000 Y R^{(a)}\end{array}$} & Environment & \multirow[t]{2}{*}{ Remarks } \\
\hline & & Min. & Max. & & \\
\hline 1. & $\begin{array}{l}\text { Cast iron cannon balls } \\
{[6, \mathrm{pg} 155]}\end{array}$ & 0.08 & 17 & $\begin{array}{l}\text { sea water and mud, } \\
\text { waterlogged (below } \\
\text { sea level) }\end{array}$ & $\begin{array}{l}\text { Authors measurement and chemical } \\
\text { analyses. Worst corrosion on } \\
\text { balls directly exposed to sea, } \\
\text { least on balls covered by mud. }\end{array}$ \\
\hline 2. & $\begin{array}{l}\text { Cast iron cannon balls } \\
1, p g\end{array}$ & & $7-10$ & sea water & Measurement quoted. \\
\hline 3. & Iron nails $[6, p g 33]$ & 0.002 & 0.3 & $\begin{array}{l}\text { buried in ground } \\
\text { [England] }\end{array}$ & $\begin{array}{l}\text { Estimate from corrosion descrip- } \\
\text { tion and physical size of nails. }\end{array}$ \\
\hline 4. & Iron nail $[6, p g$ 33] & 0.001 & 0.003 & not given [England] & $\begin{array}{l}\text { Estimate from metallographic } \\
\text { cross-section. }\end{array}$ \\
\hline 5. & Iron nail $[6, \mathrm{pg} 39]$ & 0.001 & 0.003 & $\begin{array}{l}\text { not given } \\
\text { [United States] }\end{array}$ & $\begin{array}{l}\text { Same as above. pitted in some } \\
\text { areas with rest in pitted areas }\end{array}$ \\
\hline 6. & $\begin{array}{l}\text { Currency bar } \\
{[17, \text { pg } 192,206-210]}\end{array}$ & 0.004 & 0.02 & $\begin{array}{l}\text { buried close to sur- } \\
\text { face in a bundle of } \\
\text { currency bars [England] }\end{array}$ & $\begin{array}{l}\text { Estimate from metal lographic } \\
\text { cross-section. }\end{array}$ \\
\hline 7. & $\begin{array}{l}\text { Iron } \mathrm{Pillar} \text { Delhi } \\
{[26, \mathrm{pg} \mathrm{581]}}\end{array}$ & 0.0001 & 0.001 & $\begin{array}{l}\text { exposed to atmosphere } \\
\text { [India] }\end{array}$ & Estimate from description. \\
\hline 8. & $\begin{array}{l}\text { Corstopitum bloom } \\
{[26, p g 582]}\end{array}$ & 0.2 & $?$ & $\begin{array}{l}\text { found in furnace- } \\
\text { buried in ground } \\
\text { [England] }\end{array}$ & Value quoted. \\
\hline 9. & $\begin{array}{l}\text { Iron sickle } \\
{[39, \mathrm{pg} 428]}\end{array}$ & 0.02 & $<0.08$ & not given [Egypt] & $\begin{array}{l}\text { Estimate from description and } \\
\text { photograph. }\end{array}$ \\
\hline 10. & $\begin{array}{l}\text { Small knife } \\
{[39, \mathrm{pg} 428]}\end{array}$ & 0.005 & $<0.01$ & not given [Egypt] & $\begin{array}{l}\text { Estimate from description and } \\
\text { photograph. }\end{array}$ \\
\hline
\end{tabular}


TABLE 3.1. (contd)

\begin{tabular}{|c|c|c|c|c|c|}
\hline & Artifact Reference \# & $\begin{array}{l}\text { Corrosi } \\
\text { Inches }\end{array}$ & $\begin{array}{l}\text { on Rate } \\
1000 Y R^{(a)}\end{array}$ & Environment & Remarks \\
\hline & & Min. & Max. & & \\
\hline 11 . & $\begin{array}{l}\text { Bronze Handled knife } \\
{[39, \mathrm{pg} \mathrm{428]}}\end{array}$ & 0.005 & $<0.02$ & not given [Egypt] & $\begin{array}{l}\text { Estimate from description and } \\
\text { photograph }\end{array}$ \\
\hline 12. & $\begin{array}{l}\text { Small knife } \\
{[39, \mathrm{pg} 429]}\end{array}$ & 0.005 & $<0.01$ & not given [Egypt] & $\begin{array}{l}\text { Estimate from description and } \\
\text { photograph }\end{array}$ \\
\hline 13. & $\begin{array}{l}\text { Chisel } \\
{[39, \mathrm{pg} 429]}\end{array}$ & 0.005 & $<0.01$ & not given [Egypt] & $\begin{array}{l}\text { Estimate from description and } \\
\text { photograph }\end{array}$ \\
\hline 14. & Hoe $[39, \mathrm{pg} 429]$ & 0.005 & $<0.01$ & not given [Egypt] & $\begin{array}{l}\text { Estimate from description and } \\
\text { photograph }\end{array}$ \\
\hline 15 . & $\begin{array}{l}\text { Axe head } \\
{[39, \mathrm{pg} 429]}\end{array}$ & 0.02 & $<0.08$ & not given [Egypt] & $\begin{array}{l}\text { Estimate from description and } \\
\text { photograph }\end{array}$ \\
\hline 16. & $\begin{array}{l}\text { Axe head } \\
{[39, \mathrm{pg} 429]}\end{array}$ & 0.0001 & $<0.001$ & not given [Egypt] & $\begin{array}{l}\text { Estimate from description and } \\
\text { photograph. Note this specimen } \\
\text { has a blue magnetic oxide coat. }\end{array}$ \\
\hline 17. & Sword [45] & 0.01 & $<0.03$ & not given [Egypt] & $\begin{array}{l}\text { Estimate from photographs and } \\
\text { description }\end{array}$ \\
\hline 18. & Broad axe blade [56] & 0.2 & & $\begin{array}{l}\text { not known } \\
\text { probably some elect- } \\
\text { rochemical corrosion } \\
\text { since in contact with } \\
\text { bronze [China] }\end{array}$ & $\begin{array}{l}\text { Estimate from description and } \\
\text { pictures }\end{array}$ \\
\hline 19. & Dagger axe blade [56] & 0.2 & & $\begin{array}{l}\text { not known } \\
\text { probably some elect- } \\
\text { rochemical corrosion } \\
\text { since in contact with } \\
\text { bronze [China] }\end{array}$ & $\begin{array}{l}\text { Estimate from description and } \\
\text { pictures }\end{array}$ \\
\hline
\end{tabular}


TABLE 3.1. (contd)

Artifact Reference \# $\quad \begin{aligned} & \text { Corrosion Rate } \\ & \text { Inches/1000 YR }(a)\end{aligned}$

Environment

Remarks

Min. Max.

20. Chisel [57, plate 36], 0

0.2

arid climate, buried 7302 (G182)

in tomb [Egypt] - in contact with bronze 21. Chisel [57, plate 36], 0.07
7305 (G585)

0.2 arid climate, buried

in tomb [Egypt]

22. Iron shear [57,

$0.03 \quad 0.06$

plate 36], 7303 (G585)

$\stackrel{\omega}{\infty}$ 23. Key $[57$, plate 36$]$,
7455 (Gi87)

$0.01 \quad 0.02$

arid climate, buried in tomb [Egypt]

Estimate from picture and description

Estimate from picture and description

Estimate from picture and description

arid climate, buried in tomb [Egypt]

Estimate from picture and description

24. Arrowhead [57, plate 35], 7292 (6607)

arid climate, buried in tomb [Egypt]

Estimate from picture and description

25. Chisel [57, plate 36], $0.0001<0.001$ 7367 (G254)

arid climate, buried in tomb [Egypt] Note: was found in

leather bag inside of deteriorated wooden box

26. Iron axe $[57$, plate 36], 7299 (G187)

$0.05<0.15$

in tomb chamber, organic matter close by [Egypt]

27. Iron kohlstick [57, $0.01<0.05$

in tomb chamber, organic matter close by [Egypt]

28. Iron ring [57, plate 33], 8111 (G445)

in tomb chamber, organic matter close by [Egypt]

Estimate from picture and description. (Described as bright as "polished steel" when removed.)

Estimate from picture and description

Estimate from picture and description

Estimate from picture and description 
TABLE 3.1. (contd)

\begin{tabular}{|c|c|c|c|c|}
\hline & Artifact Reference \# & $\begin{array}{l}\text { Corros } \\
\text { Inches } \\
\end{array}$ & $\begin{array}{l}\text { on Rate } \\
1000 \mathrm{YR}^{(a)} \\
\end{array}$ & Environment \\
\hline & & Min. & Max. & \\
\hline 29 . & $\begin{array}{l}\text { Iron ring }[57, \\
\text { plate } 33], 8089 \text { (G384) }\end{array}$ & 0.01 & $<0.02$ & $\begin{array}{l}\text { in tomb chamber, } \\
\text { organic matter } \\
\text { close by [Egypt] }\end{array}$ \\
\hline 30 . & $\begin{array}{l}\text { Iron ring [57, } \\
\text { plate } 33], 8056 \text { (G384) }\end{array}$ & 0.01 & $<0.05$ & $\begin{array}{l}\text { in tomb chamber, } \\
\text { organic matter } \\
\text { close by [Egypt] }\end{array}$ \\
\hline 31. & $\begin{array}{l}\text { Iron kohlstick [57, } \\
\text { plate 33], } 7399 \text { (G384) }\end{array}$ & 0.005 & $<0.01$ & $\begin{array}{l}\text { in tomb chamber, } \\
\text { organic matter } \\
\text { close by [Egypt] }\end{array}$ \\
\hline 32. & $\begin{array}{l}\text { Iron kohlstick }[57, \\
\text { plate } 33], 7383 \text { (G293) }\end{array}$ & 0.005 & $<0.03$ & $\begin{array}{l}\text { in tomb chamber, } \\
\text { organic matter } \\
\text { close by [Egypt] } \\
\text { (buried in sand } \\
\text { above tomb) }\end{array}$ \\
\hline 33. & $\begin{array}{l}\text { Ank lets }[57, \text { plate } 35] \text {, } \\
7379,7376(G 8)\end{array}$ & 0.2 & 0.4 & $\begin{array}{l}\text { in tomb chamber } \\
\text { [Egypt] }\end{array}$ \\
\hline 34 . & $\begin{array}{l}\text { Bucket eye } \\
{[58, \text { plate } 20]}\end{array}$ & 0.2 & & $\begin{array}{l}\text { upper part of Roman } \\
\text { well filling, not } \\
\text { water logged, access } \\
\text { to air [England] }\end{array}$ \\
\hline 35. & $\begin{array}{l}\text { Bucket eye, handle } \\
\text { fragments }[58, \\
\text { plate } 20]\end{array}$ & 0.02 & 0.04 & $\begin{array}{l}\text { lower part of Roman } \\
\text { well filling water- } \\
\text { logged, anerobic } \\
\text { [England] }\end{array}$ \\
\hline
\end{tabular}

Remarks

Estimate from picture and description

Estimate from picture and description

Estimate from picture and description

Estimate from picture and description

Est imate from picture and description

Estimate from picture and description

Estimate from picture and description 


\section{TABLE 3.1. (contd)}

Artifact Reference \# $\begin{gathered}\text { Corrosion Rate } \\ \text { Inches } / 1000 \mathrm{YR}(\mathrm{a})\end{gathered}$

\section{Min. Max.}

36. $\operatorname{Key}[58$, plate 21] $0.005<0.02$

37. Key [58, plate 21]

$0.1<0.2$

38. Key [58, plate 13]

$0.06 \quad 0.4$

0.01

0.03

0.02

0.06

$0.1 \quad 0.2$

0.1

0.2

0.02

0.1

0.06

44. Damascus sword $[61$, plate 6,10$]$
Environment

buried in water logged silt and clay, tannins present may have inhibited corrosion [Engl and]

exposed to air and intermittent water [England]

not given [England]

buried in water-

logged area

not given

not given

not given

not given

not given
Remarks

Estimate from picture and description

Estimate from picture and description

Estimate from picture and $x$-ray photo

Estimate from pictures

Estimate from pictures of cleaned versus partly cleaned sword

Estimate from macrophotos of etched cross-sections

Estimate from macrophotos of etched cross-sections

Estimate from macrophotos of etched cross-sections

Estimate from macrophotos of etched cross-sections

(a) $0.001 \mathrm{in} .=25.4 \mu \mathrm{m}$. 
TABLE 3.2. Copper

$\begin{array}{ll}\text { Artifact Reference \# } & \begin{array}{l}\text { Corrosion Rate } \\ \text { Inches } / 1000 Y R\end{array}(a)\end{array}$

Inches/1000 YR

1. Jericho chisel

$0.01 \quad 0.05$

$[6, \mathrm{pg}$ 123]

2. Bronze sword

[6,pg 193]

$0.005 \quad 0.02$

3. Collar buttons 10

0.06

0.12

4. Effigy of Richard

$0.03 \quad 0.12$ Beauchamp [24]

5. Flanged Bronze Celt [27]

$0.002 \quad 0.01$

6. Bronze celt [29]

0.005

0.02

0.005

0.02

[31, report 1]

8. Bronze halberd [31, report 2]

0.01

0.04

$0.01 \quad 0.04$

$[31$, report 3$]$

10. Bronze halberd [31, report 4] not available

not available

[China]

not available

[Ecuador]

Environment

atmospheric exposure

[England]

buried in sandy clay or gravel within about $2 \mathrm{ft}$ of surface. [England]

buried [Scotland]

unknown [Ireland]

unknown [Ireland]

unknown [Ireland]

unknown [Ireland]
Remarks

Estimate from photographs of cross-section and artifact, apparent ly copper.

Estimate from photograph of sword.

Cu: 40-70 wt pct, remainder Ag. Estimate from macros, crosssections, and description. Cu corroded preferentially

Estimate from photos and decription, bronze.

Estimate from description, 82.73\% Cu, $17.29 \% \mathrm{Sn}$.

Estimate from description, $8 \% \mathrm{Sn}, 0.5 \%$ As

Estimate from description, $0.62 \%$ As, $0.9 \% \mathrm{Sb}$

Estimate from description, $2.6 \%$ As, $0.9 \%$ Sb

Estimate from description, $2.1 \%$ As, $1.66 \mathrm{Sb}$

Estimate from description, 8.11\% Sn, $1.66 \mathrm{Sb}$ 
TABLE 3.2. (contd)

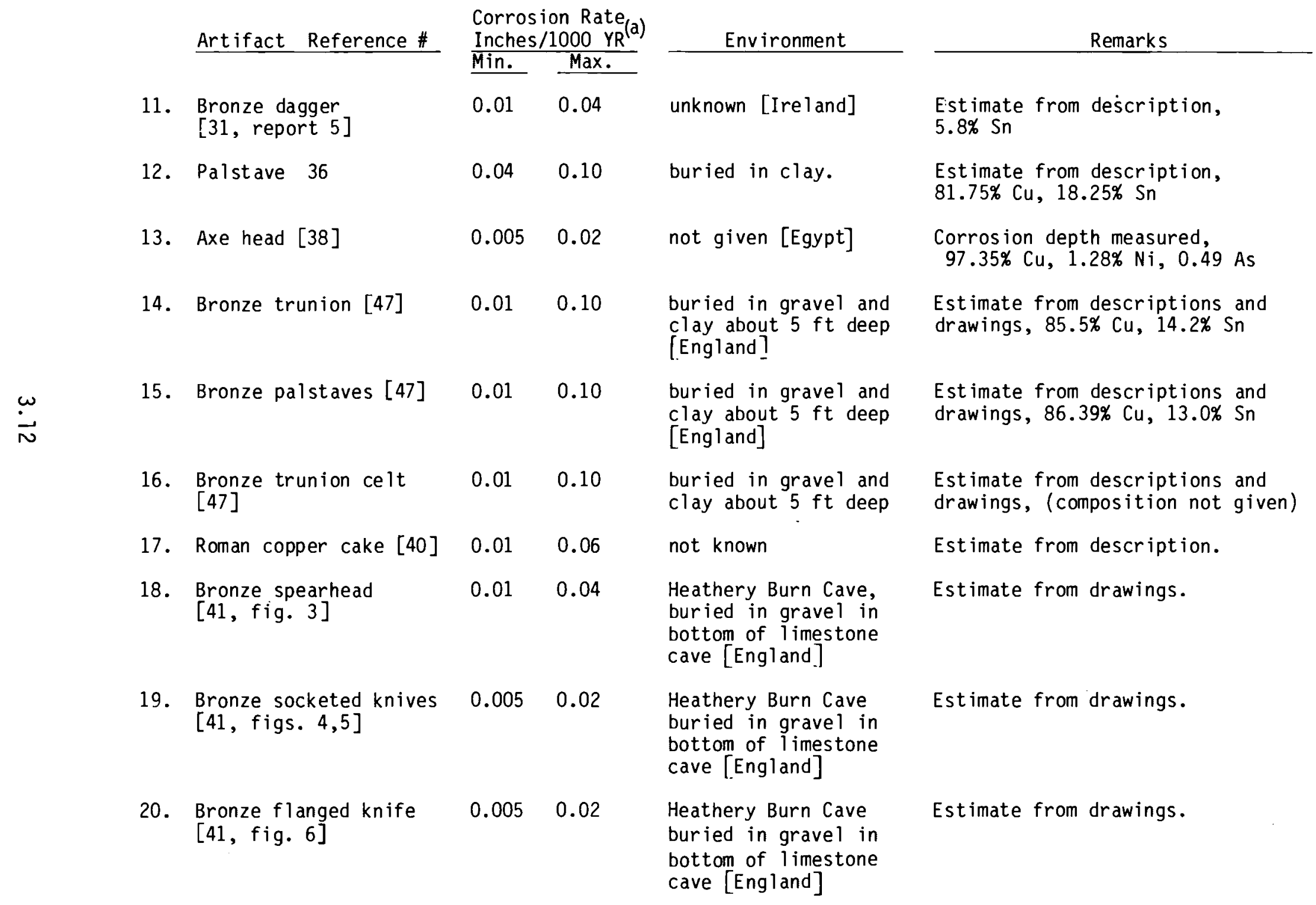


TABLE 3.2. (contd)

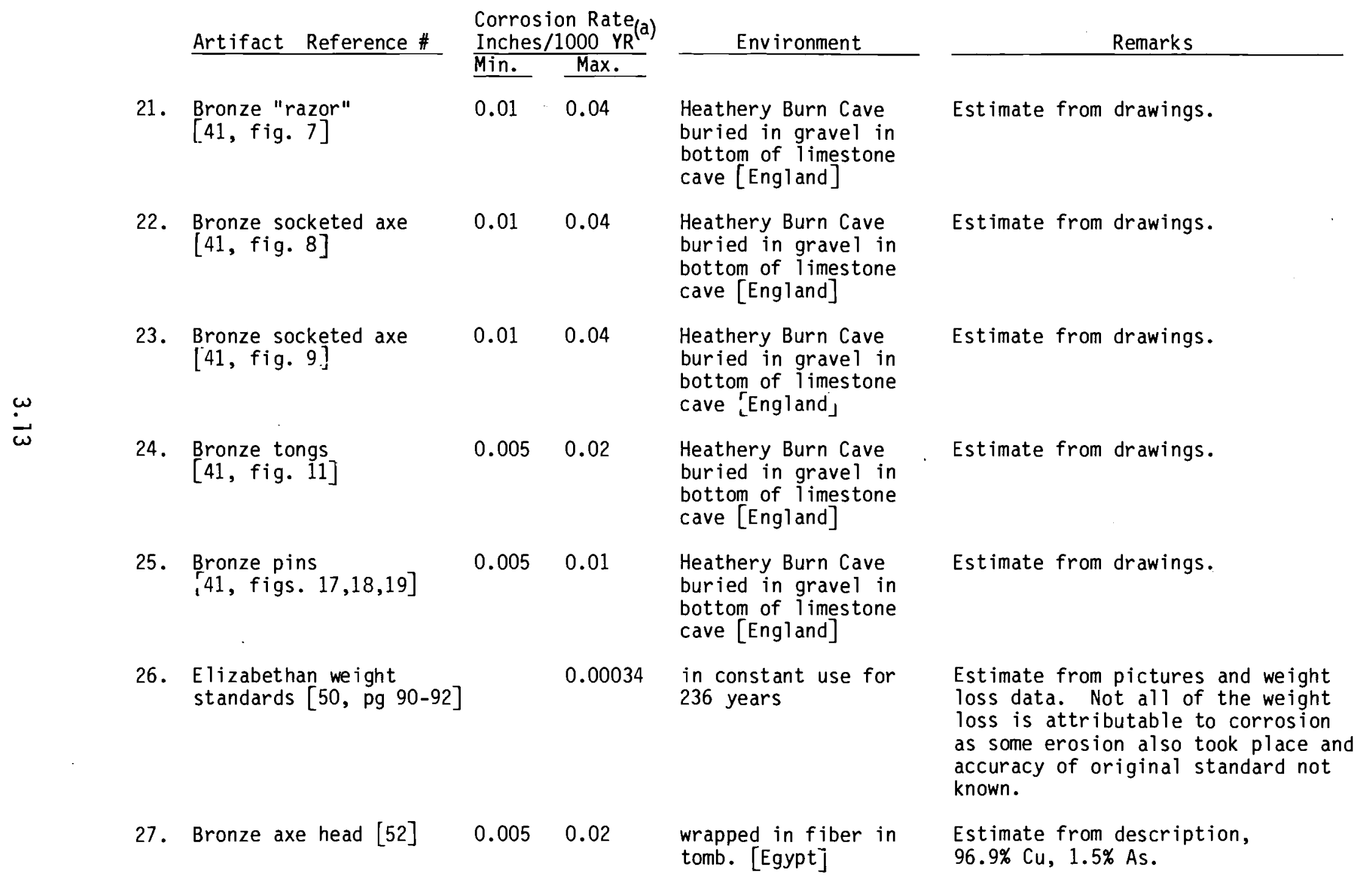


TABLE 3.2. (contd)

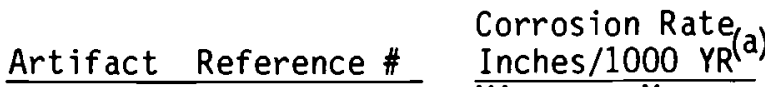
Min. Max.

28. Copper ewer and basin $[53$

29. Whittingham sword [54]

0.001

0.004

$0.0003 \quad 0.001$

30. Brass bosses [55]

$0.002 \quad 0.008$

31. Brass hinges [55]

$0.0005 \quad 0.002$

$\omega$

32. Bronze broad axe [56]

0.002

0.010

33. Bronze dagger axe [56]

$0.001 \quad 0.005$

34. Brass chain mail [58]

0.005

0.02

(a) $0.001 \mathrm{in} .=25.4 \mu \mathrm{m}$. unknown [China]

Environment

not available

[Egypt]

Found in a bog. rEngland]

buried $14 \mathrm{ft}$ under surface, "dry" [England] some

leather attached.

buried $14 \mathrm{ft}$ under surface, "dry" [England] some leather attached.

unknown. [China] [England] not available
Remarks

Estimate from pictures and description.

Estimate from pictures and description. Bronze. Described as in nearly perfect condition when found.

Estimate from description and pictures.

Estimate from description and pictures.

Estimate from description, pictures, micrographs, chemica 1 analyses, and radiographs. In some areas at least appears to be entirely penetrated by $\mathrm{Cu}_{20} \mathrm{O}$ on grain boundaries. Corrosion rate estimate is for general corrosion.

Estimate from description, pictures, micrographs, chemical analyses, and radiographs. In some areas at least appears to be entirely penetrated by $\mathrm{Cu}_{2} \mathrm{O}$ on grain boundaries. Corrosion rate 85.5\% Cu, 12.2\% Sn, 2.1\% Pb estimate is for general corrosion.

Estimate from picture and description. 
TABLE 3.3. Lead

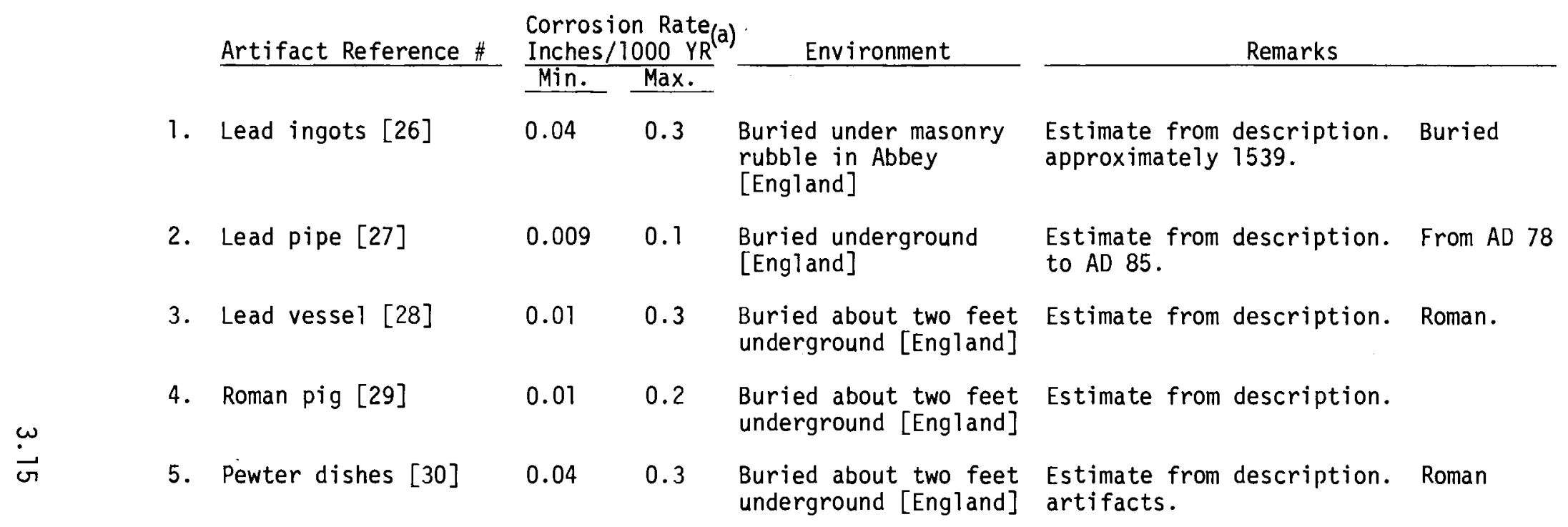

(a) $0.001 \mathrm{in.}=25.4 \mu \mathrm{m}$. 
TABLE 3.4. Atmospheric Corrosion Rates from Modern Experience (from Ref. 31)

\begin{tabular}{lcc}
\multicolumn{1}{c}{ Material } & \multicolumn{2}{c}{ Corrosion Rate inches $/ 1000 \mathrm{yr}$} \\
$\mathrm{Cu}$ & & $\frac{\min .}{\max .}$ \\
$\mathrm{Pb}$ & 0.017 & 0.054 \\
$\mathrm{Fe}$ (carbon steel) & 0.073 & 0.021 \\
0.001 in. $=25.4 \mu \mathrm{m}$ & & 0.48
\end{tabular}




\subsection{REFERENCES}

1. Corrosion and Metal Artifacts: A Dialogue Between Conservators and Archeologists and Corrosion Scientists. Ed. by B. F. Brown, et al., PB-273 116, 1977.

2. C. A. Smith. "Early Corrosion Investigations." Corrosion Prevention and Control, February 1977, 6-13.

3. R. F. Tylecote. Metallurgy in Archeology. London, Edward Arnold Ltd.

4. H. C. Richardson. "Iron, Prehistoric and Ancient." Amer. J. Arch. Vol. $38,1934,555$.

5. H. C. H. Carpenter and J. M. Robertson. "The Metallography of Some Ancient Egyptian Implements." Visi. Vor. 121, 417-54.

6. H. H. Coghian. "A Note Upon Iron as a Material for the Celtic Sword." Sibrium. Vol. 3, 1956-7, 129-36.

7. R. J. Gettens, R. S. Clarke, Jr., and W. T. Chase. "Two Early Chinese Bronze Weapons with Meteoritic Iron Blades." Free Gallery of Art Occasional Papers. Vor. 4, No. 1, 1971.

8. C. L. Woolley and D. Randal1-MaCiver. "Eckley B. Coxe Junior Expedition to Nubia: Vol. IV, Karanog, the Romana-Nubian Cemetery." University of Pennsylvania University Museum, Philadeiphia, PA, MCMX.

9. L. Biek. Archeology and the Microscope. Lutterworth Press, London, 1963.

10. E. Salin. La Civilisation Mérouingienne. J. Picard, Paris, 1957.

11. J. L. McCall and R. D. Buchheit. "Metallographic Studies of Archeological Artifacts from Ecuador." Metallography. Vol. 4, 1971, 209-222.

12. J. N. Friend and W. E. Thorneycraft. "Examination of a Fifteenth-Century 'Brass'." J. of the Institute of Metals. Vol. 37, 1927, 71-73.

13. A. Raistrick and J. A. Smythe. "A Flanged Bronze Celt from Birtley, Co. Durham." Proc. Un. Durham Phil. Society, Vol. 9, No. 2, 1931-37, 47-54.

14. E. Voce. "Ancient Mining and Metallurgy Committee: Report on the Examination of a Broken Celt from Scotiand." Man. Vo1. 51, No. 6, 1957, 6-7.

15. T. K. Penniman and I. M. Allen, "A Metallurgical Study of Four Irish Early Bronze Age Ribbed Laiberds in the Pitt Rivers Museum, 0xford." Man. Vo1. 60 , No. $120,1960,85-89$. 
16. C. G. Read. "Hoard from Southal1, Middlesex, and Other Places." Society of Antiquaries of London Proceedings. Series 2, Vol. 16, 1895-7, $\overline{327-334 .}$

17. H. C. H. Carpenter. "An Egyptian Axe Head of Great Antiquity." Nature. Vol. 130, October 1932, 625-626.

18. L. F. Chitty. "Three Bronze Implements from the Edgehold Brickyard, Meole Brace, Shropshire." Antiquaries Journal. Vol. 5, 1925, 409-414.

19. W. 0. Stanley. "Notes on Vestiges of Roman Workings for Copper in Anglesey." Archeological Journal. Vol. XXV, 1873, 59-62.

20. W. Greenwe11. "Antiquities of the Bronze Age found in the Heathery Burn Cave, County Durham." Archeologia. Vol. XIV, 1894, 87-114.

21. R. E. Zupko. British Weights and Measures, a History from Antiquity to the Seventeenth Century. University of Wisconsin Press, 1977.

22. H. C. H. Carpenter. "An Egyptian Axe-head of Date 1800 BC: Its Investigation and Reproduction." Letter to the Editor, Nature. Vol. 127, Apri1 1931, 589-591.

23. C. G. Fink and A. H. Kopp. "Ancient Egyptian Antimony Platting on Copper Objects." Metropolitan Museum Studies IV, 1933, 163-167.

24. J. D. Cowen and H. Maryon. "The Whittingham Sword." Arch. Ael. Vol. 12, $1925,280-309$.

25. G. E. Fox, M. A. Oxon, and W. H. St. John. "Excavations on the Site of the Roman City at Silchester, Hants, in 1900." Archeologia. Vol. 57ii, $1900,229-256$.

26. C. G. Dunning. "A Lead Ingot at Rievaulx Abbey." Antiquaries Journal. $32: 199-202,1952$.

27. Anonymous. "Lead Pipe from Chester." Society of Antiquaries of London, Proceedings. 18:96-98, 1899-1901.

28. H. E. Donovan. "Excavations at Bouston on the Water." Trans. Bristol and Glos. Arch. Soc. 55:377-382, 1933.

29. E. Davies. "Discovery of a Roman Lead Pig in Flintshire." Arch. Camb. 101:83-84, 1950 .

30. J. Liversidge. "A New Hoard of Romano-British Pewter from Deklingham." Proc. Camb. Ant. Soc. 52:6-10, 1959.

31. H. H. Uhlig. Corrosion and Corrosion Control. 2nd ed., John Wiley and Sons, Inc., New York, NY, p. 165-166, 1971. 


\subsection{DURABILITY OF METAL METEORITES}




\subsection{DURABILITY OF METAL METEORITES}

Over geologic history, numerous cosmic bodies called meteorites have entered the earth's atmosphere, been heated to luminosity on the meteorite surface, finally falling to the earth's surface. The two major meteorite varieties are stony and metallic (iron). This treatment will focus on the metal meteorites. Table 4.1 indicates that 532 metal meteorites have been recovered worldwide. The meteorites are iron-nickel alloys. They have three major classifications (Table 4.1 ) based on nickel content: hexahedrites, octahedrites, and ataxites. The octahedrites are characterized by the cross-hatched Widmanstätten structure. The meteoritic Widmanstätten structure develops by solid state diffusion at low temperatures over very long times.

The principal minerals in the metal meteorites are taenite and kamacite (Table 4.1), though approximately 45 mineral species have been identified in one or more of the 500 metal meteorites (Ref. 1, p. 88).

Meteorites are named after geographic locations near where they were found.

Buchwald has published an excellent 3-volume treatise which focuses on the metal meteorites. (1) The work includes descriptions of essentially all the metal meteorites.

\subsection{METEORITE AGES}

\subsubsection{Cosmic Ages}

The cosmic age of a meteorite is the time since the meteoritic material separated from the parent body. The parent body ages are believed to be 4 to 4.5 billion years. (1) The age of individual meteorites since separation from the parent body is estimated by determination of isotope ratios (e.g., ${ }^{38} \mathrm{Ar} /{ }^{39} \mathrm{Ar}$, ${ }^{41} \mathrm{~K} /{ }^{40} \mathrm{~K}$ ) which reflect cosmic ray bombardment of the meteorite. Ref. 1, p. 142 discusses the variations of cosmic age determinations. Estimates of cosmic ray exposure ages on numerous metal meteorites range from $1 \times 10^{6}$ to $2,000 \times$ $10^{6}$ years. 
TABLE 4.1. Metal Meteorites - Summary of Data

Number of Metal Meteorites

532

Fal1s (a)

32

Finds

500

Metal Meteorite Sizes

Most Common Masses Recovered

Largest (est.)

Smallest

$10-40 \mathrm{~kg}$

$60,000 \mathrm{~kg}$

$0.16 \mathrm{~kg}$

Metallurgical Classification

Hexahedrites

Octahedrites

4-6 wt\% Ni

$6-12 \mathrm{wt} \% \mathrm{Ni}$

Ataxites

$>12 \mathrm{wt} \% \mathrm{Ni}$

Most Common Minerals

Taenite (Nickel-Austenite, $>25 \mathrm{wt} \% \mathrm{Ni}$ )

Kamacite (Nickel-Ferrite, $<7.5 \mathrm{wt} \% \mathrm{Ni}$ )

Plessite (Intergrowth of Kamacite and Taenite)

Cubic, Fe-Ni

Cubic, low $\mathrm{Ni}$

$\mathrm{High} \mathrm{Ni}$

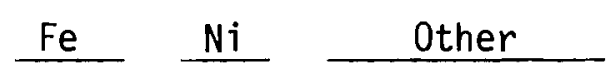

Composition

Most Frequent Range wt\%

Maximum Ni, wt\%

Mean Nickel, wt\%

Cobalt, wt\%

Chlorine, ppm, wt

Titanium and Vanadium, ppm, wt

Chromium, ppm, wt

Manganese, ppm, wt

89-95 5-11

60

7.9
$0.3-1.0$

$1-10$

$0.5-5.0$

$<5-2,500$

$10-20$

(a) Meteorites which fell to earth under human observation. 


\subsubsection{Terrestrial Ages}

Time on earth or terrestrial age is important to assessments of meteorite corrosion. Only a fraction of the metal meteorites have known or even estimated ages. Meteorites with known or estimated ages are plotted in Figure 4.1. Dating the metal meteorites has several levels of definition. The categories of meteorite dating are discussed below.

The Falls

Because the 32 falls occurred under human observation their terrestrial ages are precisely defined, except for one or two still in question. The ages vary from 10 to 240 years (in 1979). Terrestrial ages of the falls are plotted in Figure 4.1.

\section{Crater Dating}

Several large metal meteorites have formed craters upon impact. Perhaps the best known is the Canyon Diablo crater in Arizona, formed by a metal meteorite which has yielded metal masses totalling $\sim 30,000 \mathrm{~kg}$. The crater diameter is $\sim 1,200 \mathrm{~m}$. Geologic dating of the craters provides an estimate of the terrestrial age of the meteorites. Table 18 of Ref. 1 summarizes the crater-forming metal meteorites. They are also plotted on Figure 4.1, varying from $<5,000$ to $>100,000$ years.

\section{Radiocounting}

The terrestrial ages of some metal meteorites have been estimated by radiocounting. When a meteorite penetrates the earth's atmosphere, it is subsequently shielded from further significant cosmic ray bombardment. The terrestrial age is then calculated from the decay equation $N=$ No $e^{-\lambda t}$. Isotopes which are analyzed to determine $\mathrm{N}$ include ${ }^{3} \mathrm{H}(\tau=12.3 \mathrm{y}),{ }^{39} \mathrm{~A}(\tau=326 \mathrm{y}),{ }^{14} \mathrm{C}(\tau=$ $5,700 y)$, and ${ }^{36} \mathrm{Cl}\left(\tau=0.31 \times 10^{6} \mathrm{y}\right)$. The decay constant, $\lambda$, is $0.692 / \tau$ where $\tau$ is the half-life, and $t$ is the terrestrial age. The value of $N_{0}$ for a given isotope is calculated from the levels of long-lived isotopes, such as ${ }^{26} \mathrm{Al}(0.7$ $x 10^{6} \mathrm{y}$ ), in the meteorite and from calibrations on freshly-fallen meteorites. Three meteorites with ages estimated by radiocounting are plotted on Figure 4.1. 


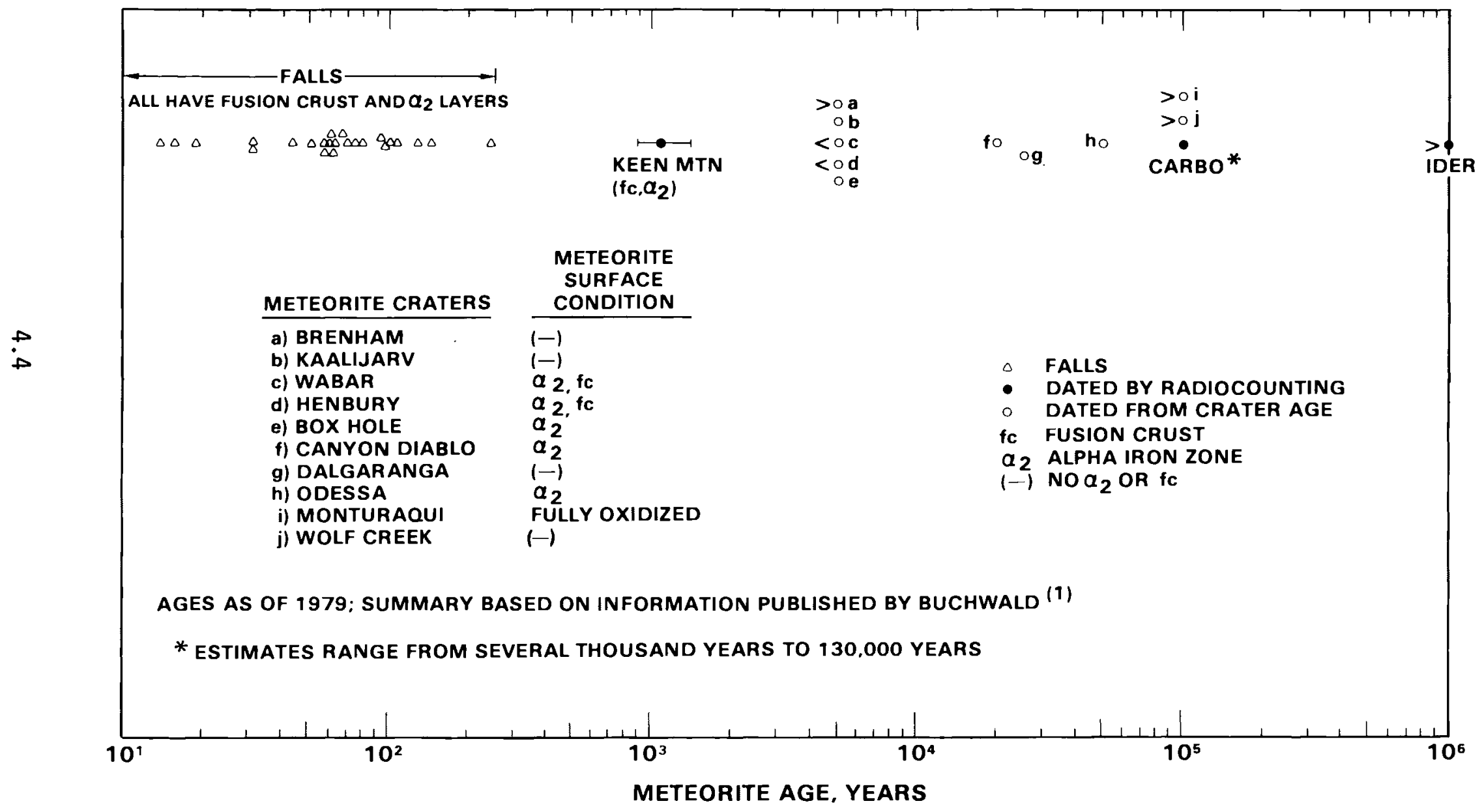

FIGURE 4.1. Metal Meteorites With Known or Estimated Terrestrial Ages 
Carbo is plotted at $\sim 100,000$ years, based on the ${ }^{10} \mathrm{~B} /{ }^{36} \mathrm{Cl}$ method. However, ${ }^{14} \mathrm{C}$ and ${ }^{39} \mathrm{Ar}$ counting suggested much lower ages. Chang and Wänke ${ }^{(2)}$ have estimated ages of several iron meteorites by radiocounting. Mason (Ref. 3, p. 190) observed that high estimated terrestrial ages of some meteorites suggest that meteoritic irons weather slowly. However, we shall see that weathering rates depend on several important factors.

\section{Venerated Meteorites or Artifacts}

There is another class of metal meteorites or sections of meteorites which have been a part of human activities for centuries, the so-called venerated meteorites. Buchwald 1ists 24 cases; 6 involved meteorite fragments and archaeological artifacts of suspected meteoritic origin. The archaelogical materials include iron beads from Gerzeh, Egypt, dating to $23000 \mathrm{BC}$; also two corroded oval blades found at Ur (Iraq), dated to $22500 \mathrm{BC}$. Buchwald indicates that meteoritic origin is not conclusive. However, the onset of iron smelting appeared to be much later (see Figure 2.1, Section 2.1).

Fifteen of the remaining venerated meteorites involved complete specimens which were worshiped, included in gravesites, etc. The history of veneration covers the period 1100 to $1871 \mathrm{AD}$. The fact that the meteorites have survived for up to $\leadsto 9$ centuries is significant, though the total terrestrial age is not known.

\subsection{WEATHERING OF IRON METEORITES}

\subsubsection{Features Which Index Degree of Weathering}

As meteorites enter the earth's atmosphere, they are traveling at 10 to $70 \mathrm{~km} / \mathrm{sec}$. (1) The meteorite temperature is $10 \mathrm{w}\left(20^{\circ} \mathrm{C}\right)$ as it enters the atmosphere. Approximately 90 to $120 \mathrm{~km}$ above the earth, the meteorite surface is heated to luminosity due to atmospheric friction. During the luminous period, the meteorite surface is oxidized by reaction with the atmosphere. The surface undergoes ablation, as melting metal and oxide escape from the surface. A thin layer of metal immediately under the oxide is heated above a transformation temperature, forming an $\alpha_{2}$ iron zone. 
Approximately 8 to $16 \mathrm{~km}$ above the earth, the denser atmosphere slows the smaller meteorites, luminosity ceases, and the meteorite cools as it drops to earth. Large meteorites maintain a major fraction of their cosmic velocities, and sometimes cause severe cratering upon impact.

Three features formed during the luminous phase are useful to index the degree of terrestrial weathering on the meteorites:

1. The Fusion Crust - an oxide composed of magnetite $\left(\mathrm{Fe}_{3} \mathrm{O}_{4}\right)$ and wustite $\left(\mathrm{Fe}_{1-\mathrm{x}} \mathrm{0}\right)$. The oxide sometimes incorporates some fused metal. The magnetite wustite thickness is typically $50 \mu \mathrm{m}$ (Ref. 1, p. 52). In Figure 4.2, the minimum fusion crust thickness is $40 \mu \mathrm{m}$ for the N'Kandhla meteorite. The cusp-like appearance may be due to effects of ablation. Figure 4.3 (Rembang) is another example of a meteorite with a fusion crust $(50 \mu \mathrm{m})$. In this case, metal particles are incorporated in the oxide, probably from melting during the ablation phase.

2. The $\alpha_{2}$ Iron Zone - a rim of heat-altered metal immediately under the fusion crust. The general thicknesses for the $\alpha_{2}$ iron are $2.0 \pm 0.5 \mathrm{~mm}$ (leading edge) to $4 \pm 1 \mathrm{~mm}$ (rear surfaces). (1) The $\alpha_{2}$ iron zones are apparent on the $\mathrm{N}^{\prime}$ Kandhla and Rembang meteorites (Figures 4.2 and 4.3), comprising several sublayers. The maximum $\alpha_{2}$ layer thickness is $0.09 \mathrm{~mm}$. On Figure 4.3 , the $\alpha_{2}$ zone thickness is $0.25 \mathrm{~mm}$.

3. Regmaglypts - rounded indentations which form during the ablation process. Flow lines (flutings) are another ablation feature which are apparent on some meteorites. Figure 4.4 shows an example of a relatively ancient meteorite which has residual regmaglypts.

Meteorites, particularly the large ones, fragment during entry through the atmosphere. On fragments which form during the last stages of heating, the fusion crust and $\alpha_{2}$ layers may be very thin. There are also suggestions that a very thin fusion crust may occur on some shock-heated fragments formed on impact (Ref. 1, p. 395).

If the fusion crust and $\alpha_{2}$ iron layers are intact, this indicates absence of significant weathering. Some meteorites have lost the fusion crust, but retain the $\alpha_{2}$ zone. 


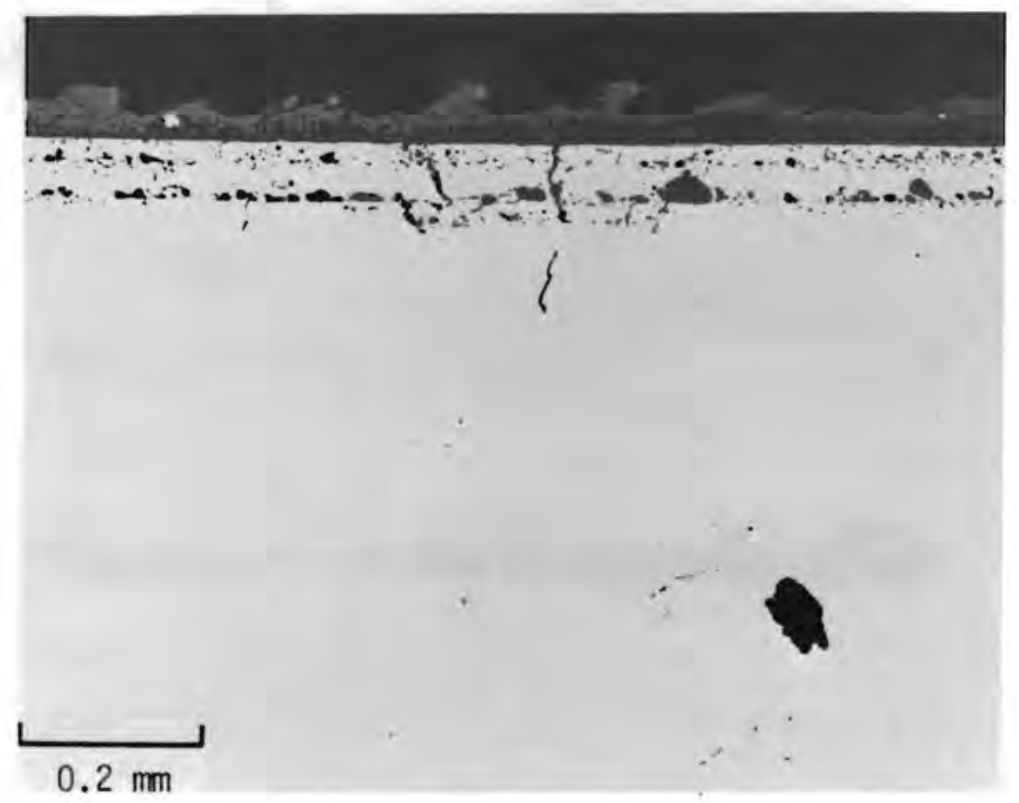

a. As-polished, Neg. No. 4P1072E, Mag. 100X

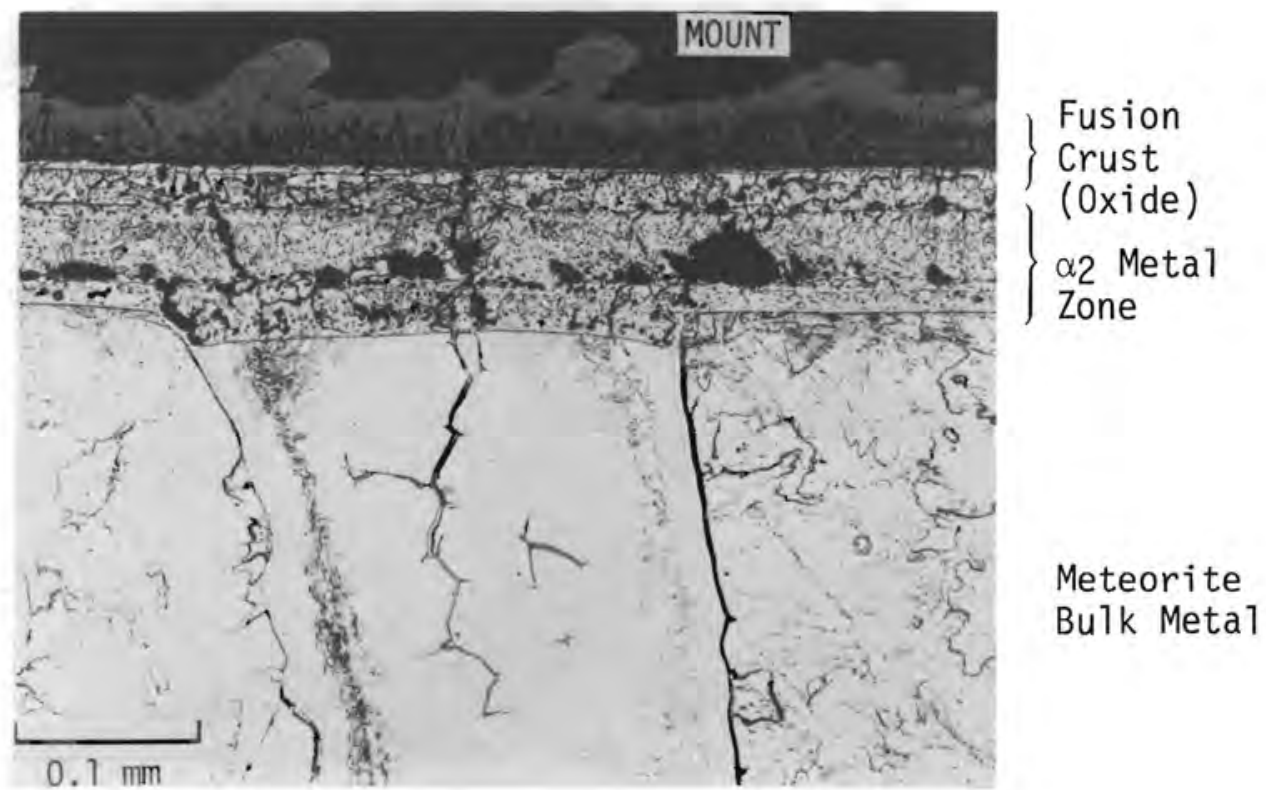

b. Etchant: 2\% Nita1, Neg. No. 4P1072L, Mag. $200 \mathrm{X}$

FIGURE 4.2. Metallographic Sections of N'Kandhla Meteorite (Fall): Fell in South Africa, August 1, 1912; Section Supplied By E. 01sen, Field Museum, Chicago; Metallography by R. Beauchamp, Battelle, PNL, July 1979. Composition: (1) $9.96 \% \mathrm{Ni}, 0.64 \% \mathrm{Co}$, About $0.3 \% \mathrm{P}, 71 \mathrm{ppm} \mathrm{Ga}, 83 \mathrm{ppm} \mathrm{Ge}$, $18.5 \mathrm{ppm}$ Ir, Remainder Fe 


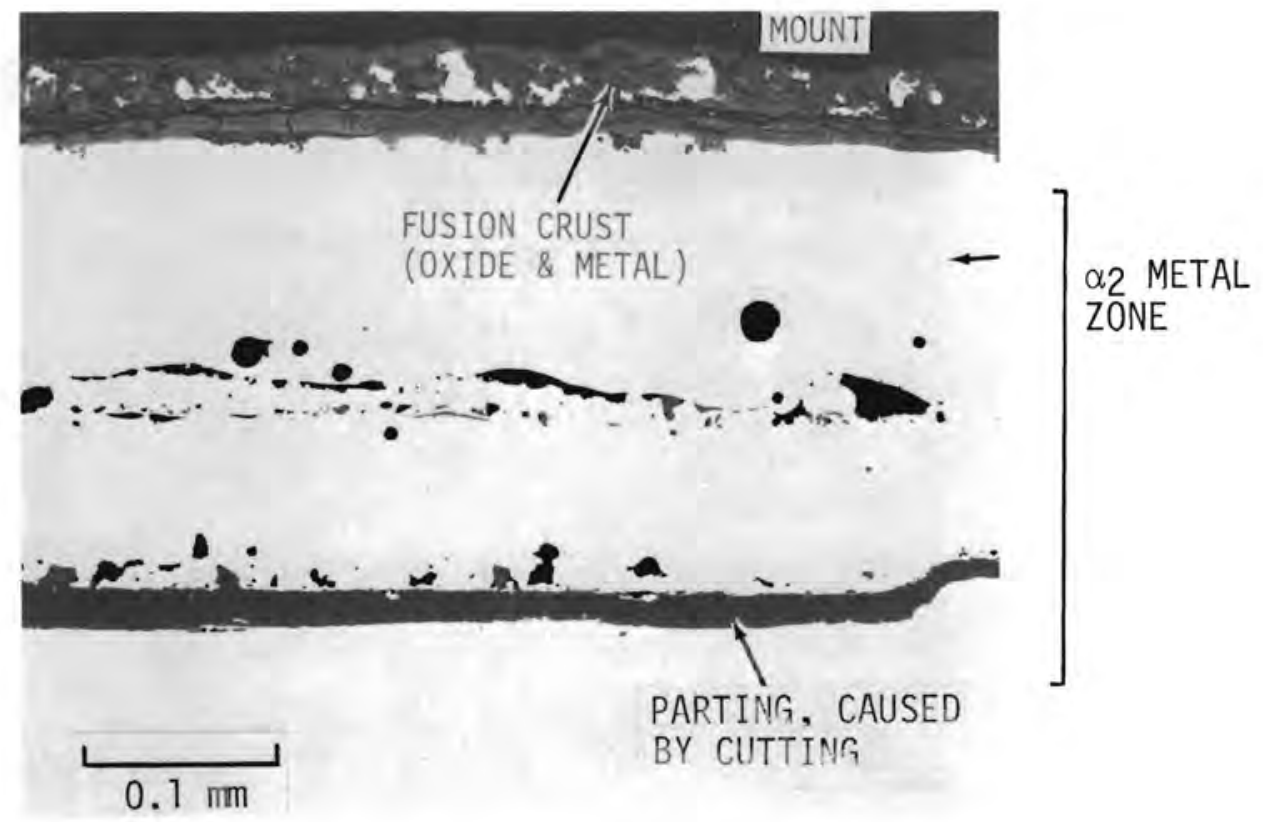

a. As-polished, Neg. No. 4P1071H, Mag. 200X

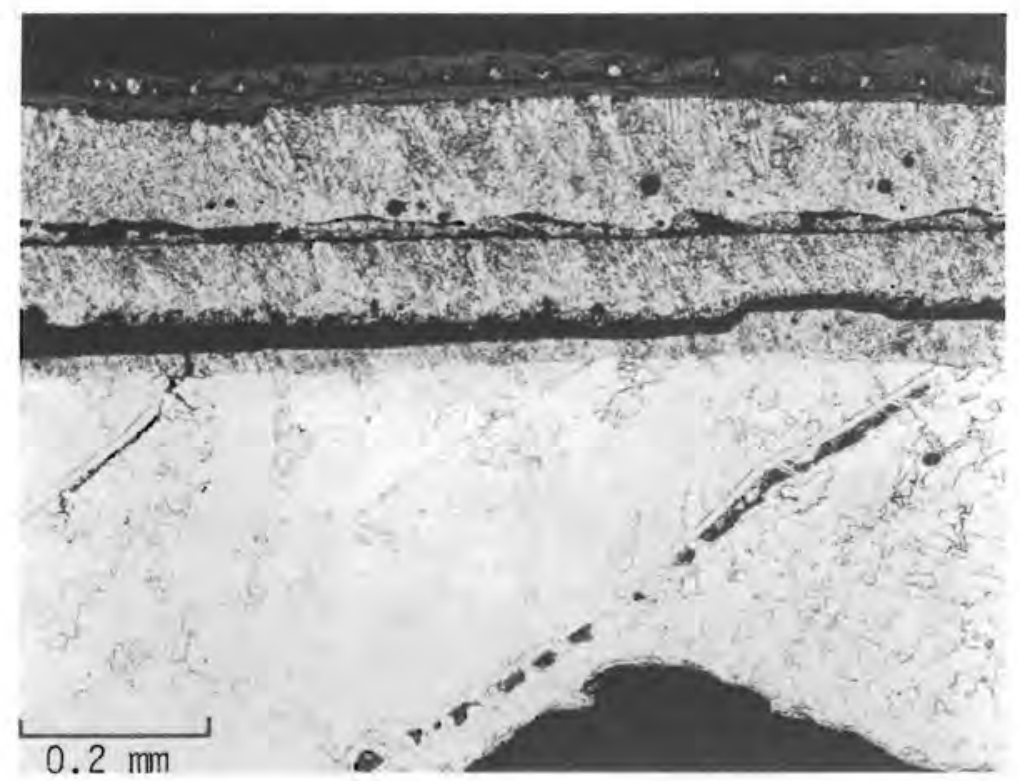

b. Etchant: 2\% Nital, Neg. No. 4P1071N, Mag. 100X

Figure 4.3. Metallographic Sections of Rembang Meteorite (Fal1): Fel1 in Indonesia, August 30, 1919; Section Supplied by E. Olsen, Field Museum, Chicago; Metallography by R. Beauchamp, Battelle, PNL, July 1979. Composition: (1) $8.82 \% \mathrm{Ni}, 2.25 \% \mathrm{Ga}, 0.13 \mathrm{ppm} \mathrm{Ge}, 1.2 \mathrm{ppm} \mathrm{Ir}$. Remainder Fe 


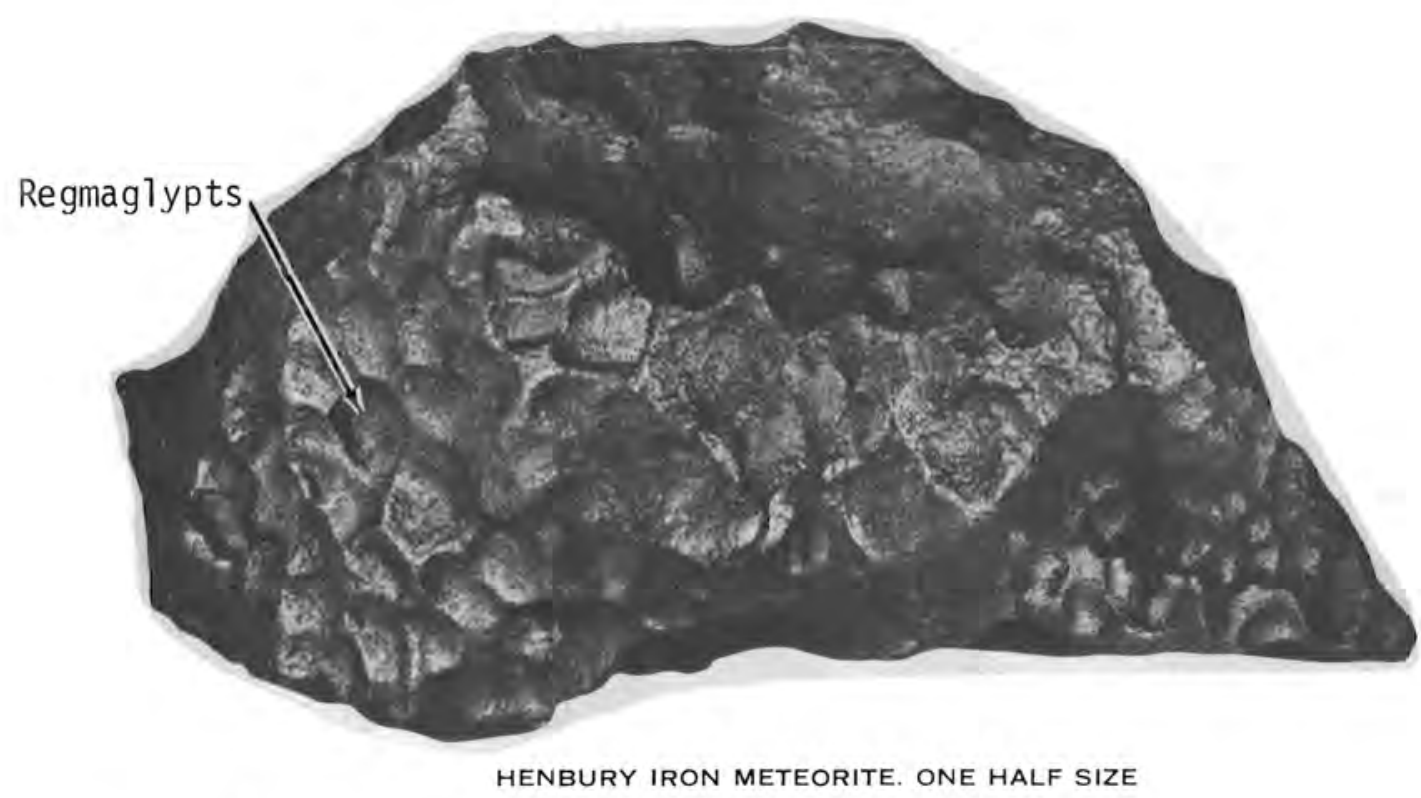

FIGURE 4.4. Henbury Meteorite - Photograph Courtesy of Prof. C. B. Moore, Arizona State University. Fell in the Northwest Territory, Australia; Discovered in 1931. Estimated Terrestrial Age, 25,000 Years. Composition: $7.51 \% \mathrm{Ni}, 0.45 \mathrm{Co}, 0.09 \mathrm{P}, 18 \mathrm{ppm}$ $\mathrm{Ga}, 34 \mathrm{ppm} \mathrm{Ge}, 13 \mathrm{ppm}$ Ir. Remainder Fe

Note the rounded indentations (regmaglypts) formed by ablation during descent through the earth's a tmosphere. 


\subsubsection{Observations on the Degree of Meteorite Weathering}

of the 480 metal meteorites which have been examined for fusion crusts and $\alpha_{2}$ iron layers, 146 have both fusion crust and $\alpha_{2}$ zones; 230 have only $\alpha_{2}$ zones. (1) Thus, over half of the known iron meteorites have undergone minimal weathering. Some partially-buried meteorites have weathered substantially on surfaces exposed to the soil, with minimal weathering on surfaces exposed to the atmosphere, indicated by residual fusion crust or $\alpha_{2}$ zones.

The presence or absence of fusion crusts and $\alpha_{2}$ iron is indicated on Figure 4.1 for the meteorites with known or estimated ages. According to Buchwald, 25 of the falls have been analyzed and all continue to show fusion crusts and $\alpha_{2}$ iron layers, over the time period of 210 to 240 years.

The falls come from a variety of geographic locations. However, the falls presumably were recovered soon after impact and probably have been stored in museums or other buildings. They would have been contaminated (chlorides, skin oils, etc.) from human handling and cutting, sometimes in water. Otherwise, they would be exposed in a variety of museum environments.

For the meteorites dated from the estimated age of their craters or from radioactive counting, some have survived we1l, while others are in advanced stages of weathering. The following section will describe the stages of weathering and show examples of meteorites representing the various stages.

\subsubsection{Stages of Meteorite Weathering}

For the purposes of this discussion, we will identify five stages of meteorite weathering. Some large meteorites which separated into numerous masses have specimens in essentially all five stages of weathering. Factors which contributed to the differences in degree of weather will be discussed.

\section{Stage 1 - Fusion Crust and $\alpha_{2}$ Layers Identifiable}

Descriptions given by Buchwald ${ }^{(1)}$ suggest that all of the falls continue to show fusion crust and $\alpha_{2}$ zones (Section 4.2.1). We have previously alluded to Figures 4.2 and 4.3 , as examples of well-preserved fusion crust and $\alpha_{2}$ zones. Buchwald identifies approximately 120 metal meteorites which have both fusion crust and $\alpha_{2}$ layers on at least part of the surface. These include several 
relatively ancient meteorites. Henbury, found in Northern Territory, Australia (Figure 4.4), and Wabar found in Saudi Arabia, are estimated to be $\checkmark 5,000$ years old, based on geologic dating of their craters. Some masses from these meteorites have areas still in Stage 1 weathering. Similarly for Keen Mountain, Virginia, USA, with an estimated (radiocounting) age of $\sim 1,000$ years and Navajo, apparently known to and considered sacred by the Navajo Indians since $21600 \mathrm{AD}$. The Bagdad (Arizona, USA) meteorite (Figure 4.5) is a borderline Stage 1, having a clearly evident $\alpha_{2}$ layer, but still retaining less obvious remnants of the fusion crust.

Another interesting example of Stage 1 weathering is the Allan Hills 76-02 octahedrite (1,510 grams) found on Antarctica ice. ${ }^{(4)}$ It was the only iron found with a group of ten chrondrites and achondrites (stony meteorites). The stony meteorites have been dated (radiocounting) at $210^{5}$ years, except for one (76-08) with an estimated terrestrial age of $1.7 \times 10^{6}$ years. There is speculation that the meteorites have been carried in the glacial ice, surfacing when forced up by a rock barrier.

Allan Hi11s 76-02 has we11-preserved fusion crust and $\alpha_{2}$ zones totaling $\checkmark 4 \mathrm{~mm}$. It has weathered hardly at a11 in the Antarctic environment. Association with the dated stony meteorites suggests that it may be ancient, but that must remain speculative until Allan $\mathrm{Hills} 76-02$ is dated independently.

Stage 2 - Fusion Crust Missing $-\alpha_{2}$ Layer Identifiable

Buchwald identifies 85 meteorites with $\alpha_{2}$ zones on at least part of the surface. (a) Among them are specimens from some meteorites which formed craters:

- Boxhole (Australia), estimated to be 25,000 years old, has at least one specimen with a $2 \mathrm{~mm}$-wide $\alpha_{2}$ zone.

- Canyon Diablo (Arizona, USA); many of the unshocked large metal masses have retained the regmaglypts and $\alpha_{2}$ zones. The $\alpha_{2}$ zones are missing from shocked and shock-annealed Canyon Diablo masses because the masses appear to have formed upon impact. The Canyon Diablo crater is estimated to be at least 20,000 years old.

(a) This is in addition to 120 meteorites with both fusion crust and $\alpha_{2}$ zones. 


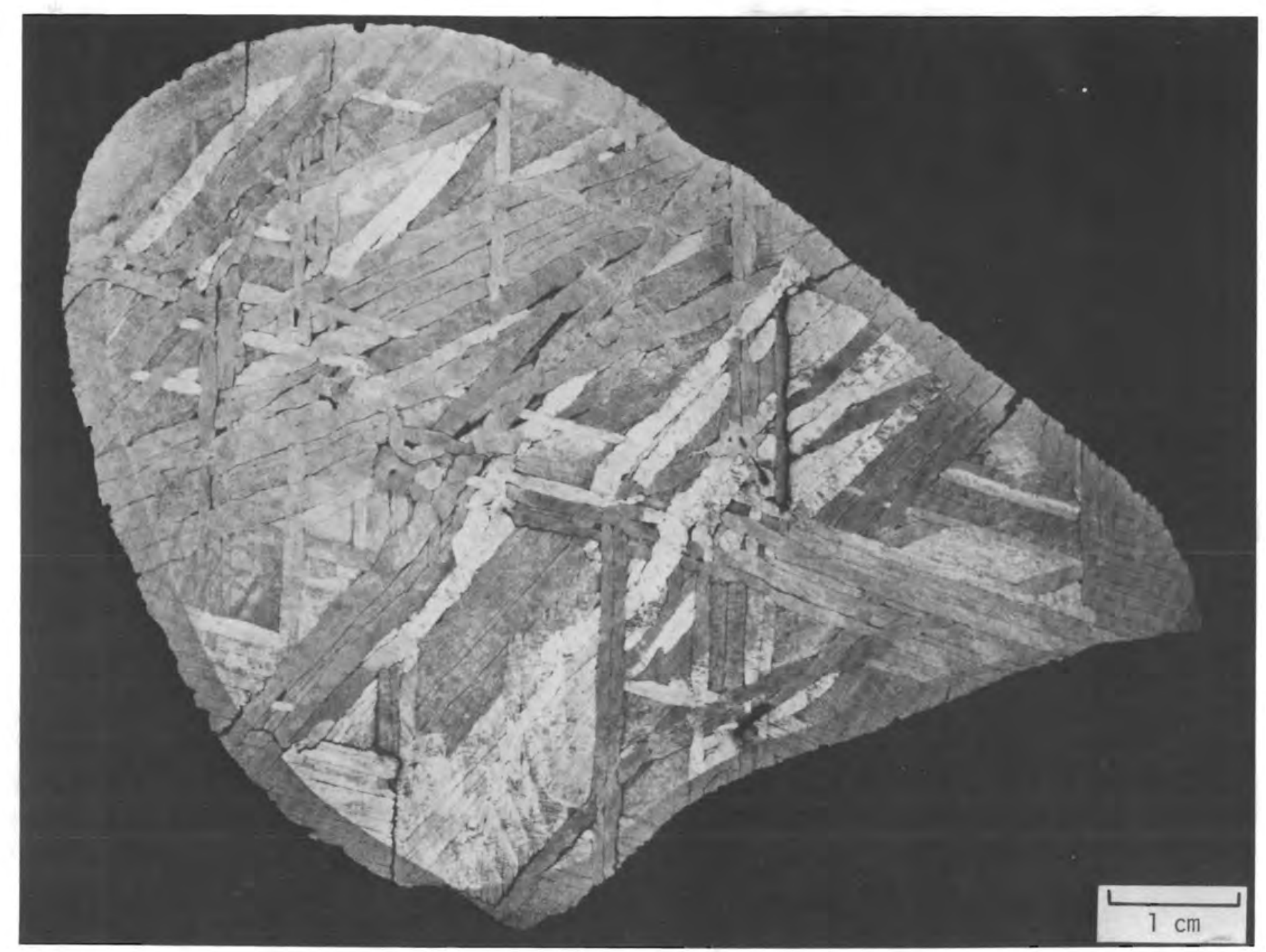

FIGURE 4.5. Bagdad Meteorite, Photo Courtesy of Prof. C. B. Moore, Arizona State University, Fel1 in Arizona, USA, Discovered in 1960 . Composition: (1) $8.17 \% \mathrm{Ni}, 0.45 \% \mathrm{Co}$, $0.12 \%$ P. $19.8 \mathrm{ppm} \mathrm{Ga}, 39.7 \mathrm{ppm}$ Ge, $6.8 \mathrm{ppm} \mathrm{Ir}$, Remainder Fe. 
- Odessa (Texas, USA) is estimated to be $\sim 50,000$ years $01 d$, based on both radiocounting and archaeological evidence. (1) Heat-affected zones (up to 1-2 mm thick) have been identified on some specimens, though the zones are irregular.

Stage 3 - Meteorite Largely Metallic, Fusion Crust and $\alpha_{2}$ Layers Missing

Of the 480 meteorites which have been analyzed, about 230 have no evidence of residual $\alpha_{2}$ zones. Yet, a large fraction have sizable masses of metal remaining.

Figure 4.6 shows a cross section of a small Canyon Diablo specimen which we have examined. There is no evidence of residual fusion crust and $\alpha_{2}$ zone, but considerable metal remains. Note also that numerous metal particles are incorporated in the oxide, having resisted corrosion over the estimated 20,000 year Canyon Diabalo terrestrial 1ife. The compositions of the resistant phases in the oxide, from electron microprobe analysis are:

$\sim 75 \mathrm{wt} \% \mathrm{Fe}, 23 \mathrm{wt} \% \mathrm{Ni}, 0.2 \mathrm{wt} \% \mathrm{Co}$ (probably taenite)

v0 wt\% Fe, 26 wt\% Ni, 0.5 wt\% Co, 14 wt\% P (schreibersite)

We have also examined sections of the Henbury (Figure 4.7) and Carbo (Figure 4.8) meteorites, which do not show evidence of residual fusion crust or $\alpha_{2}$ zones. The oxide on the Henbury surface we examined has a maximum thickness of $20.065 \mathrm{~mm}$. A localized oxide finger extends $0.162 \mathrm{~mm}$ into the metal. Other wel1-preserved Henbury specimens exist, including the one shown in Figure 4.4 .

Our examination of a Carbo specimen also indicated a relatively thin $(0.037 \mathrm{~mm})$ terrestrial oxide, with no evidence of fusion crust and $\alpha_{2}$ zones, as indicated in the preceeding section. Some oxide intrusion has occurred along cracks in the metal. The Carbo terrestrial age is estimated at up to 130,000 years (Ref. 1, p. 426).

Stage 4 - Advanced Weathering but with Observable Metal

The Ider meteorite (Figure 4.9) exemplifies this category. Radiocounting estimates place the age of this meteorite at $\sim 10^{6}$ years. ${ }^{(3)}$ The meteorite has undergone major oxidation, but substantial metal remains. 


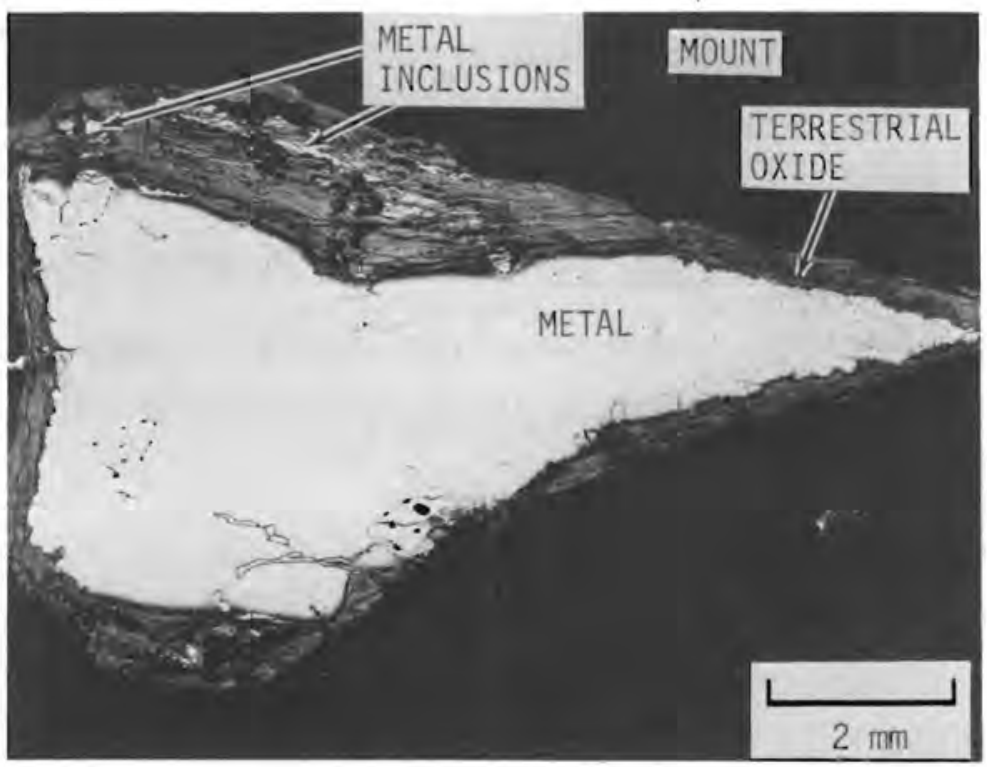

a. As-polished, Neg. No. 4P1068C, Mag. 6.3X

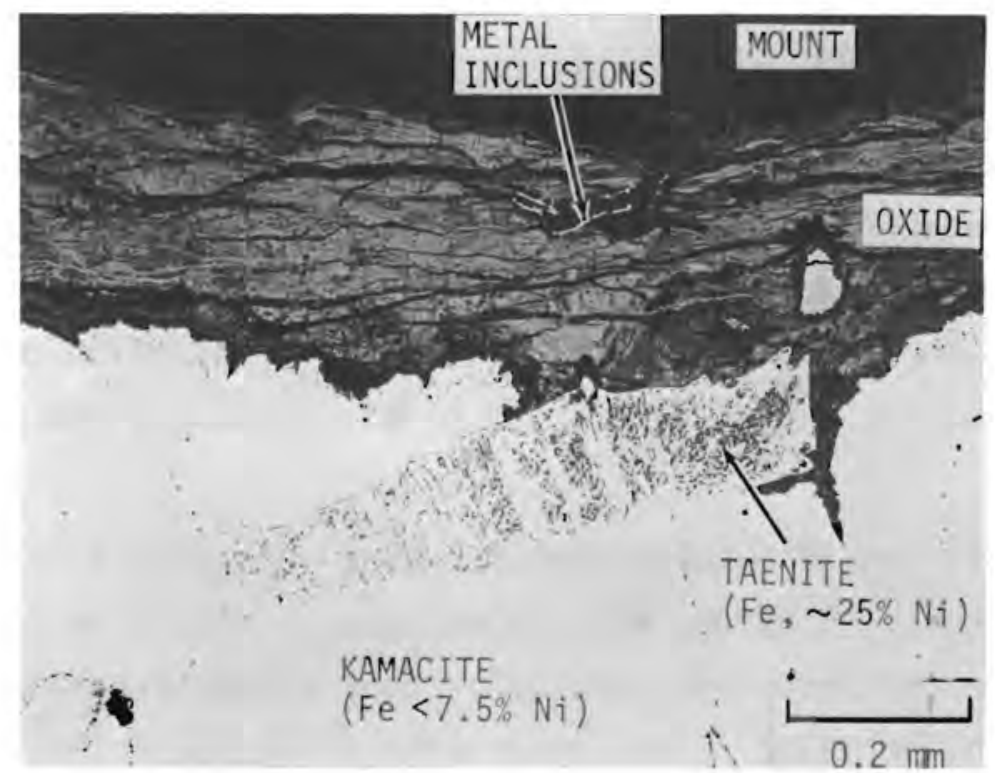

b. As-polished, Neg. No. 4P1068D, Mag. 50X

FIGURE 4.6. Metallographic Sections of Canyon Diablo Meteorite, Fell in Arizona, USA, Known to Indians for Centuries; Estimated Age: 20,000(1) Years, First Modern Cognizance, 1891 ; Section Supplied by E. 01sen, Field Museum, Chicago; Metallography by R. Beauchamp, Battelle, PNL, July 1979. Composition: (1) 7.10\% Ni, $0.46 \%$ Co, $0.26 \% \mathrm{P}$, About $1.0 \%$ C, About $1.0 \% \mathrm{~s}, 80 \mathrm{ppm} \mathrm{Ga}, 320 \mathrm{ppm} \mathrm{Ge,} 1.9 \mathrm{ppm} \mathrm{Ir}$, Remainder Fe. 


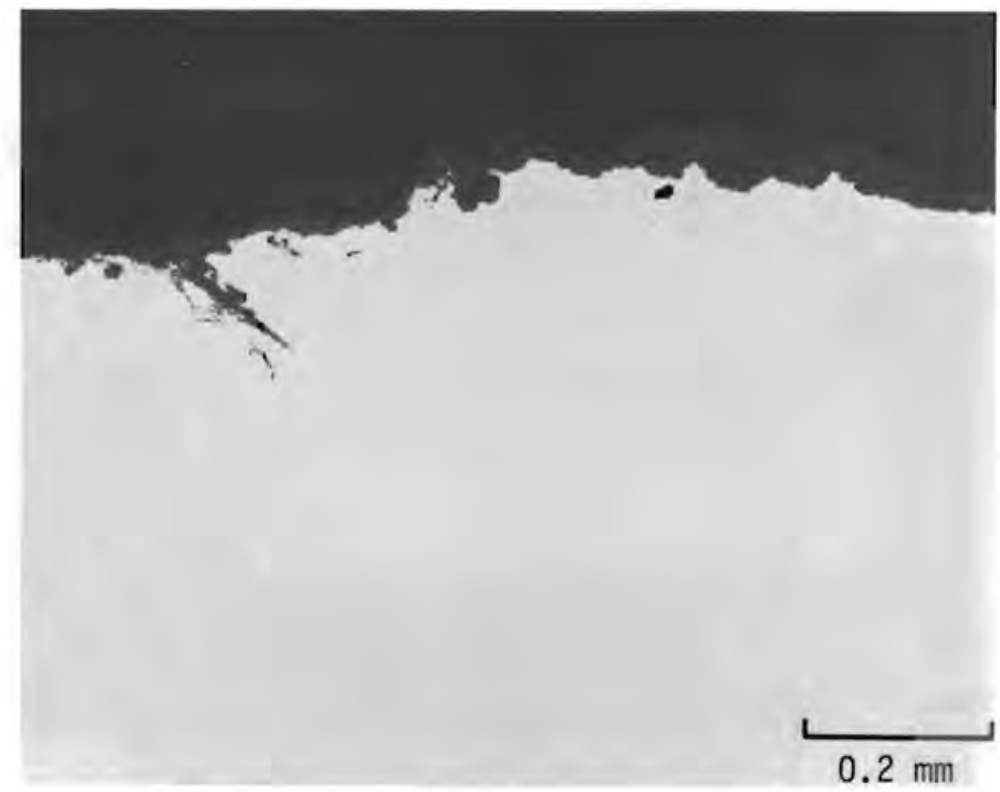

a. As-polished, Neg. No. 4P1069C, Mag. 100X

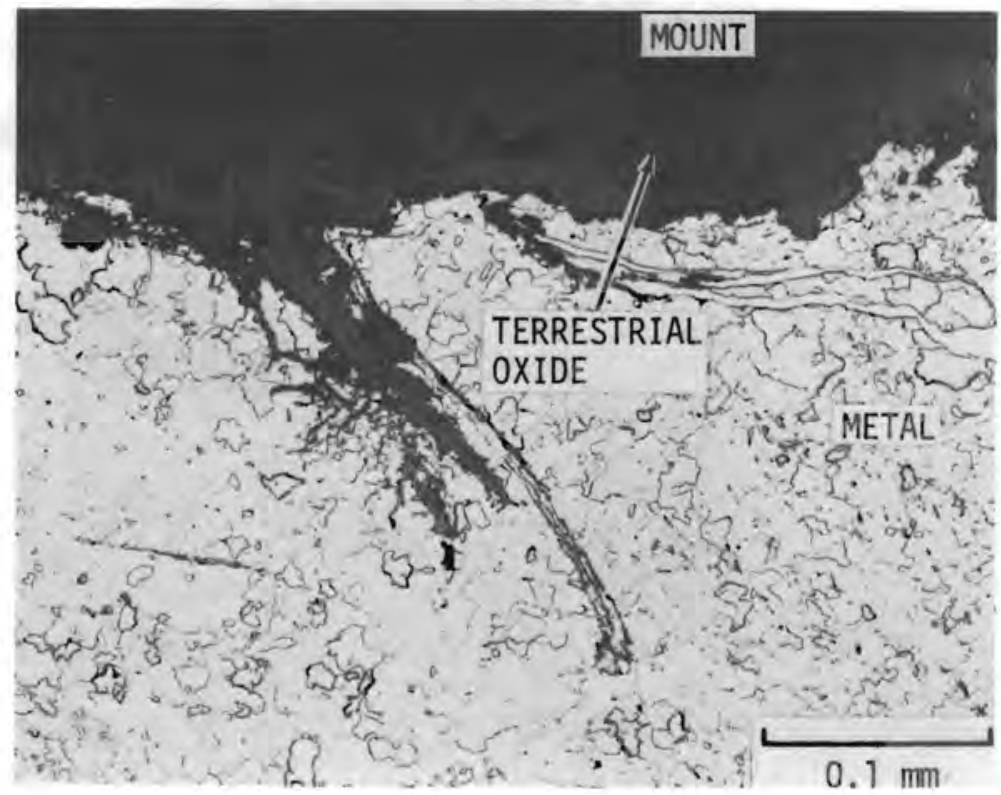

b. Etchant: 2\% Nita1, Neg. No. 4P1069I, Mag. 250X

FIGURE 4.7. Metallographic Sections of Henbury Meteorite, Fell in Northwest Territory, Australia, Discovered in 1931, Estimated Age: <5,000 Years. Section Supplied by E. 01sen, Field Museum, Chicago, Metallography by R. Beauchamp, Battelle, PNL, July 1979. Composition: (1) $7.51 \% \mathrm{Ni}, 0.45 \% \mathrm{Co}, 0.09 \% \mathrm{P}, 18 \mathrm{ppm} \mathrm{Ga}, 34 \mathrm{ppm} \mathrm{Ge}, 13$ ppm Ir, Remainder Fe. 


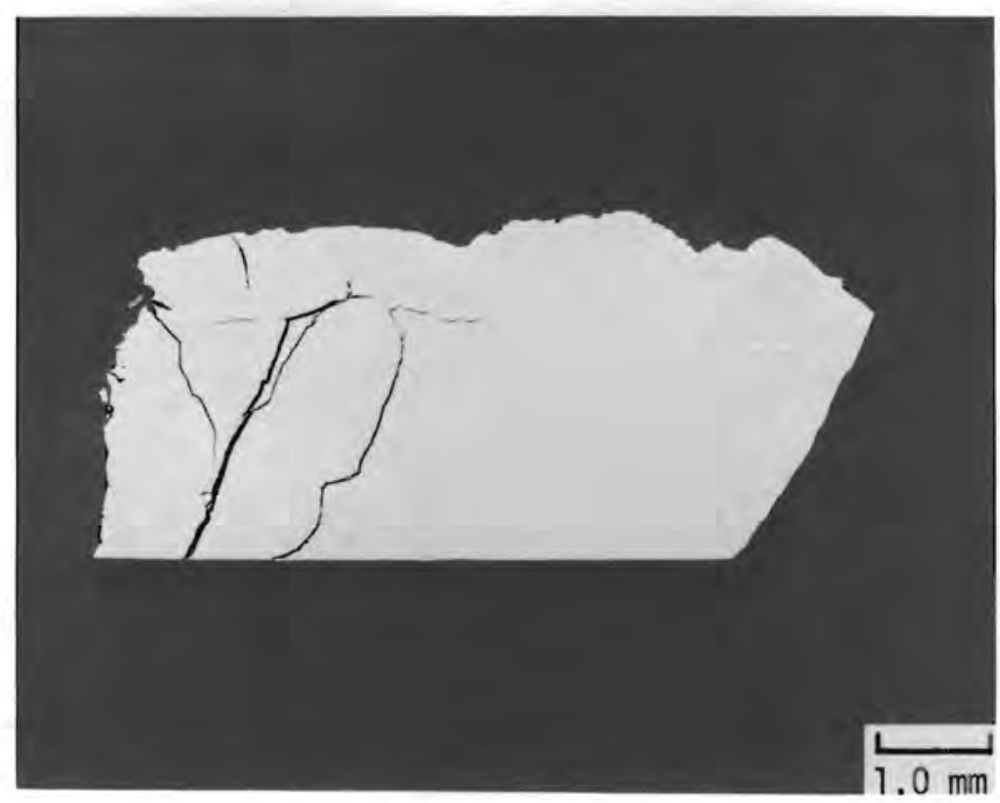

a. As-polished, Neg. No. 4P1067B, Mag. 12X

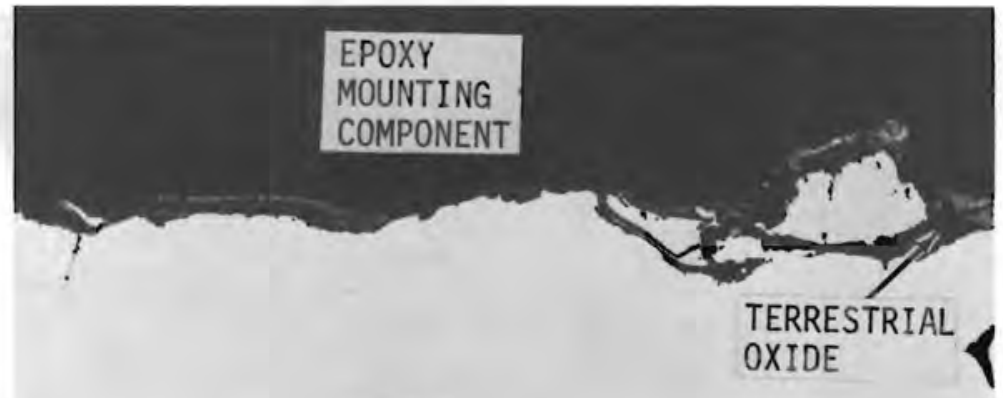

METAL

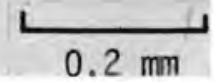

b. As-polished, Neg. No. 4P1067G, Mag. 100X

FIGURE 4.8. Metallographic Sections of Carbo Meteorite, Fell in Sonora, Mexico; Discovered in 1923, Estimated Age: $>100,000$ Years, Section Supplied by E. 01sen, Field Museum, Chicago; Metallography by R. Beauchamp, Battelle, PNL, July 1979. Composition:(1) 10.15\% $\mathrm{Ni}, 0.62 \% \mathrm{Co}$, About $0.5 \% \mathrm{P}, 70 \mathrm{ppm} \mathrm{Ga,} 87 \mathrm{ppm} \mathrm{Ge}$, $13 \mathrm{ppm}$ Ir, Remainder Fe. 


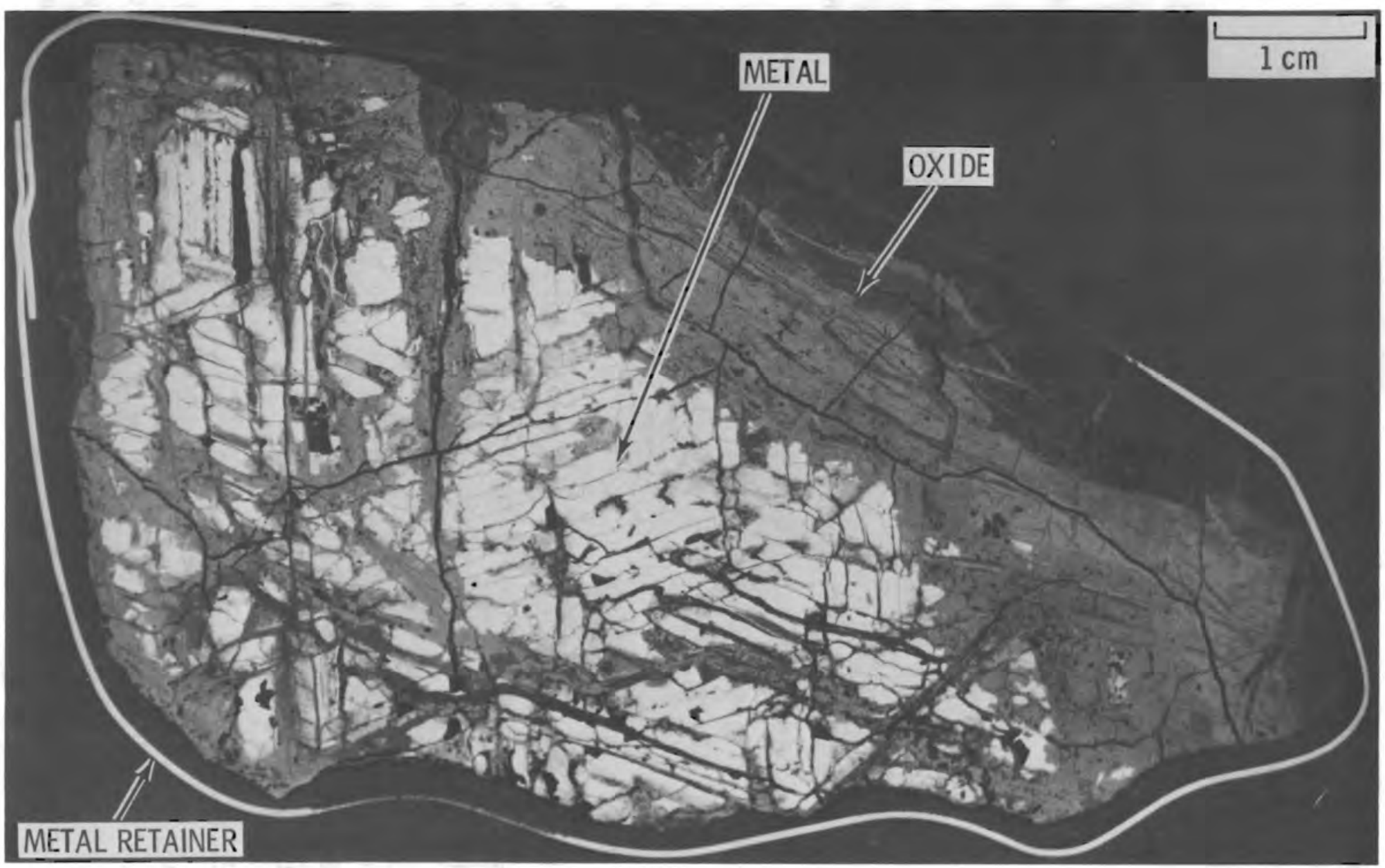

FIGURE 4.9. Ider Meteorite, Showing Advanced Weathering, But With Considerable Retained Metal. The Meteorite Was Found in Alabama, USA, in 1959. Radiocounting Suggests a Terrestrial Age Exceeding One Million Years. Composition: (1) $8.2 \% \mathrm{Ni}, 0.2 \% \mathrm{P}, 20 \mathrm{ppm} \mathrm{Ga}, 40 \mathrm{ppm}$ Ge. Photo Courtesy of Smithsonian Institution 
Shale balls are oxidized masses of metal meteorites buried in the soil. The shale balls generally are proximate to meteor craters, e.g., Boxhole, Canyon Diabalo, Henbury and Wolf Creek. $(1,5)$ Some shale balls weigh up to $220 \mathrm{~kg} .{ }^{(3)}$ Some have metal cores, which place them in Stage 4 weathering.

\section{Stage 5 - Fully Oxidized}

Some shale balls are fully oxidized at least on a macro scale. Fully oxidized shale balls have been observed near the Boxhole, Canyon Diablo, Henbury, and Monturaqui craters. ${ }^{(5)}$ In some cases, the meteorite oxide is very hard and coherent. In fact, some oxides cannot be cut with a hacksaw. (5)

White, et al.,(6) describe the advanced weathering of some Wolf Creek masses. Buchwald ${ }^{(1)}$ shows views of Wolf Creek fragments which are in Stage 4 weathering.

Several cases have been described where the meteorite mass appears to be fully oxidized. Close inspection indicates small metal inclusions in the oxide. The potential relevance of this observation to metal durability is discussed in the following section.

\subsection{FACTORS IN METEORITE DURABILITY}

On one hand, the metal meteorites have shown a substantial resistance to weathering: over half have retained features caused by heating in the earth's atmosphere, indicating that weathering has been minimal. On the other hand, some meteorites have specimens in a broad range of weathering conditions at a single site. Explanations for the range of weathering will be referenced largely to the Canyon Diablo site because weathering spans four stages and is described by substantial documentation. $(1,5)$

\subsubsection{Effect of Fusion Crusts}

Estimates of the total Canyon Diablo meteorite mass vary widely, but the estimated mass of collected and recognizable meteoritic material in the crater vicinity is 28,000 tonnes. More than 20,000 individual masses have been found, varying from $50 \mathrm{~g}$ to $639 \mathrm{~kg}$. Some fragmentation occurred in the earth's atmosphere, some occurred upon impact. 
The fusion crust which forms by high-temperature oxidation is a combination of magnetite $\left(\mathrm{Fe}_{3} \mathrm{O}_{4}\right)$ and wustite $\left(\mathrm{Fe}_{1-x^{0}} \mathrm{O}\right)$. Fused metal sometimes is incorporated into the oxides during ablation.

The prospect that undamaged fusion crust is protective seems plausible. Many meteorites displayed in museums have dark surface oxides which appear to be compact and coherent. Buddhue acknowledges its probable protective nature. Black, compact magnetites often are intentionally formed on ferrous alloy components to provide protection from corrosion (Ref. 7, p. 248). However, local damage may occur to the fusion crust upon impact, resulting in a localized surface region which is corrosion-prone.

On the hypothesis that the fusion crust is protective, its value accrues principally to surfaces of fragments formed on the descent through the atmosphere. Fragments formed on impact or even late in the descent may have little or no fusion crust. While still speculative, the presence or absence of a fusion crust may be a major factor in the range of weathering which occurs at sites where meteorites fragment both on descent and upon impact.

As further evidence for this view, Buchwald (Ref. 1, p. 391) identifies seven degrees (stages) of altered metal for Canyon Diablo specimens, depending on the combined effects of shock and heat. The seven stages range from no visible metallurgical alteration (Stage I) to alteration corresponding to shock-melted material (Stage VII) estimated to have attained temperatures above $1,050^{\circ} \mathrm{C}$.

Buchwald's descriptions suggest that the larger Canyon Diablo masses (up to $640 \mathrm{~kg}$ ) appeared to have separated from the incoming mass at an early stage. They are described as lightly shocked and almost unaltered. They have normal $2 \mathrm{~mm}$ thick $\alpha_{2}$ layers, where less than $0.5 \mathrm{~mm}$ has been lost to weathering. Regmaglypts also are evident.

Stages II through VII appear to have been formed upon impact. The Stage II (shock-hardened) masses (usually 50 to $1,000 \mathrm{~g}$ ) have varying metallurgies within the same mass. The presence or absence of fusion crusts is not mentioned, but they probably were absent or very thin. The Stage III (shockannealed) material is covered with "limonitic crusts and probably never had 
fusion crusts and head-affected zones of the usual kind." The Stage IV through Stage VII material also appears to have come from fragments formed during the impact.

There is a stage beyond VII which involves small metal particles or spherules. There is evidence that the spherules were coated with a thin silica coating immediately after formation during impact. The coating appears to account for resistance of the spherules to weathering over the many millenia since their formation.

In summary, there is a strong suggestion that Canyon Diablo material which developed a fusion crust during the descent was more resistant to weathering than masses formed on impact, which developed little or no fusion crust. The exception was the metal spherules, which formed upon impact, but resisted weathering by virtue of the silica layer which coated the metal particles.

\subsubsection{Effect of Burial or Partial Burial in Soil}

Buchwald indicates that on some Canyon Diablo masses partially buried in the desert soil, corrosion was accelerated below the soil line. Above the soil line weathering was minimal. Similar observations are reported for other partially buried meteorites: Bendego, Boxhole, Cape York, Drum Mountain, Oakley, Quinn Canyon, Gibeon, Henbury, Rateldraai, Santa Luzia, Zerhamra. These meteorites show a consistent pattern of more severe corrosion on the portion of the metal which was below the soil line. This is also true of Mundrabilla, on display at the Smithsonian (Figure 4.10). The bottom side, buried in the soil, has intermittent layers of relatively thick terrestrial corrosion product (see arrows). The surface, exposed to the atmosphere, is free of the thick oxides and has some residual $\alpha_{2}$ zone on the left-hand side.

Acceleration of corrosion on buried sections of meteorites appears to provide an explanation for Stage 4 and 5 weathering on shale balls at Canyon Diablo and other crater-forming meteorites. Buchwald (Ref. 4.1, p. 398) indicates that a few Canyon Diablo shale balls were found on the surface, but 


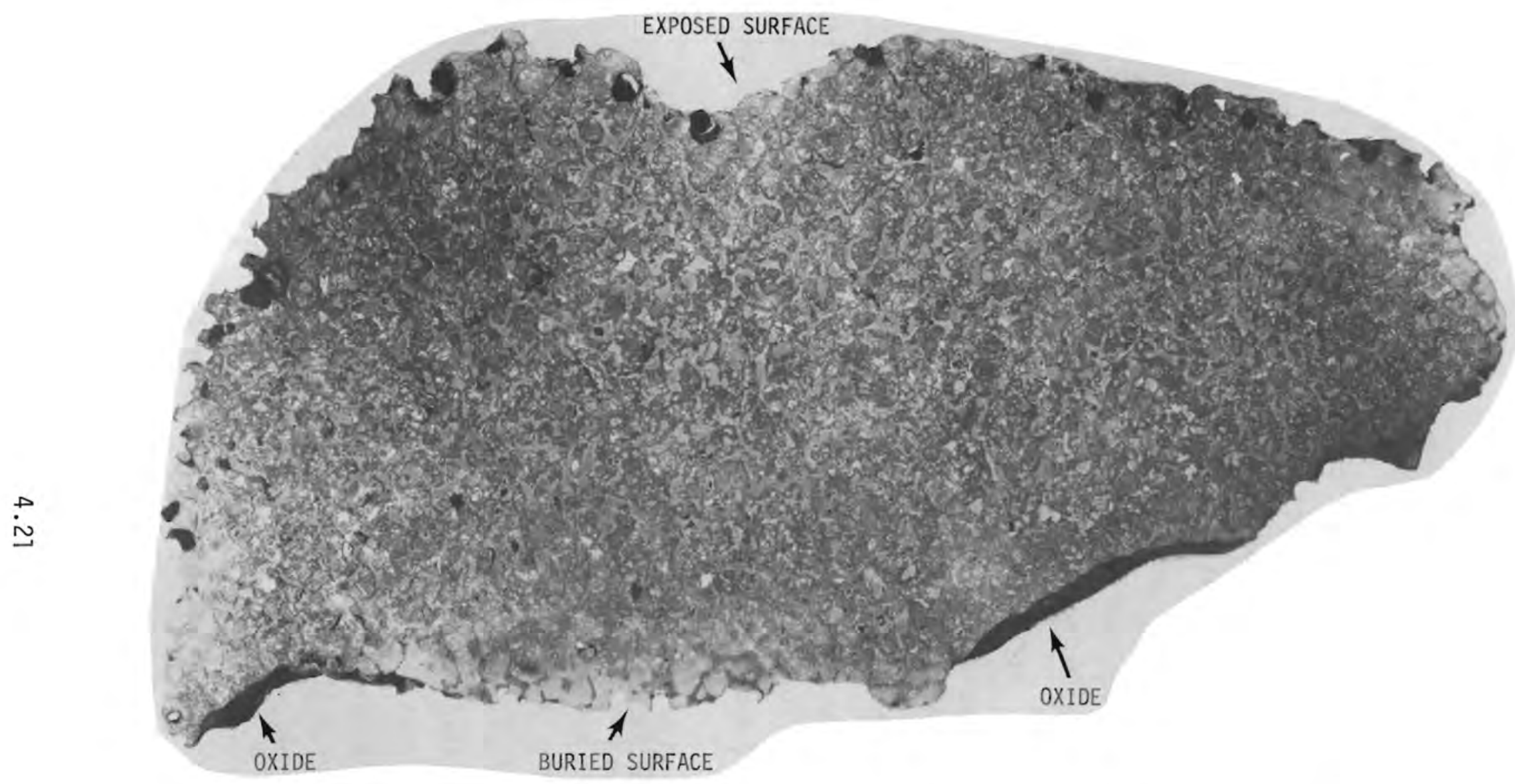

FIGURE 4.10. Slab of Mundrabilla (Octrahedrite) on Display at the Smithsonian Institution, Washington, DC. The Meteorite Was Found on the Arid Nullarbor Plain, Western Australia. Composition:(1) $7.8 \% \mathrm{Ni}, 0.26 \% \mathrm{P}, 1 \% \mathrm{C}, 8 \% \mathrm{~S}$. Photograph Courtesy of the Smithsonian Institution. Note Thick Terrestrial Corrosion Layers on Lower Surface. Some $\alpha_{2}$ Zone Remains on Left-Hand Surface. Total Length is $154 \mathrm{~cm}$ (54 in.) 
most are buried. (a) Buchwald attributes the advanced weathering to subsurface corrosion.

\subsubsection{Effect of Contaminants}

Buddhue $^{(5)}$ reflects an early view of meteoriticists that lawrencite $\left(\mathrm{FeCl}_{2}\right)$ is a cosmic mineral transported to earth on selected meteorites. Buddhue specifically mentions evidence for lawrencite on Brenham, Cranbourne, Lick Creek, Monahans, Paulding County, Sardis, and Summit. However, the existence of lawrencite as a cosmic material has never been proved.

In the case of Cranbourne, chlorides were cited as a major factor in rapid degradation when a large mass was moved from the relatively dry site where it fell (Victoria, Australia) to the moist London atmosphere at the British museum.

Buchwald (Ref. 1, p. 398) discounts lawrencite as a cosmic material and attributes chloride accumulation on meteorites to ground water impurities. Buchwald (Ref. 1, p. 383) indicates that some corroded Canyon Diablo specimens were rich in chlorine and sulfur.

The predominant view now is that chlorides on metal meteorites are of terrestrial origin, except for traces of cosmic origin. (b) Chlorides and sulfur, of terrestrial origin, appear to be significant sources of accelerated corrosion on some meteorites.

\subsubsection{Effect of Metallurgical Factors}

Buddhue (Ref. 5, Plate I) shows evidence for preferential corrosion intrusions along shock-induced Neumann bands.

Buchwald notes (Ref. 1, p. 658) that metal knives, chisels, etc. were fashioned from meteoritic materials by the Hopewell Mound builders in Ohio. Their culture is dated to $\sim 500 \mathrm{BC}$ to $500 \mathrm{AD}$. The meteoritic artifacts were less durable than ornaments or implements made from gold, silver or copper. Nearly all the ferrous artifacts were severely oxidized, although the more massive unworked meteorite fragments have survived with only superficial

(a) The few exceptions may represent shale balls removed by early human visitors to the crater.

(b) Chlorine contents measured in many meteorites are generally in the range of 1 to $10 \mathrm{ppm}$ (Buchwald, Vol. 1, p. 82). 
limonitic crusts and some grain boundary corrosion. The metal working, contamination from human handling or storage environments or a combination of factors probably account for the lower weathering resistance of the meteoritic artifacts. Archaeological artifacts of apparent meteoritic origin, found at Ur (from 3000 BC) and in burial mounds near Havanna, Illinois also had substantial oxidation.

Some mineral phases in the meteorites appear as inclusions in the terrestrial oxides, including schreibersite, rhabdite, taenite, cohenite and unmelted, undamaged troilite. We have already indicated an example of such phases in the oxide of a Canyon Diablo specimen (Figure 4.4).

Protection can occur by anodic/cathodic couples between two mineral phases. However, cases are cited (e.g., Ref. 5) where the metallic inclusions persist in meteoritic oxides with no residual metal core, suggesting inherent resistance to oxidation.

There is substantial evidence that taenite (e.g., Ref. 5, Plate II) and schreibersite (Ref. 5) resist corrosion over millenia in meteoritic oxides. Buchwald notes other cases (his Figures 713, 2043 and 1444).

\subsubsection{Environmental Factors}

The climate at the Canyon Diablo crater currently is dry. Buddhue (Ref. 5, p. 105) indicates total annual moisture of 8 to 9 inches (20 to 23 $\mathrm{cm})$. However, there is evidence that a lake once formed in the crater, during the last Pleistocene ice age (probably 10,000 to 15,000 years ago). Thus, the Canyon Diablo meteorite masses have been exposed to considerably more moist conditions than those which now exist. The moist period probably extended over several millenia. Metal masses on the surface of the soil apparently survived the moisture quite well (Section 4.3.1), but degradation of buried metal masses may have been accelerated by the increased ground water.

The Canyon Diablo site is prone to annual freeze-thaw cycles which also tend to promote accelerated corrosion once porous oxides began to form.

We mentioned earlier the case of the Cranbourne meteorite which survived much better where it fell in dry Victoria, Australia than in moist Loindon. 


\subsubsection{Effect of Nickel Content}

Phases of 20 to $30 \mathrm{wt} \%$ nickel have frequently shown superior resistance to terrestrial corrosion, as indicated previously. Seven meteorites have nickel contents in the range 25.6 to $260 \mathrm{wt} \%$. Weathering data are unreported $(1)$ for the two highest nickel contents. The remaining high-nickel meteorites have not been singularly and impressively resistant to weathering. However, the terrestrial ages are unknown, so there is no basis for comparison with the weathering resistance of meteorites with lower nickel contents.

A study of atmospheric corrosion of stainless steels and nickel alloys over a 10-year period indicated marked dependence of corrosion on metal composition. (8) The exposures were made at a semi-industrial site in Birmingham, England.

Steels with $13 \%$ chromium, with or without nickel (Types $430,431,410$, and 13- $\mathrm{Cr} 12-\mathrm{Ni}$ ) quickly developed thick rust, covering 90 to $100 \%$ of the surface area. Type $302(18 \mathrm{Cr}-8 \mathrm{Ni}$ ) had a thinner rust layer, confined to 45 to $55 \%$ of the surface area. Type 321 steel (Ti-stabilized 18/8) was inferior to Type 302: the rust covered 75 to $80 \%$ of the surface and was thicker. The presence of TiC particles may have served as nuclei for rust and pits.

Four austenitic $\mathrm{Cr}-\mathrm{Ni}$ steels containing molybdenum remained rust-free throughout the 10-year test. The alloys were: Type $316,18 \mathrm{Cr}-10, \mathrm{Ni}-1.3 \mathrm{Mo}$, Type $316 \mathrm{Ti}$, and $18 \mathrm{Cr}-18 \mathrm{Ni}-4 \mathrm{Mo}-3 \mathrm{Cu}$. Type $310(25 \mathrm{Cr}-20 \mathrm{Ni}$ ) also remained free of rust, though it did not contain Mo, probably due to increased $\mathrm{Cr}$ and $\mathrm{Ni}$. Of several nickel alloys tested, the nickel-chromium-iron materials Alloy 600 and Alloy DS were the most resistant to atmospheric corrosion.

Buchwald (e.g., Vol. I, Figure 93 and Vol. III, Figure 1874) notes that the duplex of $\alpha-\gamma$ structure disintegrates by selective 


\subsection{REFERENCES}

1. V. F. Buchwald. Handbook of Iron Meteorites. University of California Press, Berkeley, California, 1975 in three volumes.

2. C. Chang and H. Wänke. "Beryllium-10 in Iron Meteorites, Their Cosmic Ray and Terrestrial Ages." Meteorite Research. P. Millman, ed., Riddel, 1969.

3. B. Mason. Meteorites. Wiley and Sons, New York, 1962.

4. E. J. 01 sen, A. Noonan, K. Fredriksson, E. Jarosewich, G. Moreland. "Eleven Meteorites from Antarctica." Meteoritics. 13:209 (1978).

5. J. D. Buddhue. The Oxidation and Weathering of Meteorites. University of New Mexico Publications in Meteoritics, No. 3, Albuquerque, NM, 1957.

6. J. S. White, Jr., E. P. Henderson and B. Mason. "Secondary Minerals Produced by Weathering of the Wolf Creek Meteorite." The Am. Mineralogist. $52: 1190-1196,1967$.

7. H. H. Uhlig. Corrosion and Corrosion Control. Wiley and Sons, Inc.

8. T. E. Evans. "Atmospheric Corrosion Behavior of Stainless Steels and Nickel Alloys." Proceedings of the Fourth International Congress on Metallic Corrosion, Amsterdam, 1969, available from the National Association of Corrosion Engineers, Katy, TX. 


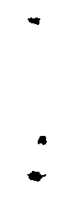

$\checkmark$

'

.

:

เ 


\subsection{NATIVE METALS}




\subsection{NATIVE METALS}

Native metals are ores which occur in nature in the metallic state. The most common native metals are copper, gold, and silver, but arsenic, antimony, bismuth, iron, iron-nickel alloys, mercury, platinum, and in very small amounts, lead, palladium, tantalum, and tin ${ }^{(1)}$ also occur in nature as metals. We have previously alluded to man's early use of native copper, gold, silver, and platinum (Section 2.0).

The geologic age of the native metals is almost always uncertain. Often they are associated with rock formations having ages of many million years on the geologic time scale. The native metals sometimes are thought to be syngenetic or contemporary with the surrounding rock. In other cases, they are epigenetic, i.e., younger than the surrounding rock.

In some cases, the native metals have been transported from the formation where they were first deposited. Native gold and several other metals are found in stream beds and placer deposits. Native copper boulders from deposits in Upper Michigan were transported by the Pleistocene glaciers as far south as what are now Illinois and Indiana. $(2,3)$

In general, the time span of weathering for the native metals also is uncertain. The weathering time for native copper, gold, silver, and platinum extends over at least several thousand years, evidenced by human utilization. Geologic action, such as glacial transport of copper, places a lower bound on the weathering time (see Section 5.5). Thus, weathering of the native metals over 5,000 to 10,000 years is essentially certain. The upper bound is unclear, but often the geologic evidence suggests much longer weathering times.

\subsection{NATIVE GOLD, SILVER, PLATINUM, AND PALLADIUM}

Native gold is among the first metals utilized by man, due to its easy recognition and relatively wide distribution. Native gold is the most common gold ore.

Native silver often is associated with and alloyed with gold. However, the sulfide (argentite) is the most common commercial source of silver. 
Native silver has been utilized by humans over several millenia (Section 2.0). Silver alloyed with gold in amounts exceeding $20 \mathrm{wt} \% \mathrm{Ag}$ is called electrum.

Tylecote ${ }^{(4)}$ mentions evidence that platinum was used in early metal working, but it was a minor factor. Native platinum is often associated with gold and silver. Native platinum contains 60 to $85 \%$ platinum. The form is generally as small grains, but a mass weighing $210 \mathrm{~kg}$ was found in Russia in 1843. (5) Native palladium has been reported, but in minor amounts compared to platinum.

\subsection{MERCURY}

Evidence is cited that ancient Chinese used mercury. ${ }^{(6)}$ There also is evidence for use of mercury in artifacts from Egyptian tombs dating to 21500 $B C{ }^{(5)}$ Whether it came from non-metallic mercury ores (e.g., the sulfide, cinnibar) or from the liquid native metal is not clear.

\subsection{NATIVE IRON AND IRON-NICKEL ALLOYS}

Native iron occurs only rarely. Small amounts have been reported in Ireland, France, Poland, U.S.S.R., and in Missouri and New Jersey in the U.S. (1) The most important native iron deposits occur on Disko Island, Greenland. The iron is associated with basalt deposits, in forms from small particles to masses weighing up to 20 tonnes.

The Field Museum in Chicago has a native iron specimen from Greenland. The specimen has a rusted exterior, but appears to be largely metallic. The weathering time is not clear.

Native nickel-iron alloys have occurred in small amounts as placer deposits in New Zealand, U.S.S.R., and Canada. Some masses up to $250 \mathrm{~kg}$ have been found in Oregon. (7) Native iron is alloyed with 2 to $7 \%$ nickel. The nickel-iron alloys vary from 30 to $75 \%$ nickel. There is evidence that early man made implements from native iron and nickel-iron alloys. (1) Use of meteoritic iron was indicated in Section 2.

The iron sulphides (particularly pyrite, $\mathrm{FeS}_{2}$, or fool's gold), while nonmetallic and probably quite brittle, are very durable and maintain a bright metallic sheen over what must have been several millenia of exposure to weathering in some environments. 


\subsection{ARSENIC, ANTIMONY, AND BISMUTH}

Metallic arsenic and antimony generally occur in the same locations. Native bismuth sometimes occurs with nickel and cobalt ores. Native zinc has been reported but is not well confirmed.

Metallic antimony has been reported in archaeological forms. ${ }^{(8)}$ Arsenical copper is a well known archaeological material, but was more likely derived from non-metallic rather than metallic ores.

\subsection{RARE NATIVE METALS $(1)$}

Native tin is very rare. Some small grains occur in sands in New South Wales, Australia. Native lead also is rare; some large crystals occurred in Sweden. Native tantalum has been reported in very small amounts in placer deposits in the U.S.S.R.

\subsection{NATIVE COPPER}

Native copper has been the most important natural metal, from the standpoint of early engineering applications such as weaponry and tool fabrication. Native copper was among the first metals used by man. Copper artifacts dating to $6000 \mathrm{BC}$ (Table 2.4) almost certainly were fashioned from native copper. Hammering and annealing of copper into useful shapes also produced mechanical properties which were attractive for weapons and implements, in contrast to less useful properties of gold and silver. Early copper artifacts have been excavated at several sites in modern-day Iran, Iraq, Turkey, Syria, Jordan, Saudi Arabia, Palestine, Egypt, and Cyprus. Numerous ancient copper artifacts also have been found in the Western Hemisphere, ${ }^{(2)}$ dating to as early as $3000 \mathrm{BC}$.

Copper smelting apparently began much later than the first use of native copper. By $3100 \mathrm{BC}$, copper melting and casting had begun in Ur. There is evidence that copper casting was practiced by the Aztecs, though much later than in the Eastern Hemisphere.

Native copper deposits occurred in Asia Minor, England, France, Russia, Hungary, and Cyprus in the 0ld World. In the Western Hemisphere, native copper was found in Bolivia, Canada, Southwestern U.S and Appalachia; however, the world's largest deposits occurred in Northern Michigan. 


\subsection{MICHIGAN NATIVE COPPER DEPOSITS}

The Michigan native copper lies in a band 2100 miles $(167 \mathrm{~km})$ long and 2 to 4 miles ( 3.7 to $6.5 \mathrm{~km}$ ) wide on the Keweenaw Peninsula (Figure 5.1). Similar deposits also were discovered on Isle Royale. The deposits are of three types: 1) lode deposits (conglomerate); 2) lode deposits of an amygdaloidal(a) type, associated with lava intrusions; 3 ) fissure deposits. The conglomerate and amygdaloidal deposits were the most important commercially.

Through 1971, approximately 5,000,000 tonnes of native copper were extracted from the Michigan deposits. The native metal had a very low impurity content (up to $99.998 \mathrm{wt} \% \mathrm{Cu}$ ). Some of the deposits have metallic silver inclusions. (2) Commercial working of the copper deposits began 21840 , rose to a maximum production of 2100,000 tonnes per year in 1910, then declined to minimal activity in the 1960s.

\section{KEWEENAW PENNINSULA}

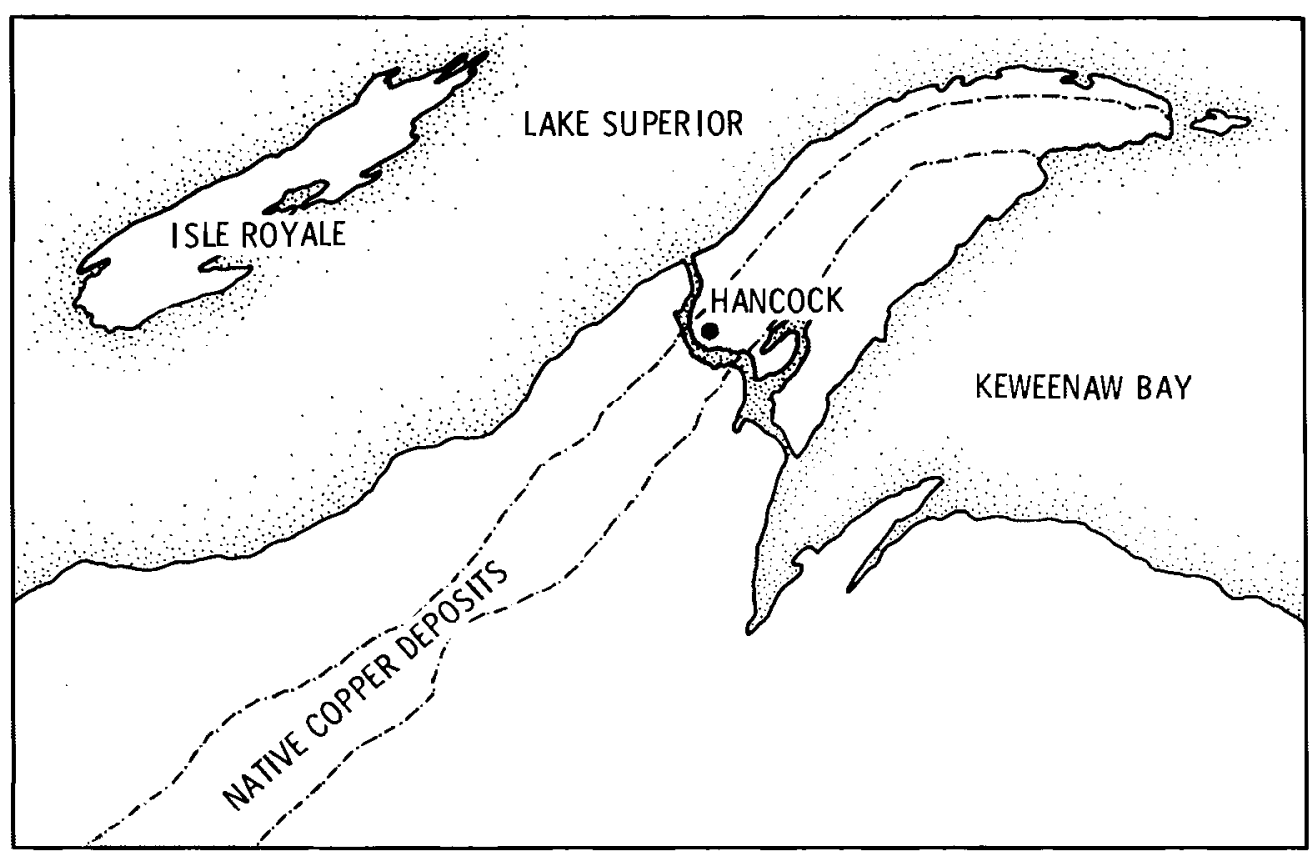

FIGURE 5.1. Location of Michigan Native Copper Deposits

(a) Amygdaloid is an igneous rock containing cavities. The cavities are filled with mineral deposits, as in the case of the native copper. 
There is extensive evidence that early native Americans worked the Michigan copper deposits. Approximately 5,000 sites have been identified, where the metallic copper was extracted by primitive means: alternate thermal shocks on the surrounding rock by fires and dousing with water, followed by beating off clumps of the exposed copper with stone hammers. (2) Carbon dating suggests that the copper deposits were worked up to 3,500 to 4,000 years ago.

Copper artifacts have been found at numerous North American and Central American locations (see Figure 5.2). The artifacts include knives, spear heads, wedges, axes, bracelets, fishhooks, etc., some dating to $23000 \mathrm{BC}$ (2) Metallic silver inclusions in some of the lichigan copper help to identify the source, though the incidence of silver inclusion appears to be infrequent. The inclusions also indicate that the artifacts were not fabricated at temperatures which would disperse the silver in the copper. However, much of the Michigan copper has only traces of silver.

\subsection{FLOAT COPPER}

Masses of native copper transported by glaciers are called "float copper." In addition to metallic copper localized in the ore deposits, the upper midwestern states are littered with numerous masses of metallic copper. Sizes range from small pebbles to large masses $(28,000 \mathrm{~kg})$. (a) The float copper appears to have been transported from the primary copper deposits in Upper Michigan by the Pleistocene glaciers. The glacial period extended from 2-1/2 million years ago to the most recent incursion which began $\sim 20,000$ years ago and receded 8,000 to 11,000 years ago. The glaciers extended across presentday Michigan, Wisconsin, and into a large fraction of I1linois and Indiana (see Figure 5.3). (3)

Much of the float copper in Michigan is found in glacial outwash; gravel banks which formed part of the moraine as the glaciers melted.

We have examined two pieces of the float copper which had evidence of glacial abrasion. Results are discussed in the following section.

(a) The Ontonagon copper boulder on display at the Smithsonian Institution weighs $\sim 1,400 \mathrm{~kg}$. It is an example of a large copper mass transported by the glaciers. (9) 


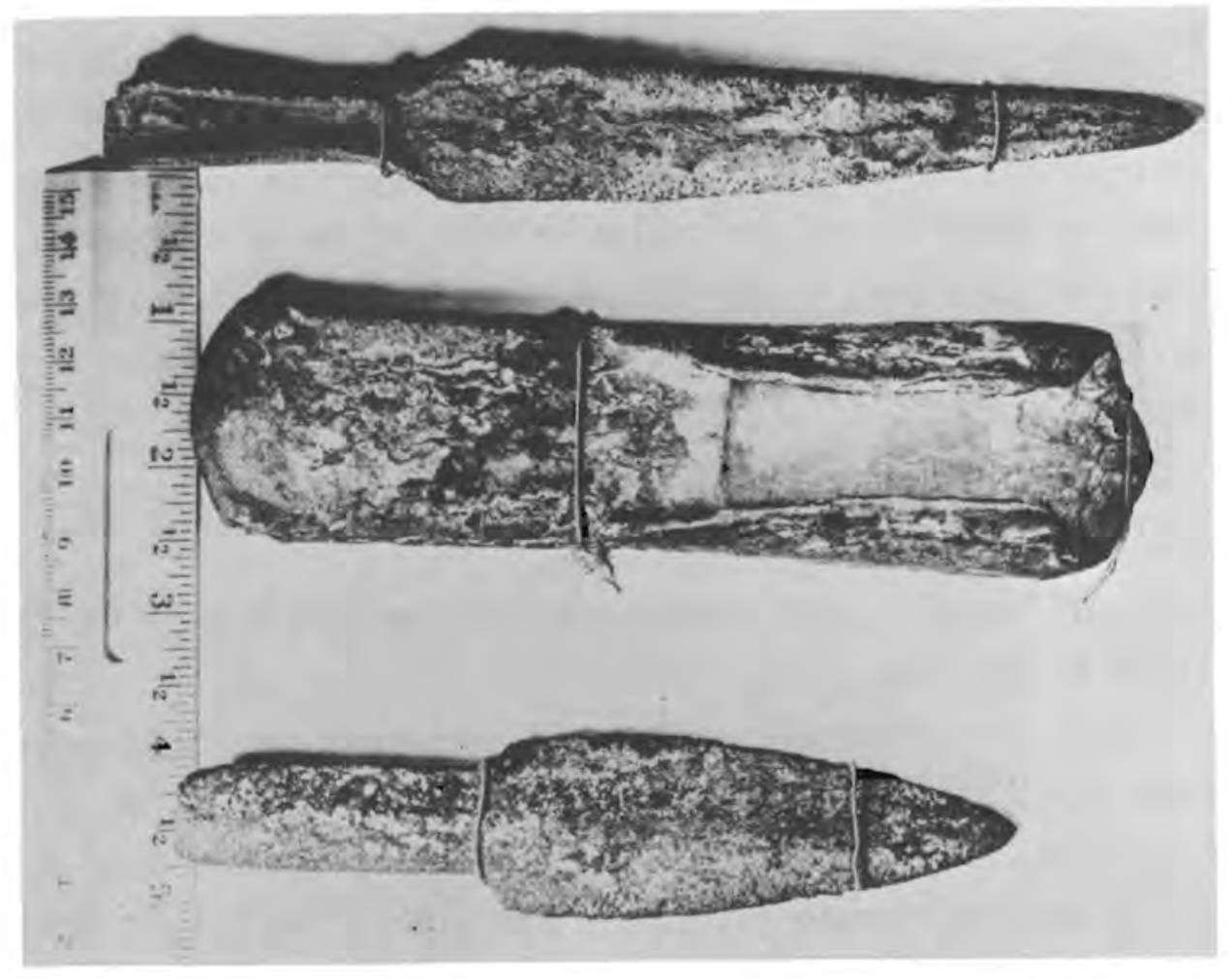

SOCKETED SPEAR POINTS - SOCKETED HOE OR AXE Approximately three-quarters size.

(Michigan College of Mining \& Technology collection).

FIGURE 5.2a. Artifacts Fashioned From Michigan Native Copper by Native Americans (From Ref. 2, p. 81) 


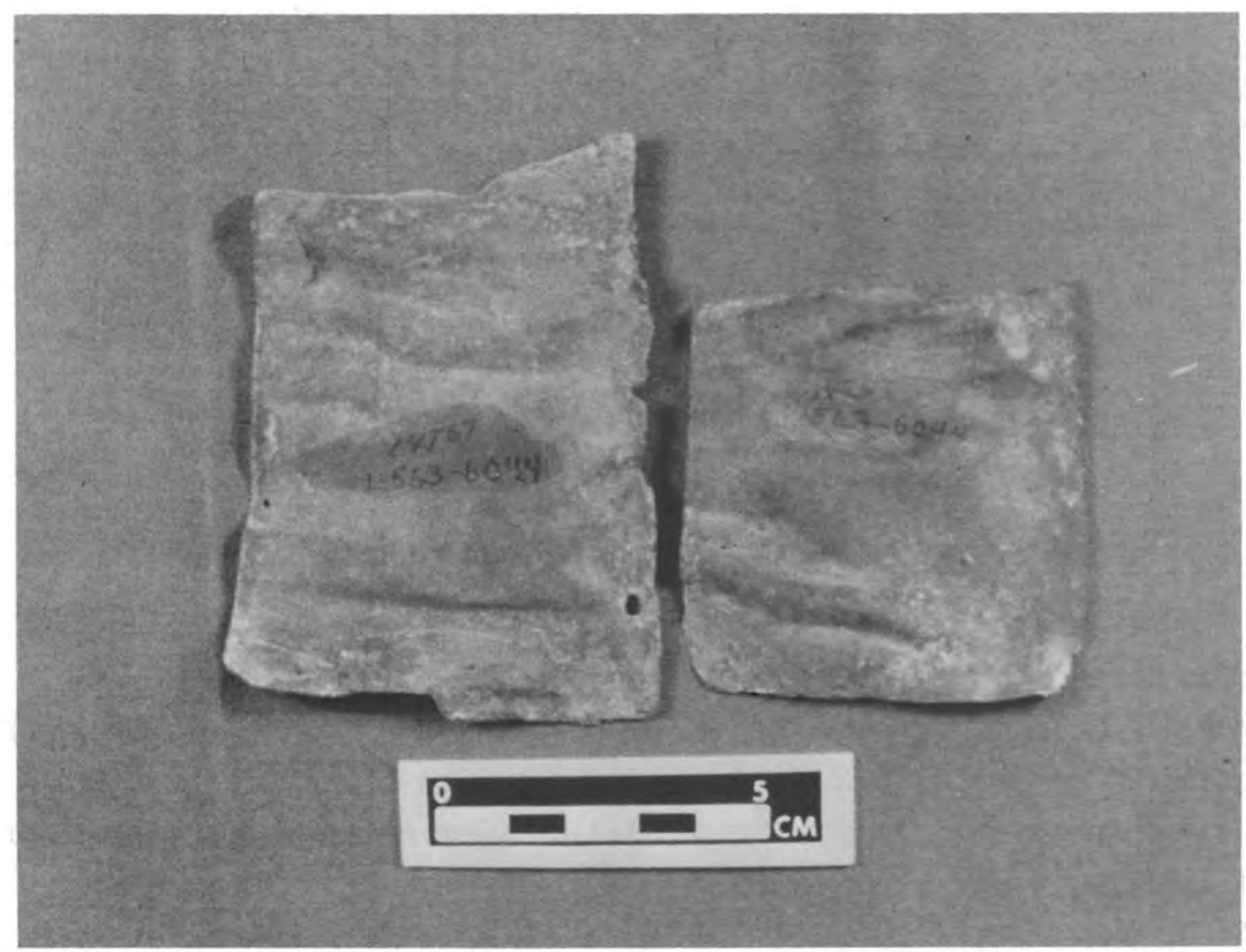

FIGURE 5.2b. Copper Breast-Plates From Hopewellian Period, 200 BC to 400 AD; Copper Thickness - About 1 mm; Very Little Corrosion; Found in West Virginia - Possibly From Appalachian Copper Outcrops; Photo Courtesy Emil Veakis, Brookhaven National Laboratory 


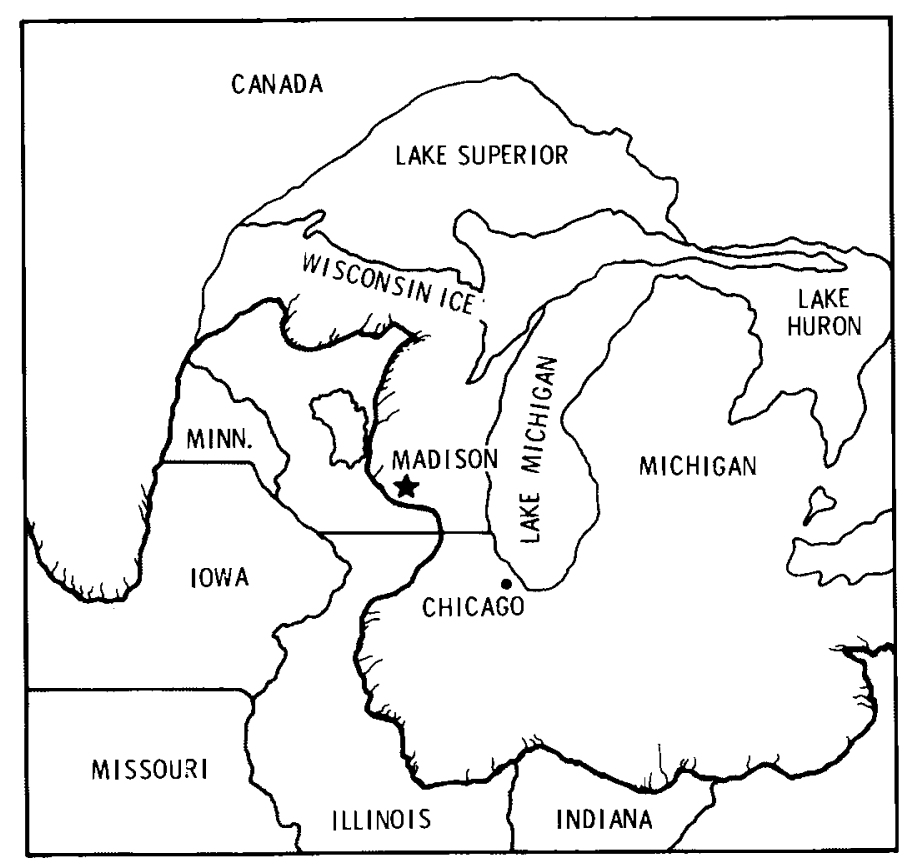

FIGURE 5.3. Maximum Penetration of Glaciers - Last (Fourth) Pleistocene Ice Incursion 8,000 to 20,000 Years Ago

\subsection{EXAMINATION OF WEATHERING ON FLOAT COPPER FROM THE MICHIGAN DEPOSITS}

Figure 5.4 shows front and back views of a $4 \mathrm{~kg}$ copper boulder. Striations in Views $A$ and $C$ appear to have glacial origin (Nos. 1 and 2). The boulder was found on the outskirts of Hancock, Michigan (see map, Figure 5.1). It was buried about $2 \mathrm{ft}(0.6 \mathrm{~m})$ deep in sand and gravel which is part of a glacial outwash. The last glaciers in that area are estimated to have melted about 8,000 years ago as indicated in discussions with Professors B. Hamill and S. Nordeng of the Michigan Technological University, Houghten, Michigan.

The area currently receives an average moisture fall of 30 to 50 in. (75 to $125 \mathrm{~cm}$ ). The copper would have gone through annual freeze-thaw cycles. The boulder almost certainly would have been washed annually by percolating waters from melting snows. The waters tend to be acidic, controlled mainly by equilibrium with atmospheric carbon dioxide ( $\mathrm{pH}$ 5.8). The current annual mean temperature in the area is $44^{\circ} \mathrm{F}\left(7^{\circ} \mathrm{C}\right)$. The maximum atmospheric temperature is $2100^{\circ} \mathrm{F}\left(38^{\circ} \mathrm{C}\right)$. 


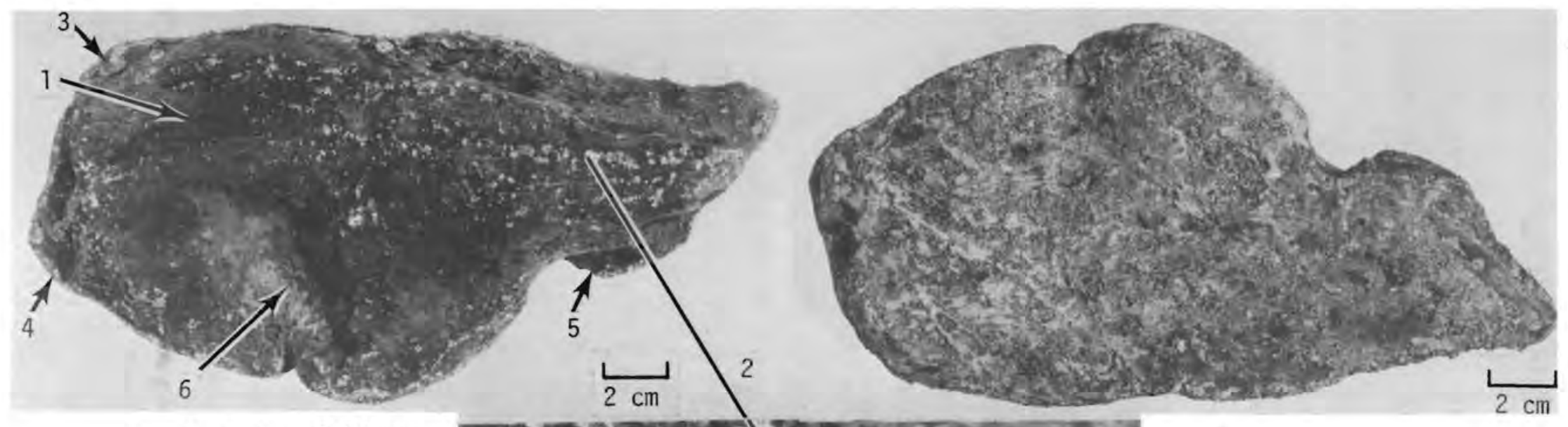

a. Neg. No. 4P1077W Top View 0.5X

G Note: Top surface is dark green; bottom surface is lighter green. Oxide is duplex: inner layer is cuprite ( $\left.\mathrm{Cu}_{2} \mathrm{O}\right)$; outer layer is malachite $\mathrm{Cu}_{2}(\mathrm{OH})_{2} \mathrm{CO}_{3}$. Arrows 1 and 2 indicate striations. Arrows 3, 4 and 5 indicate areas where tabs of metal were bent during glacial transport. Arrow 6 indicates a location where a quartz mineral appears to have been embedded in the

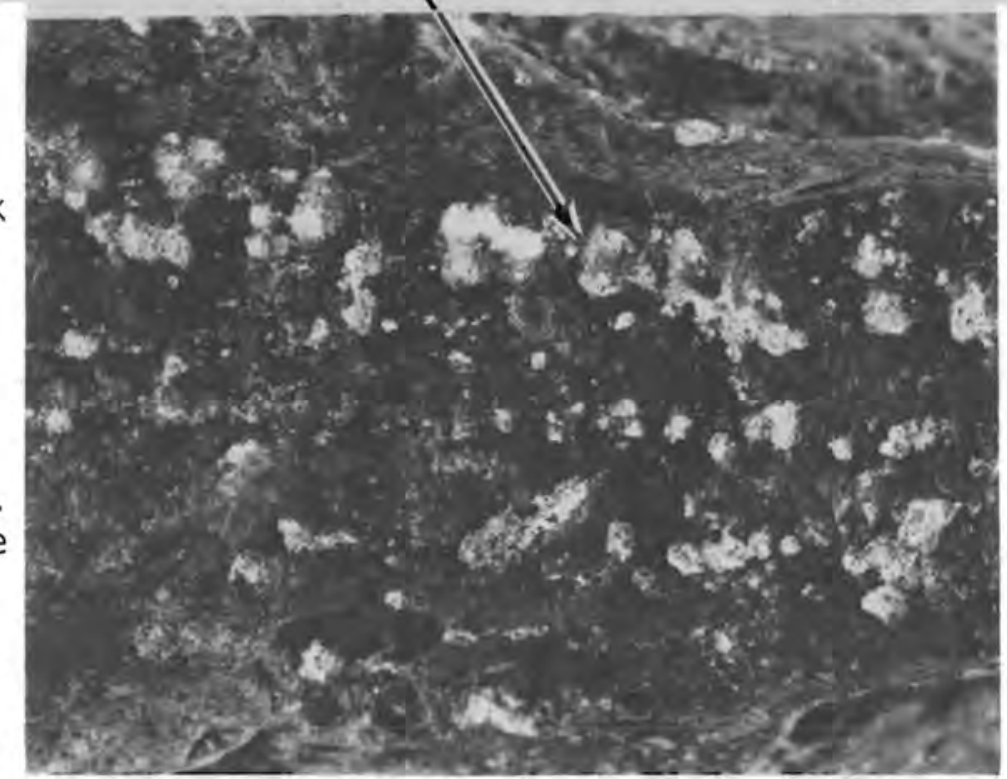

b. Neg. No. $4 \mathrm{P} 1077 \mathrm{X}$ Bottom 0.5X metal.

FIGURE 5.4. Copper Boulder A Found in Glacial Moraine Near Hancock, Michigan. The Boulder Weight is $4,215 \mathrm{~g}$; the Length is 29 in $(23 \mathrm{~cm})$; It Has Striations Appearing To Arise From the Glacial Action (See Arrows 1 and 2) 
Tabs of metal along the periphery were bent, also apparently by the glacier (Nos. 3, 4, and 5). A depression (No. 6) had residual quartz on the surface, suggesting that the copper had interfaced with a quartz mineral, which spalled off during the glaciation. The quartz layer was identified by $x$-ray diffraction.

Figure 5.5 shows an expanded view of a section cut from copper boulder A. A ridge and furrow appearing to be caused by glacial abrasion are evident on the upper surface (C). Figure 5.6 shows views of the upper (C) and lower (D) surfaces of the copper mass. The left-hand view (a) shows maximum oxide thicknesses of 0.07 to $0.46 \mathrm{~mm}$ on the upper surface and up to $0.75 \mathrm{~mm}$ on the lower surface. Several voids are apparent in the metal near the upper surface. The right-hand (etched) views show the metal structure. The upper surface of $b$ shows a local area of gross metal distortion (*) by glacial abrasion. The lower surface shows no evidence of grain distortion. The irregular lower surface therefore appears to have developed from corrosion rather than from glacial action.

Figure 5.7a shows a cross-section cut from Area 2, Figure 5.4. Again, the section is metallic, with only a thin oxide layer. The glacial striations are shallow and are not visible in cross-section on Figure 5.5. The metal tab on the right ( $b$ and $c$ ) appears to have been bent. The maximum oxide thickness on the tab surfaces is $20.2 \mathrm{~mm}$. The etched view (c) shows substantial metal distortion, presumably from glacial action. Other bent metal tabs are called out on Figure 5.4 (Areas 3,4, and 5).

Figure 5.8 shows a view of a sma11 piece of float copper weighing $300 \mathrm{~g}$ (Boulder B). This copper mass also shows evidence of glacial abrasion (indicated by arrows). Figure 5.9 shows a cross-section (A-B) which includes the abraded areas (see arrows). The as-polished copper surface (a) on unabraded areas shows blooms of oxide up to $2 \mathrm{~mm}$ thick. On the abraded areas, the oxide was thinner $(0.15$ to $0.6 \mathrm{~mm})$. This implies that corrosion over a longer span of weathering is represented by the unbraded areas, while the corrosion since the abrasion occurred (a minimum of 28,000 years) is represented by the thinner, more uniform oxide. The etched view (b) generally reflects metal distortion in areas where glacial abrasion was apparent. 


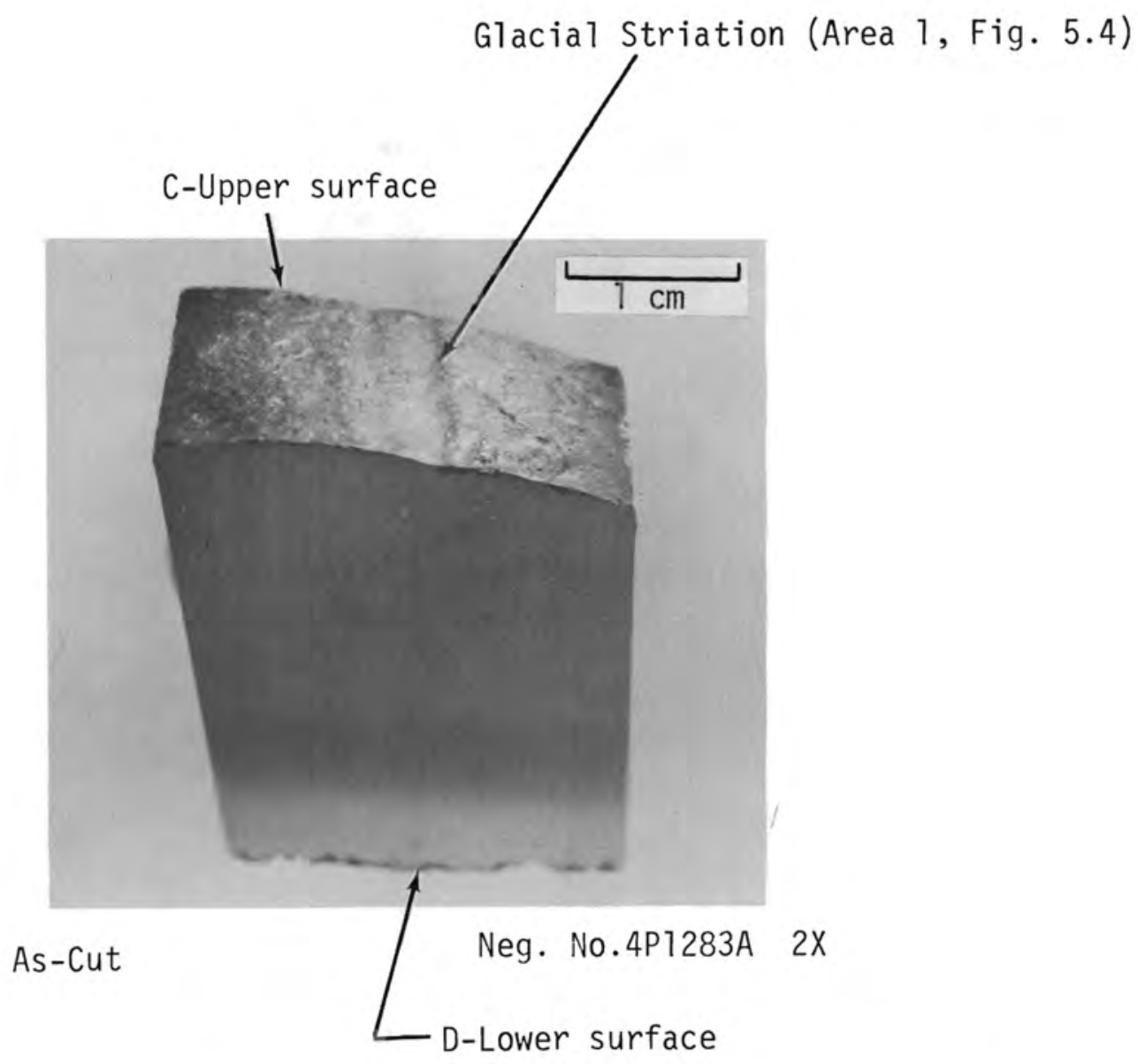

FIGURE 5.5. Section Cut From Copper Boulder, Figure 5.4 


\section{c. Upper Surface}

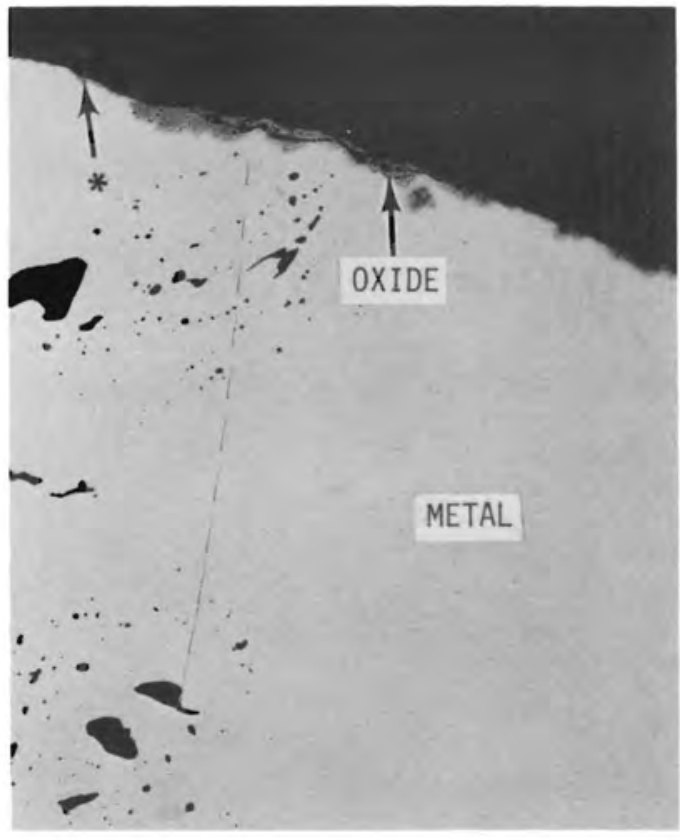

Neg. No. 4P1283D, 6.3X

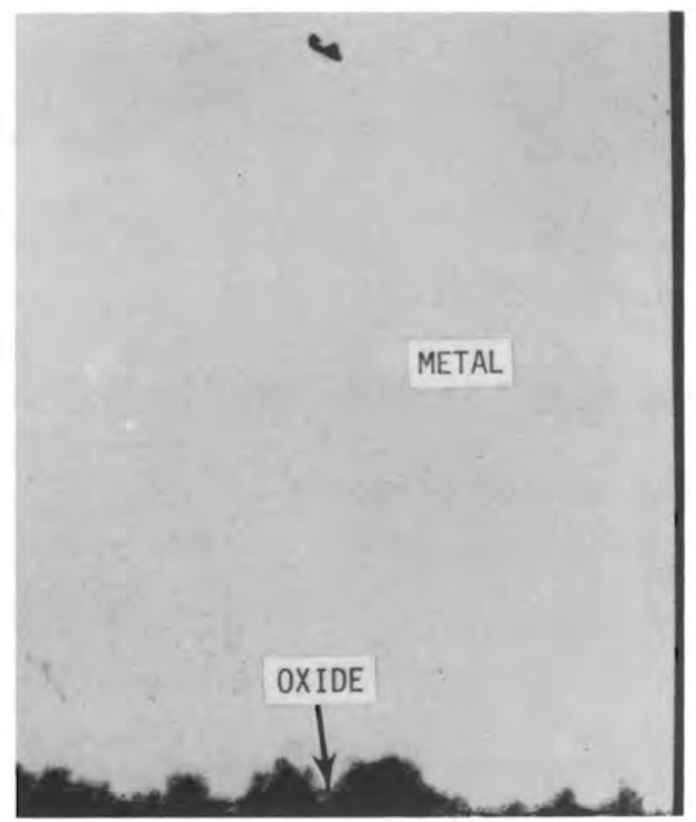

Neg. No. 4P1283G, 6.3X

d. Lower Surface

a. As-polished

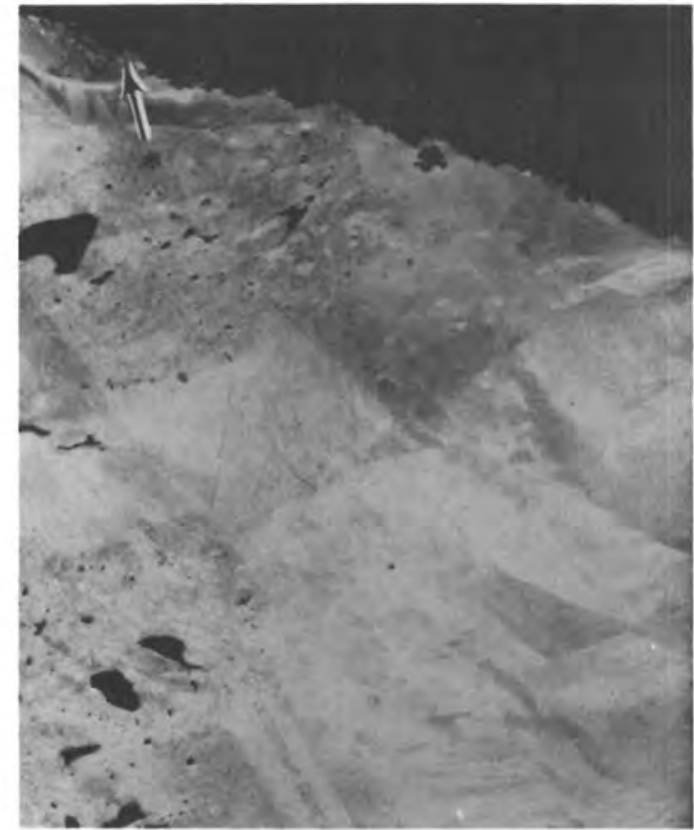

Neg. No. 4P1283L, 6.3X

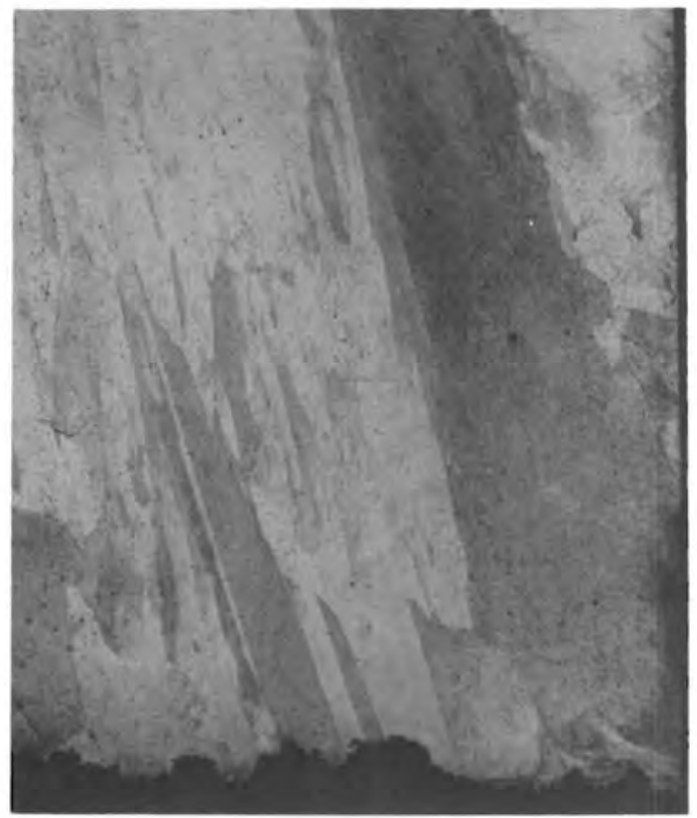

Neg. No. 4P12830, 6.3X

b. Etched

FIGURE 5.6. Expanded Views of Copper Surfaces From Figure 5.5 (Copper Boulder A) 


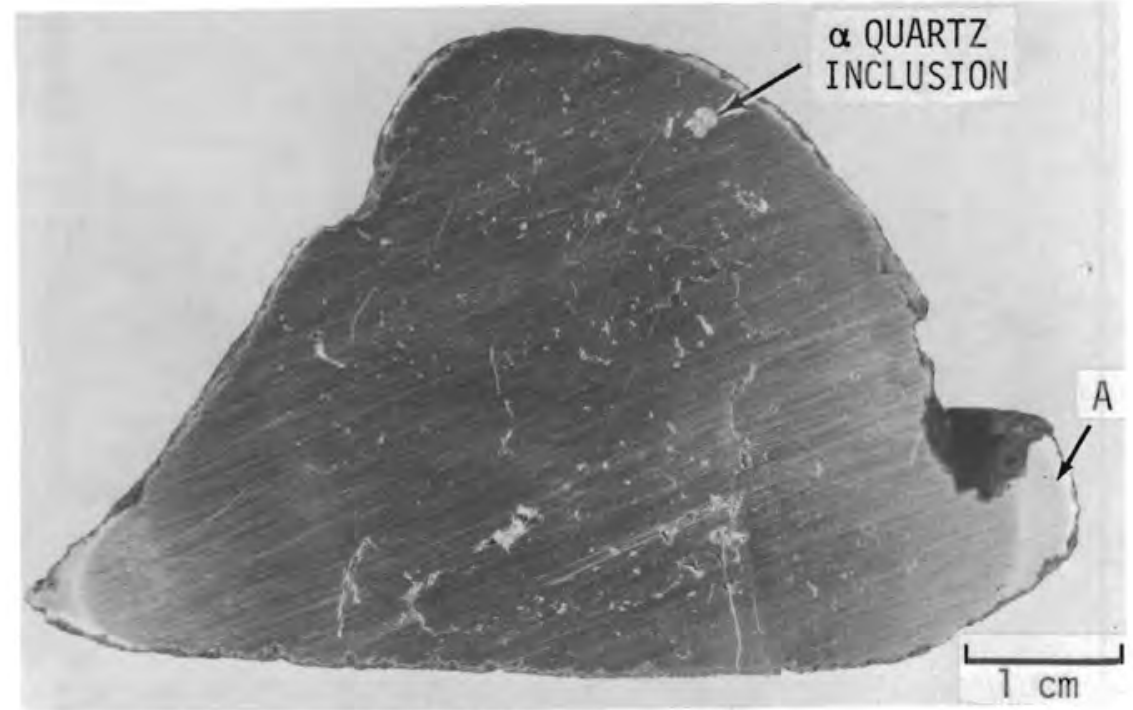

As cut (a) Neg. No. 4P1281A 1.6X

FIGURE 5.7. Cross-Section From Copper Boulder A, Figure 5.1, Area 2 


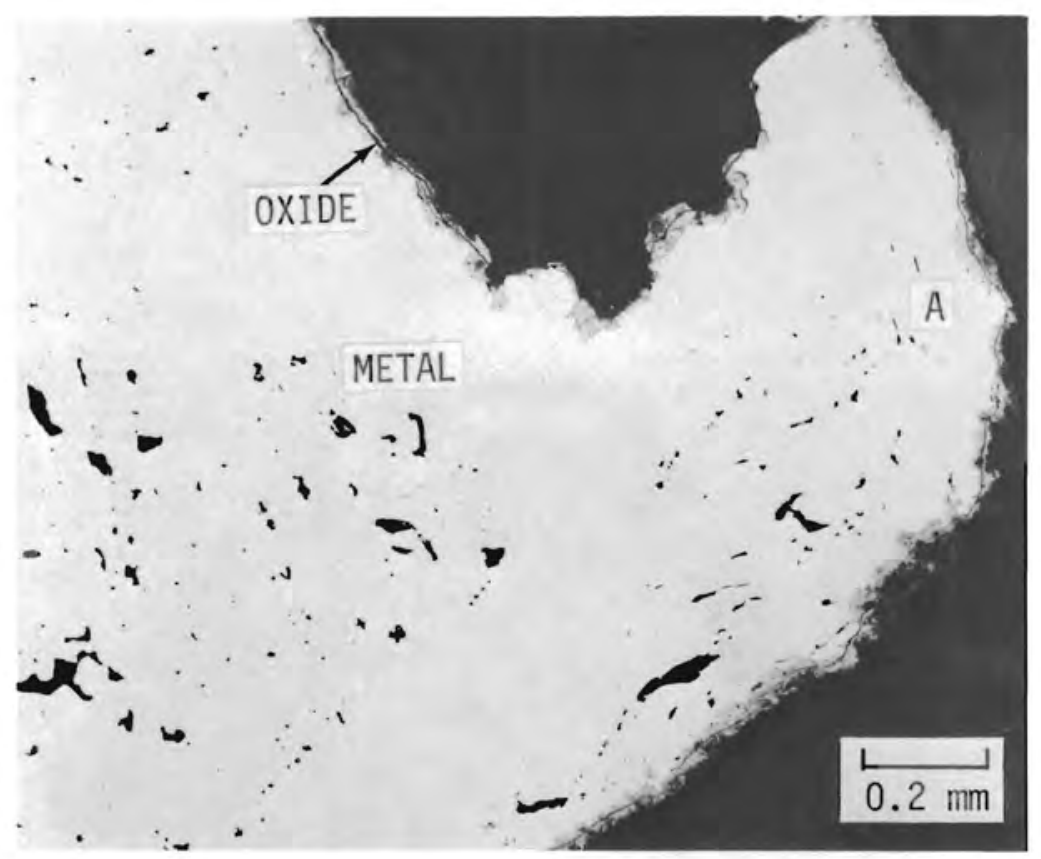

As polished (b) Neg. No. 4P1282C 6.3X

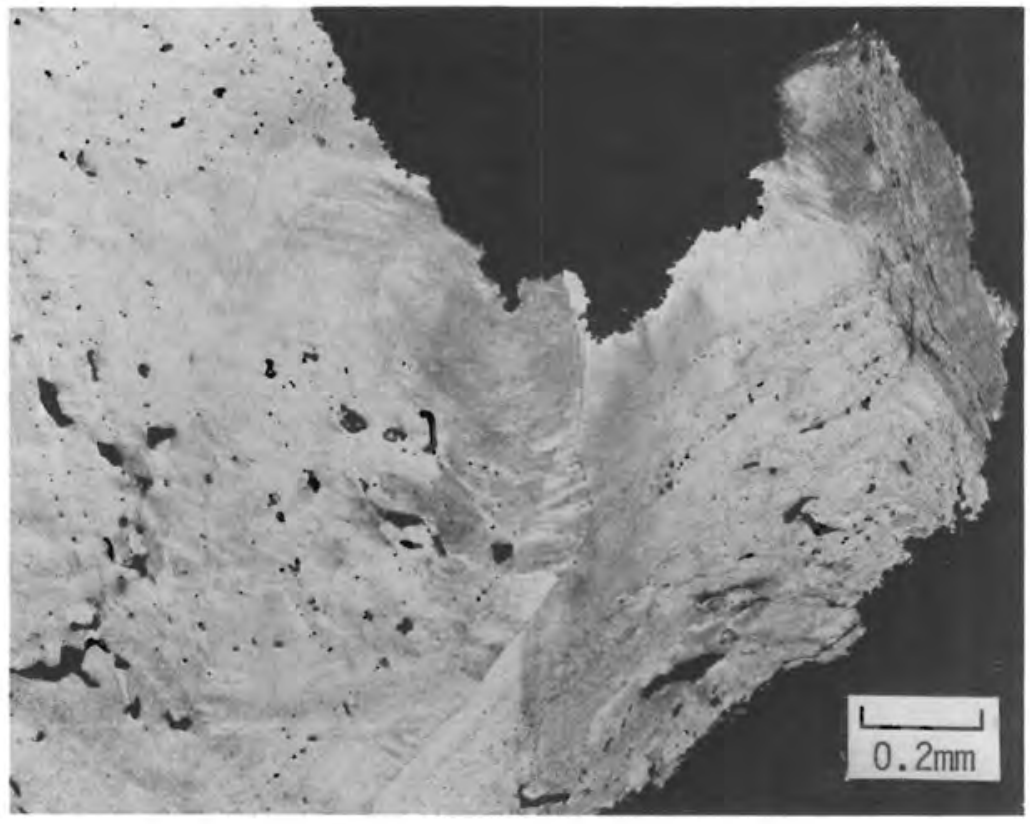

Etched (c) Neg. No. 4P1282I 6.3X

FIGURE 5.7. (contd) 


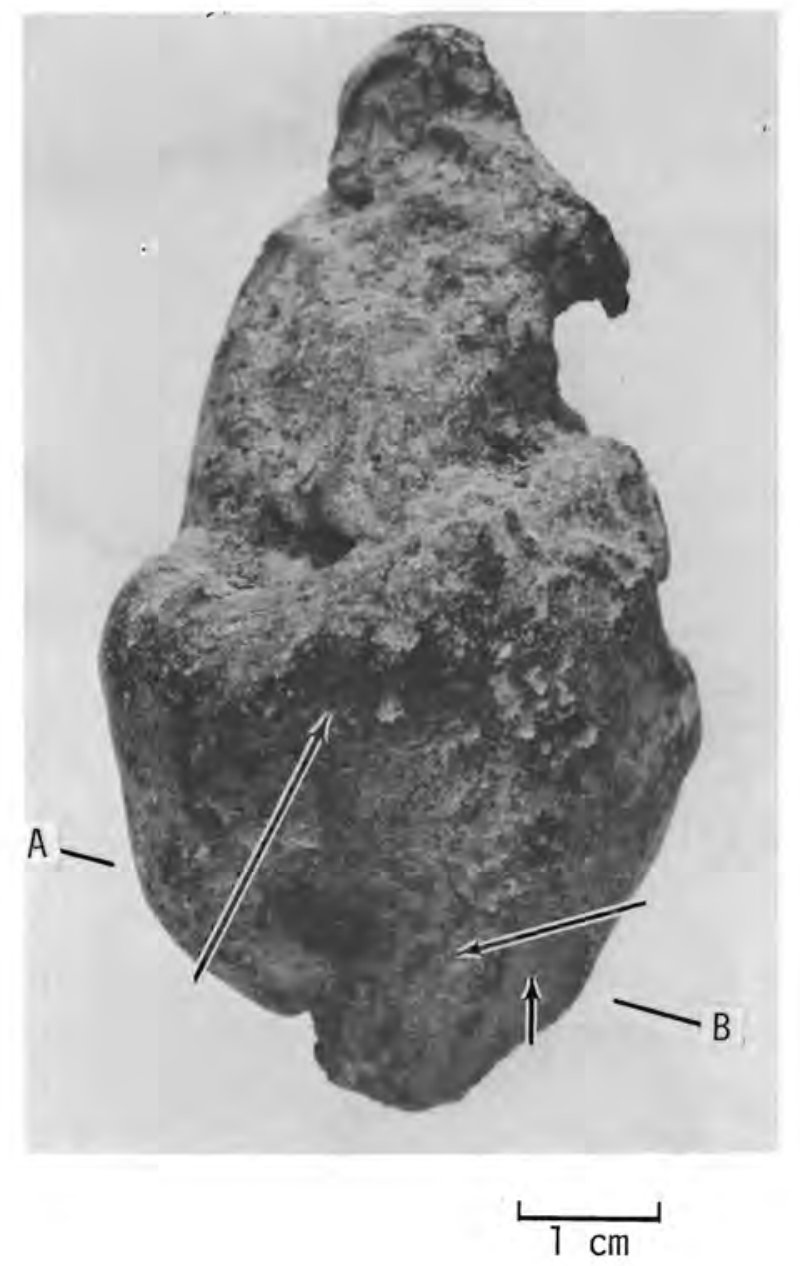

Neg. No. 4P1077A $1.4 \mathrm{X}$

FIGURE 5.8. Native Copper Boulder B Found Near Hancock, Michigan; Transported From Michigan Copper Beds By Pleistocene Glaciers (Probably $>8,000$ Years Ago); Boulder Weight is $\sim 300 \mathrm{~g}$; Areas Appearing to Represent Glacial Abrasion Are Indicated by Arrows 


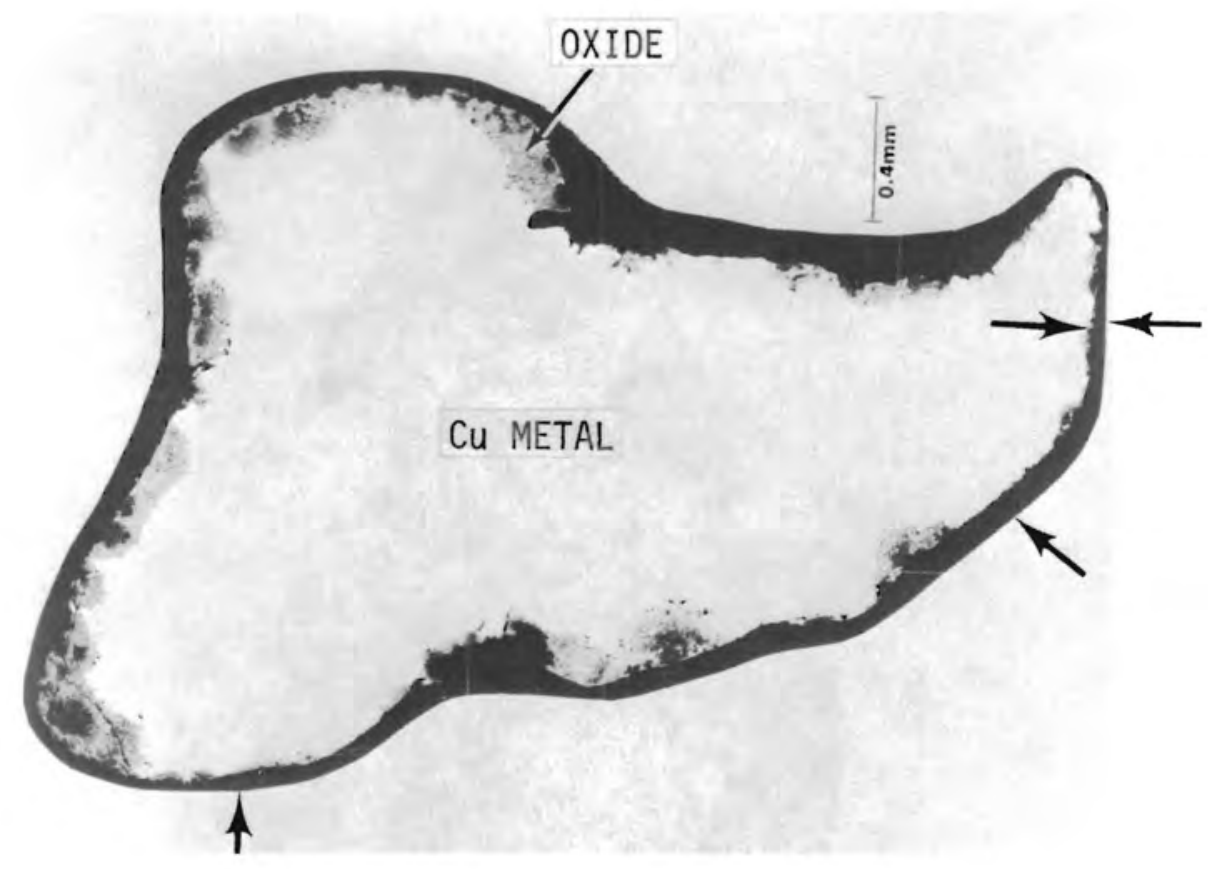

As polished (a) Neg. No. 4P1077H-1

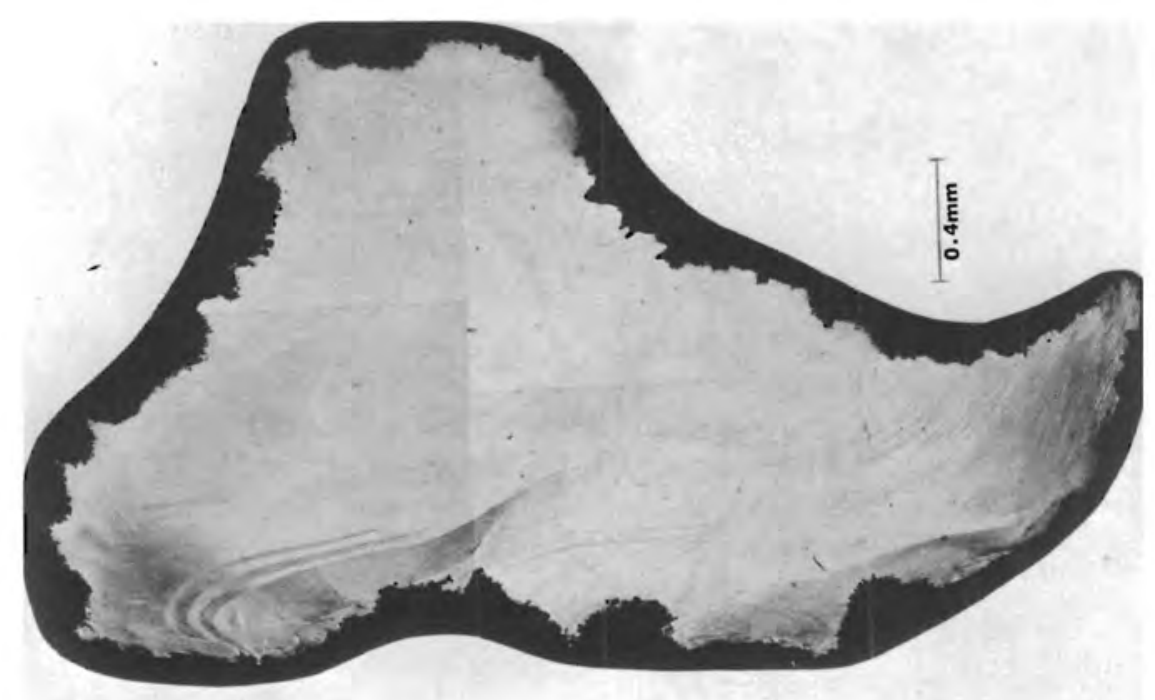

Etched (b) Neg. No. 4P1077I-1

FIGURE 5.9. Polished (a) and Etched (b) Section (A-B) of Copper Mass Shown in Figure 5.8; Arrows Indicate Areas of Glacial Abrasion 
At some locations, copper oxides on the boulders are duplex (Figure 5.10). $X$-ray diffraction indicates that the outer layer (blue-green) is malachite $\left(\mathrm{CuCO}_{3} \cdot \mathrm{Cu}(\mathrm{OH})_{2}\right)$. The inner layer is dark red-brown cuprite $\left(\mathrm{Cu}_{2} \mathrm{O}\right)$. At some locations, a thin layer of cuprite is the only oxide phase.

The two copper boulders were found near the same location, at Hancock, Michigan (Figure 5.i). However, the oxide morphologies differ somewhat. Boulder $A$ has maximum oxide thickness of $\omega .5 \mathrm{~mm}$ on the glaciated surfaces. Boulder $B$ also had a similar maximum oxide thickness $(0.6 \mathrm{~mm}) \mathrm{cn}$ the abraded surfaces. Both boulders had much thinner average oxide thicknesses on the abraded surfaces. Boulder $B$ had blooms of thicker oxide at locations away from the abrasion. The oxide blooms on Boulder B appear to represent corrosion which occurred prior to the glacial abrasion. Why the thicker oxide blooms did not occur on Boulder $A$ is not clear.

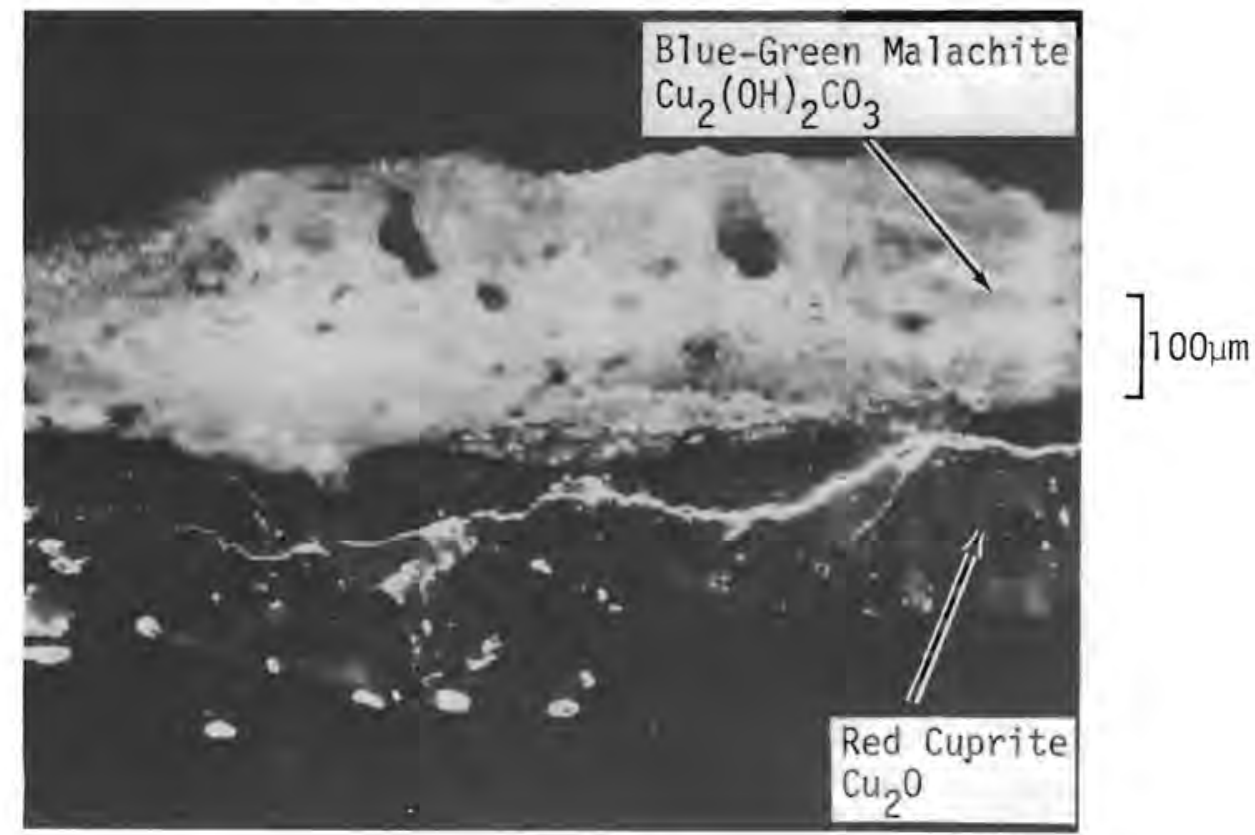

FIGURE 5.10. Duplex 0xide on Copper Boulder A 


\subsection{REFERENCES}

1. The New Encyclopedia Britannica. 15th Edition, University of Chicago, 1976.

2. R. W. Drier and 0. J. DuTemple, eds. Prehistoric Copper Mining in the Lake Superior Region. Published by the authors, 2nd printing, 1965.

3. A. LaBastille. "On the Trail of Wisconsin's Ice Age." Nat. Geog. August 1977.

4. R. F. Tylecote. A History of Metallurgy. The Metal Society, London, 1976.

5. The World Book Encyclopedia. Field Enterprises Corporation, New York, Vo1. 15, 1965.

6. A. Topping. "China's Incredible Find." Nat. Geog. 153:440-462, Apri1 1978.

7. The Ore Bin. 24:6, June 1962, pp. 83, 85; a 1so 11:10, October 1949, p. 68. Published by the State of Oregon, Department of Geology and Mineral Industries.

8. I. R. Selimkhanov. Sur 1'Etude du Fragment de Vase de Tello Appartenant au Musée du Louvre et le Probleme, de l'Utilisation de l'antimoine dans 1 'antiquite, Laboratoire de Recherche des Musee de France, pp. 45-52, Annales, 1975.

9. The Ontanagon Copper Boulder. Smithsonian Institution Press, Washington, DC, 1971 . 



\subsection{LONG-TERM METAL DURABILITY}




\subsection{LONG-TERM METAL DURABILITY - DISCUSSION}

Corrosion and weathering characteristics of archaeological artifacts, metal meteorites, and native metals were summarized in the foregoing sections. This section integrates corrosion and weathering observations from the three sources and considers factors which appear to promote metal durability.

\subsection{ANCIENT METAL UTILIZATION}

From the standpoint of utilization, the seven metals of antiquity have a varied history. Gold and silver are durable, but not plentiful. Neither has attractive mechanical properties for weapons and implements. Copper, iron and their alloys have been plentiful and widely utilitarian. Lead, with low mechanical strength and a dingy appearance, had relatively widespread, but specialized uses. Tin, while valuable as an alloy addition to produce bronze, was not widely used as a separate metal. Ancient metallurgists were aware of amalgams, and some liquid mercury was used in Chinese tombs, but mercury was a minor archaeological metal.

Meteoritic iron was an early but not large source of ferrous artifacts.

On volume, copper has been by far the most important native metal. Native ores are important sources of gold and to a lesser extent, silver. They have been a minor source of archaeological iron and have not provided sources of lead and tin.

\subsection{SUMMARY OF METAL DURABILITY}

Gold has been durable in essentially every environment. Silver, while durable in most environments, including seawater, has been subject to some corrosion, particularly by chlorides.

Copper has an impressive record of durability on land and in seawater. Float copper having evidence of glacial action has shown low rates of postglacial corrosion. Bronze, with better mechanical properties also has survived for up to five millenia in favorable environments. Tylecote ${ }^{(1)}$ indicates that bronze canisters could be engineered for use in seawater for at least 1,000 years. 
Over the centuries, archaeological iron appears to be less durable than the other materials mentioned above. Even so, ferrous materials have shown impressive durability in several environments, exemplified by the iron articles in the Tutankhamen tomb (1300 BC), the iron pillar of Delhi (400 AD), and cast iron water pipes (Versailles, France, since $1665 \mathrm{AD}$ ). Metal (Fe-Ni) meteorites show a wide variety of corrosion responses, but some with estimated terrestrial ages of 5,000 to 20,000 years have survived impressively. However, Tylecote ${ }^{(1)}$ was not impressed with iron durability in seawater.

Lead sheathing on ancient ships and in Roman water systems held up sufficiently well to merit recommendation for 1,000 year service in seawater. (1)

Tin has not held up well in seawater, ${ }^{(1)}$ but a tin bracelet dated to $2500 \mathrm{BC}$ appears to be well-preserved. Pewter has held up quite well in seawater over several centuries.

\subsection{FACTORS IN METAL DURABILITY}

An in-depth analysis of ancient metal durability in terms of kinetic and thermodynamic factors is complex due to uncertainties in environments, metal compositions, and metallurgical factors. However, several insights to metal durability are worthy of mention.

\subsubsection{Metallurgical Processes}

Welding has ancient beginnings. Gold, silver, electrum, and copper were joined by welding within the third millenium $B C .{ }^{(3)}$ Nails and rivets were used from $23000 \mathrm{BC}$ made from several materials, including gold and iron. By the fifth or sixth century $B C$ the Persians were using iron draw plates to make wires. The Romans used soldering to join bronze. For soft soldering, they used the non-corrosive eutectic of lead and tin.

\subsubsection{Environments}

Restricted oxidant or water supply was a factor in the survival of some metals: 
- Iron articles buried in sea mud, (4) where the environment may be largely anaerobic.

- The iron dagger wrapped with the King Tutankhamen mummy.

- The iron nails in a Roman nail hoard (Ref. 4, p. 33) where oxidant gettering by the outer layers of nails protected the inner nails since 285 AD.

Dry tombs were a favorable environment for essentially all the ancient metals. Infrequent moisture intrusions to the King Tutankhamen tomb contributed to rusting of miniature iron implements, but they were not fully consumed in 33 centuries. (5) Either dryness or wet anaerobic conditions are favorable for long-term durability of iron-base materials, consistent with current understandings. (6)

Metals exposed directly to the elements include the metal meteorites, native metals, statuary and building adornments. The metal meteorites have tended to survive best at drier locations. Some copper articles and bronze statuary have survived well in moist environments in direct exposure to the elements. However, deleterious effects of pollution from modern sources has been severe in some locations. For example, guilded bronze statuary exposed 2,000 years in the moist Venice, Italy environment only began to deteriorate rapidly when sulfur dioxide levels rose, requiring extensive restoration and protective measures, including, in some cases, removal to less aggressive environments.

Burial in soils has been among the more severe environments for most metals. Iron, including the metal meteorites, has not fared well in most soils. Coppers and bronzes have been more resistant than the irons in soils. In fact, copper boulders buried in glacial outwash (Figures 5.4 and 5.8) survived in good condition over what appears to have been $>8,000$ years.

We have previously noted that in seawater, copper, bronze, gold, silver, and lead have had impressive multi-century durabilities. Iron and tin resistance to seawater has been less than impressive.

\subsubsection{Galvanic Factors}

Early shipbuilders apparently learned the hard way that iron nails were not a satisfactory means for attaching lead sheath to the ship exterior. 
Examination of the Argosy wreck ${ }^{(7)}$ suggested that experience was a good teacher. Copper nail heads holding lead sheets to the hulls had been sheathed with lead. In high-conductivity waters, galvanic factors must always be a prime concern. Examples of costly oversights in modern shipbuilding and numerous other applications can be cited. In drier environments there are many examples where metal couples have appeared to endure for centuries.

Interesting galvanic relationships have been observed among phases in the metal meteorites. Buddhue ${ }^{(6)}$ has measured potentials between selected phases, as indicated earlier. Corrosion over centuries has consumed kamacite (Fe, $7.5 \% \mathrm{Ni}$ ), while preserving phases such as taenite ( $\mathrm{Fe}, 25 \% \mathrm{Ni}$ ), schreibersite $(\mathrm{Fe}, \mathrm{Ni})_{3} \mathrm{p}^{(\mathrm{a})}$ and draubreelite $\left(\mathrm{FeCr}_{2} \mathrm{~S}_{4}\right)$. Sacrificial kamacite corrosion undoubtedly contributed to the endurance of the more cathodic phases. However, some metal inclusions are found in otherwise fully-oxidized meteoritic material, suggesting that the phases have inherent corrosion resistance beyond the galvanic protection.

\subsubsection{Protective Coatings}

Some ancient metallurgists appear to have grasped some principals of metal protection. Gold leaf was used as early as the third millenium BC. Whites of eggs were used for attachment. Hot guilding was applied with a gold amalgam. Copper and bronze were treated with mercury to form surface amalgams. Resorts to trickery were used to make less valuable metals take on the appearance of gold. Copper and bronze formed natural, attractive patinas. However, Phoebe Dent Weil of the Archaeometry Dept., Washington University, St. Louis, Missouri, U.S.A., indicates that natural patinas often are not highly protective. Some bronze objects were dipped hot into molten resins, forming attractive tints and providing protection from corrosion. The corrosion resistance of tin was recognized by the ancients and a process of "tinning" (hot dipping in molten tin) was developed about the second century $\mathrm{BC}$, to copper and bronze and later to brass. The corrosion resistance of lead also was recognized, resulting in use for water systems by the Romans,

(a) Identified by Buchwald as the meteorite mineral most resistant to terrestrial corrosion. (8) 
though possibly with dire results to their health. Some copper and bronze articles were lined with solder or lead for protection. For protection of iron and steel, some tinning was used, but non-metallic coatings were more common. ${ }^{(3)}$ The preservatives included liquid tar, bitumen, red lead, white lead, and gypsum.

A recent description of a massive Chinese archaeological find mentions that a "protective coating" preserved bronze weapons and implements over 22 centuries, though there was no indication of the nature of the preservative.

The probable protective character of the fusion crust on metal meteorites was indicated in Section 4.6. The fusion crust is a magnetite-wustite layer formed by rapid oxidation of the metal surface in the earth's atmosphere. The durability $^{(\mathrm{a})}$ of the Iron Pillar of Delhi $(99.7 \% \mathrm{Fe})$ is attributed to a relatively dry environment with minimal impurities. However, the pillar was constructed by forge-welding together many solid disks. Conditions during welding may have been favorable for formation of corrosion-resistant oxides. Metal nails, an early precious commodity, sometimes were recovered by burning abandoned structures. This formed high-temperature oxides which appear to have been protective.

Some metals have survived burial in bogs and in the wooden hulls of sunken ships. While partial anaerobic conditions may have been a factor, tannins probably acted as corrosion inhibitors. In fact, use of tannins as modern corrosion inhibitors evolved from the observations.

\subsection{SOME PERSPECTIVES FROM THE STUDY}

The principal conclusion of this study is that selected metals have survived for centuries and even millenia in a variety of natural and man-made (tomb, grave, etc.) environments. On one hand, this realization may counter our general skepticism regarding metal durability, engendered by examples of rusting autos and leaking pipes. On the other hand, the observations do not represent a license for unwarranted extrapolations. However, the data have potential value as a baseline and a starting point for extrapolations.

(a) Another iron pillar in the same vicinity (Dhara) toppled over many years ago. (2) Whether it was due to deterioration is not clear. 
We have made some attempt to quantify corrosion rates, from the archaeological literature. and from direct and published evaluation of corrosion on metal materials and native copper. We regard this as a preliminary effort, and invite corrections and additions from those with knowledge of the corrosion behavior of specific materials.

Clearly there is a need for better correlation of corrosion with the archaeological environment (often not well-defined) and factors such as metal composition and metallurgical condition.

Our analysis indicates a broad range of corrosion rates. Future focus might expand on our preliminary analys is of the factors which contributed to the minimum rates.

We have performed some extrapolations of corrosion data on modern materials, to compare with estimated corrosion rates on related ancient materials (Section 3.1). These suggest eventual corrosion rates for the modern materials which fall near the mid-ranges of corrosion on the ancient materials. Again, specialists in the corrosion of certain modern materials may suggest different bases for extrapolation.

Those who select materials for installations which benefit from or require long-term durability may find some useful insights here. For example, the economics of solar collectors and mounting stands would benefit from multidecade guarantees. In some cases, there is a tendency to settle for inexpensive materials, often sacrificing durability. On the other hand, specification of more expensive materials with multi-century credentials must not be made without due caution. Siting of otherwise durable materials in contaminated environments has caused expensive and untimely replacement. Even such aspects as inappropriate cleaning methods have negated the inherent durability of industrial materials.

In the nuclear waste multi-barrier concept, canisters interface with high level waste or spent fuel on one side. On the other side, the canister or its overpack interfaces with a backfill or with the geologic environment. The canister is expected to contain the waste for several centuries. While we can 
now point to materials with proved multi-century credentials, effects of elevated temperatures and radiation also must be accounted for.

We shall briefly consider some aspects of the extrapolations necessary to evaluate materials for the intended canister application.

Several types of disposal sites have been considered for nuclear wastes, including sea beds, salt domes, rock formations (basalt, granite, shale, tuffs) and near-surface engineered storage.

Metal durability in the largely anaerobic conditions in sea mud has been relatively good. However, effects of elevated temperatures and radiolysis add some complexity to the interpretation. Because a salt dome environment is now considered to be prone to moisture intrusions, some similarities to sea water can be presumed. Combined thermal and radiolytic effects in saline environments largely remain to be evaluated.

Engineered dry storage appears to us to minimize uncertainties in the materials behavior extrapolations. First, the temperatures and radiation levels in a geologic repository are to some extent controllable by selection of canister density and waste content. Dry and tomb-like environments were clearly the most benign toward all of the ancient materials. It may be unrealistic to expect dryness over several centuries, though instances of dryness for much longer periods are indicated for selected tombs (e.g., Ramases VI). (5) However, some mild moisture intrusions could be tolerated. Dry cooling tower technology (10) and related fundamental studies $(11)$ indicate that corrosion rates at temperatures above the dew point are lower than room temperature corrosion rates for a variety of materials in moist atmospheric exposures. This occurs by suppressing moisture condensation, thereby suppressing corrosion. Thus, if the temperatures are below the range where rapid oxidation occurs, elevated temperatures are in fact an advantage.

Estimation of radioactivity effects on canister degradation also seem to us to be more straightforward in a dry or at least non-liquid environment, where the elevated temperature will minimize moisture interactions with the metal surface. Thus, extrapolations of the baseline long-term durability data 
provided in this study appear to us to develop most readily for a dry or mildly moist repository environment. Both Egyptian and Chinese tomb builders have demonstrated that dryness can be achieved. An interesting case in point involves a Chinese noblewoman buried near Ch'angsha about 2,100 years ago. (12) Her buriers achieved an air-tight, relatively dry, anti-fungicidal ${ }^{(a)}$ environment. Not only was the silk well preserved, but the woman's skin was still elastic, the joints were mobile and the hair was still attached. The favorable burial environment was achieved by:

- five tons of charcoal to adsorb external moisture

- a layer of white clay two to four feet thick

- layers of wooden caskets

- 20 layers of silk

Numerous remote, relatively dry locations exist in the U.S. It is relevant to note that the Austrians were negotiating for a nuclear waste storage site in the Egyptian desert before the political demise of the Austrian commercial nuclear program.

Some of the ancient materials provide attractive candidates for waste storage applications. Swedish investigators regard copper and lead as good candidates for terminal storage of unreprocessed fuel. (10) Both metals have direct ties to the ancient metals. One investigator has proposed a scenario which utilizes a very thin gold coating to preserve waste canisters that are charged with very long-lived radioisotopes, such as $\mathrm{Np}$ and Am. ${ }^{(11)}$ Some of the resistant phases in the metal meteorites appear to deserve additional consideration for multi-century applications.

(a) Mercury compounds were identified. 


\subsection{REFERENCES}

1. R. F. Tylecote. Durable Materials for Seawater: The Archaeological Evidence. British Nuclear Fuels Limited (BNFL), Report 314 (R), 1977.

2. L. Aitchison. A History of Meta1s. Vol. 1, Interscience Publishers, New York, NY, 1960.

3. J. G. Parr. Man, Metals and Modern Magic. American Society for Metals and Iowa State College Press, Armes, IA, 1958.

4. Corrosion and Metal Artifacts. NBS Special Publication 479, U.S. Department of Commerce, National Bureau of Standards, Washington, DC, July 1977 , pp. 155-166.

5. H. Carter. The Tomb of Tutankhamen. Excalibur Books, 1954.

6. J. D. Buddhue. The Oxidation and Weathering of Meteorites. University of New Mexico Publications in Meteoritica, No. 3, Albuquerque, NM, 1957.

7. J. Cousteau. "Fish Men Discover a 2,000 Year 01d Greek Ship." Nat. Geog. CV:1-36, January 1954.

8. V. F. Buchwald. "The Mineralogy of Iron Meteorites." Phil. Trans. R. Soc. Land. A, 286:453-491, 1977.

9. A. Topping. "China's Incredible Find." Nat. Geog. 153:440-462, Apri1 1978.

10. A. B. Johnson, Jr., D. R. Pratt and G. E. Zima. A Survey of Materials and Corrosion Performance in Dry Cooling Applications. BNWL-1958, Battelle, Pacific Northwest Laboratories, March 1976.

11. P. J. Sereda. "Weathering Factors Affecting Corrosion of Metals." Corrosion in Natural Environments. ASTM-STP-558, American Society for Testing and Materia1s, 1-22, 1974.

12. A. J. Hal1. "A Lady from China's Past." Nat. Geog. 145:661-681, May 1974.

13. "Handling and Final Storage of Unreprocessed Spent Nuclear Fuel." Vol. I and Vol. II, Kärnbränslesäkerhet, Stockholm, Sweden, 1978.

14. Gösta Wranglén. "Gold and Selective Storage Solves Nuclear Waste Problem." Annals of Nuclear Energy. 4:527-528, 1977. 


\subsection{SUGGESTIONS FOR RELATED ACTIVITIES}




\subsection{SUGGESTIONS FOR RELATED ACTIVITIES}

The number of metallic archaeological objects is vast. This study has only probed the surface of the potential store of metal durability information. However, quantification and interpretation of ancient metal corrosion often are difficult. The archaeologists' first priorities are preservation and restoration, both of which may thwart the interests of the corrosion scientist. Few archaeological digs document all information (soil pH, for example) which is important to corrosion evaluations.

The dialogue between corrosion scientists and archaeologists has begun, (1) but only barely. However, in our limited individual contacts to archaeologists, meteoriticists and geologists, the cooperation was excellent in requests both for information and specimens, suggesting that a basis for further mutually useful interaction exists. We believe that much additional specific information regarding metal durability can be derived by a more thorough assessment of metal artifacts. A much more quantitative basis for artifact corrosion evaluation could evolve by more extensive involvement of specialists than was permitted by the scope of this study. Likewise, evaluation of long-term meteorite and native metal corrosion could benefit by more direct involvement of specialists.

The history of the modern metals is relatively short. Even so, a quantitative definition of their behavior over several decades may be feasible in selected environments, as a basis for extrapolation. For example, the stainless steels have been in production since 21900 . Titanium was first produced in relatively pure form in 1910. The corresponding date for zirconium was 1914 . Prospects are good that the corrosion behavior of modern materials over several decades can be determined.

Combined effects of temperature and radiation on materials behavior are not readily available for saline environments. However, there are reactor components still in operation which have been on line since 1956 (Calder Hall), 1957 (Shippingport) and 1960 (Dresden-1). The sum of potential data from these and similar systems is substantial in terms of material types, temperature 
ranges, radiation levels, and environments (gas and liquid). Inspection and examination of selected components, combined with the substantial body of existing data, could provide a basis for evaluating thermal and radiation effects in waste management scenarios.

Several observations from this study deserve further consideration: the possible protective character of surface oxides such as the fusion crust on meteorites and high-temperature films on the Pillar of Delhi and on ancient iron nails; further consideration of the durable nature of metallic inclusions in the oxides on weathered meteorites; some suggestions that pure copper is more durable than copper alloys. 


\subsection{REFERENCES}

1. "Corrosion and Metal Artifacts - A Dialogue Between Conservators and Archaeologists and Corrosion Scientists." NBS Special Publication 479, U.S. Department of Commerce, Washington, DC, July 1977.

2. H. Carter. The Tomb of Tutankhamen. Excalibur Books, 1954. 


\section{DISTRIBUTION}

No. of

Copies

UNITED STATES

A. A. Churm

DOE Chicago Patent Group

9800 South Cass Avenue

Argonne, IL 60439

R. E. Cunningham, Deputy Director

Div. of Fuel Cycle and Materials

Office of Nuclear Safety

Materials and Safeguards

Room 562

Nuclear Regulatory Commission

7915 Eastern Avenue

Silver Springs, MD 20910

J. B. Martin

Assistant Director for Radioactive Waste Management Branch

NRC Division of Materials and

Fuel Cycle Facility Licensing

Washington, DC 20555

D. M. Rohrer

High-Level Waste Technical Development Branch

Nuclear Regulatory Commission

Washington, DC 20545

W. G. Belter

DOE Division of Biomedical and

Environmental Research

Earth Sciences Branch

Washington, DC 20545

W. E. Mott

DOE Division of Environmental Control Technology

Washington, DC 20545

C. R. Cooley

DOE Office of Nuclear Waste

Management

Washington, DC 20545
No. of

Copies

C. H. George

DOE Office of Nuclear Waste Management

Washington, DC 20545

C. A. Heath

DOE Office of Nuclear Waste Management

Washington, DC 20545

G. Oerte1

DOE Office of Nuclear Waste

Management

Washington, DC 20545

A. F. Perge

DOE Office of Nuclear Waste Management

Washington, DC 20545

D. L. Vieth

DOE Office of Nuclear Waste Management

Washington, DC 20545

R. D. Walton

DOE Office of Nuclear Waste

Management

Washington, DC 20545

J. Neff, Program Manager

Department of Energy

Columbus Program Office

505 King Avenue

Columbus, $\mathrm{OH} 43201$

DOE Idaho Operations Office

P.0. Box 2108

Idaho Falls, ID 83401

J. B. Whitsett

DOE Idaho Operations Office P.0. Box 2180

Idaho Falls, ID 83401 
No. of

Copies

E. S. Goldberg

DOE Savannah River Operations Office

P.0. Box A

Aiken, SC 29801

T. B. Hindman, Sr.

DOE Savannah River Operations Office

P.0. Box A

Aiken, SC 29801

27 DOE Technical Information Center

G. L. Ritter

Exxon Nuclear Idaho

P.0. Box 2800

Idaho Falls, ID 83401

Exxon Nuclear Idaho

(File Copy)

P.0. Box 2800

Idaho Fal1s, ID 83401

A. L. Taboas

TRU Waste Management Program

DOE A1buquerque Operations

Office

P. 0. Box 5400

Albuquerque, NM 87185

J. A. Buckham

Allied-General Nuclear Services

P.0. Box 847

Barnwell, SC 29812

A. Williams

Allied-General Nuclear Services

P.0. Box 847

Barnwe11, SC 29812

J. L. Jardine

Argonne National Laboratory

9800 South Cass Avenue

Argonne, IL 60439
No. of

Copies

M. J. Steindler/L. E. Trevorrow Argonne National Laboratory 9800 South Cass Avenue Argonne, IL 60439

Battelle Memorial Institute Office of Nuclear Waste Isolation Attn: Ms. Beverly Rawles 505 King Avenue

Columbus, $\mathrm{OH} 43201$

N. E. Carter

Office of Nuclear Waste Isolation

Battelle Memorial Institute

505 King Avenue

Columbus, $\mathrm{OH} 43201$

M. Kehnemuyi

Office of Nuclear Waste Isolation

Battelle Memorial Institute

505 King Avenue

Columbus, $\mathrm{OH} 43201$

P. L. Hofman

Office of Nuclear Waste Isolation

Battelle Memorial Institute

505 King Avenue

Columbus, $\mathrm{OH} 43201$

2 Brookhaven National Laboratory

Reference Section

Information Division

Upton, Long Island, NY 11973

Combustion Division

Combustion Engineering, Inc.

Windsor, CT 06095

Lawrence J. Smith

TRU Waste Systems Office

Bldg. T-790

Rockwell International

Rocky Flats Plant

P. 0. Box 464

Golden, CO 80401 
No. of

Copies

E. Vejvoda, Director

Chemical Operations

Rockwell International

Rocky Flats Plant

P.0. Box 464

Golden, C0 80401

M. D. Boersma

E.I. Du Pont de Nemours Co. Savannah River Laboratory

Aiken, SC 29801

A. S. Jennings

E.I. Du Pont de Nemours Co. Savannah River Laboratory

Aiken, SC 29801

S. Mirshak

E. I. Du Pont de Nemours Co.

Savannah River Laboratory

Aiken, SC 29801

P. H. Permar

E. I. Du Pont de Nemours Co.

Savannah River Laboratory

Aiken, SC 29801

R. Williams

Electric Power Research Institute $3412 \mathrm{Hillview} \mathrm{Avenue}$

P.0. Box 10412

Palo Alto, CA 94304

Environmental Protection Agency

Technology Assessment Division (AW-559)

Office of Radiation Programs

U.S. Environmental Protection Agency

Washington, DC 20460

R. G. Barnes

General Electric Company

175 Curtner Avenue (M/C 160)

San Jose, CA 95125
No. of

Copies

L. H. Brooks

Gulf Energy and Environmental

Systems

P. 0. Box 81608

San Diego, CA 92138

2 Central Research Library

Document Reference Section

Oak Ridge National Laboratory (DOE)

Oak Ridge, TN 37830

3 Los Alamos Scientific Laboratory

P.0. Box 1663

Los Alamos, NM 87544

C. J. Kershner

Monsanto Research Corporation

Mound Laboratory

P. 0. Box 32

Miamisburg, $\mathrm{OH} 45342$

J. P. Duckworth, Plant Manager

Nuclear Fuels Services, Inc.

P. 0. Box 124

West Valley, NY 14171

J. L. Larocca, Chairman

Engineering Research and

Development Authority

Empire State Plaza

Albany, NY 12223

D. R. Anderson

Sandia Laboratories

Albuquerque, NM 87185

W. Weart

Division 1140

Sandia Laboratories

Albuquerque, NM 87185

0. E. Jones

Sandia Laboratories

Albuquerque, NM 87185 
No. of

Copies

J. W. Bartlett

The Analytical Sciences Corp.

6 Jacob Way

Reading, MA 01867

R. E. Blanco

Union Carbide Corporation (ORNL)

Chemical Technical Division

P. 0. Box $Y$

Oak Ridge, TN 37830

J. 0. Blomeke

Union Carbide Corporation (ORNL)

Chemical Technology Division

P.0. Box Y

Oak Ridge, TN 37830

D. E. Ferguson

Union Carbide Corporation (ORNL)

Chemical Technology Division

P. 0. Box Y

Oak Ridge, TN 37830

R. A. Beall

U.S. Department of Interior

Bureau of Mines

Albany Research Center

1450 W. Queen Avenue

Albany, OR 97321

R. G. Post

College of Engineering

University of Arizona

Tucson, AZ 85721

F. K. Pittman

3508 Sagecrest Terrace

Ft. Worth, TX 76109

\section{FOREIGN}

2 International Atomic Energy Agency

Kärtner Ring 11

P.0. Box 590

A-1011, Vienna, AUSTRIA
No. of

Copies

\author{
S. Orlowski \\ Commission of the European \\ Communities \\ Rue de la Loi 200 \\ B-1049 Brusse1s, BELGIUM \\ M. Toml inson \\ Director of Chemistry and \\ Materials Science Division \\ Atomic Energy of Canada, Ltd. \\ Whiteshell Nuclear Research \\ Establi shment \\ Pinawa, Manitoba, CANADA \\ K. D. B. Johnson \\ Atomic Energy Research \\ Establishment \\ Harwe 1 1, Didcot, \\ oxon, ENGLAND \\ D. W. Clelland \\ United Kingdom Atomic Energy \\ Authority \\ Risley, ENGLAND \\ Y. J. Sousselier \\ Centre d'Etudes Nucleaires \\ de Fontenay-aux-Roses \\ Boite Postale 6 \\ 92 - Fontenay-aux-Roses \\ FRANCE
}

M. Bonniaud

Commissariat a L'Énergie Atomique Centre de Marcoule

Boite Postale 170

30200 Bagnols-sur-Ceze

FRANCE

M. Faugeras

Commisariat a L'Énergie Atomique

Centre de Marcoule

Boite Postale 170

30200 Bagnols-sur-Ceze

FRANCE 
No. of

Copies

Bundesministerium für Forschung
und Technologie
Postf. 200706
5300 Bonn 2
GERMANY

Hans W. Levi

Hahn-Meitner-Institut

für Kernforschung

G] ienicker Strasse 100

1000 Berlin 39

GERMANY

Center for Atomic Energy

Documentation (ZAED)

Attn: Dr. Bell

P. 0. Box 3640

$7500 \mathrm{Kar} 7 \mathrm{sruhe}$

GERMANY

H. Krause

Kernforschungszentrum Karlsruhe $\mathrm{GmbH}$ (KfK)

Postfach 3640

D7500 Karlsruhe

GERMANY

N. S. Sunder Rajan

Bhabha Atomic Research Centre

Waste Treatment Division

Trombay, Bombay, 400085 INDIA

\section{ONSITE}

6 DOE Richland Operations Office

P. A. Craig

0. J. Elgert

H. E. Ransom

J. J. Schreiber

M. W. Shupe

M. J. Zamorski

11 Rockwell Hanford Operations

H. Babad

L. C. Brown
No. of

Copies
R. A. Deju
R. J. Gimera
D. R. Gustavson
E. J. Kosiancic
C. M. Manry
I. E. Reep
J. H. Roecker
D. D. Wodrich
File Copy
Exxon

S. J. Beard

UNC United Nuclear Industries

T. E. Dabrowski

Westinghouse Hanford Company

A. G. Blasewitz

134 Pacific Northwest Laboratory

R. P. Allen/H. W. Arrowsmith

D. G. Atteridge

N. E. Ballou

S. Begej

A. Brandstetter

R. L. Brodzinski

L. L. Burger

D. B. Cearlock

T. D. Chikalla

M. O. Cloninger

S. D. Dahlgren

R. L. Dillon

P. G. Doctor

F. H. Dove

H. Drucker

C. E. Elderkin

J. R. Eliason

E. A. Eschbach

J. W. Finnigan

B. Francis (10)

J. A. Franz

H. T. Fullam

J. J. Fuquay 
No. of

Copies

G. W. Gee

R. W. Goles

B. Griggs

C. R. Hann

H. Harty

A. J. Haverfield/W. R. Wiley

O. F. Hill

E. R. Irish

J. H. Jarrett

A. B. Johnson, Jr. (50)

R. S. Kemper

M. R. Kreiter

L. T. Lakey

T. M. Lambright

J. M. Latkovich

R. C. Li ikala

R. P. Marshall

J. L. McEl roy

R. W. McKee

I. C. Nelson

R. D. Nelson

J. M. Nielsen/R. W. Perkins

R. E. Nightingale

D. E. Olesen

N. J. 01 sen

C. R. Palmer

B. J. Phillips

A. M. Platt (2)

J. A. Powell

J. V. Robinson

W. A. Ross

J. M. Rus in

D. W. Shannon

A. M. Sutey

G. L. Tingey

C. M. Unruh

H. H. Van Tuyl

R. E. Westerman (5)

E. J. Wheelright

L. D. Williams

W. K. Winegardner

Technical Information (5)

Publishing Coordination 